\title{
ÉTICA, DISCURSO E SAÚDE: \\ UM OLHAR DE SI E DO OUTRO NA MÍDIA EM PAPEL
}

LIVIA MARIA PEDALINI

Tese apresentada na área de concentração de Serviços de Saúde da Faculdade de Saúde Pública para obtenção do grau de doutor

Área de concentração: Serviços de Saúde

ORIENTADOR: PROF. DR. PAULO ANTONIO DE CARVALHO FORTES

São Paulo

2003 
4402612003 doe

Autorizo, exclusivamente para fins acadêmicos e científicos, a reprodução total ou parcial desta tese, por processos fotocopiadores.

Assinatura:

Data: 
A trajetória de meu doutorado é longa, ou melhor, muito mais longa do que a minha pressa em concluir estudos e investigações.

Em 1988 vim para a Faculdade de Saúde Pública para tornar-me sanitarista. No mesmo ano passei no exame de pós-graduação e não pude iniciar o meu mestrado, pois naquela ocasião o número de alunos excedia ao número de orientadores.

Isto propiciou que eu me aproximasse de outros campos de investigação, dentre eles o Direito Sanitário, área em que me especializei e apresentei dissertação de mestrado e a Ética em Saúde cativada pelo meu orientador e paciente amigo Prof. Dr. Paulo Antonio de Carvalho Fortes.

No meu percurso acadêmico, outros professores e autores construíram meu conhecimento incentivando idéias e provocando reflexões. A minha banca examinadora é a representação do meu apreço pessoal a todos eles: Profa. Fabiola Zioni, Prof. Fernando Lefèvre, Prof. José Eduardo de Siqueira e Profa. Maria de Fátima Prado Fernandes.

Mas, como todo texto tem um contexto, uma infindável e inumerável lista de nomes de pessoas presentes e ausentes me acompanha.

Minha prática cotidiana no Hospital da Clinicas como fonoaudióloga, o convivio com os outros- os usuários do serviço, incentivou meus estudos nesta área e o amparo do Prof. Dr. Aroldo Miniti e colegas de trabalho permitiu que eu ganhasse mais algumas horas em meus momentos de análise e escrita deste trabalho.

Do apoio de meus muitos amigos, das várias Marílias que me habitam - Marilia de Queiroz Telles companheira de discussões comunicativas ardorosas e ardentes e Marilia de CastroTorres-Fernandes pela escrita em inglês.

$\mathrm{Na}$ minha casa os eternos formadores de minha identidade, meu pai e mãe e minha irmã, o outro lado da saúde.

Na tese, meus escrevinhadores leitores dos jornais.

Enfim ....... todos os que se sabem presentes.

Grazie mille, tante grazie 
O estudo, fundamentado na perspectiva dos estádios morais segundo a lógica do desenvolvimento de Jürgen Habermas, averigua a identidade da ética do discurso nas questões de saúde.

Através de pesquisa qualitativa, desenvolve análise sistemática e comparativa de artigos e matérias da redação e cartas do espaço reservado para os leitores, na mídia em papel em dois jornais paulistanos: "Folha de São Paulo" e "O Estado de São Paulo", para o tema "Ética em Saúde", no período de 1996/2001 com o quadro dos níveis de interação, perspectivas sociais e estádios morais de Habermas.

Os resultados apontam que a proposta de inserir a ética do discurso nas atuais discussões sobre a ética em saúde parece promissora para a descrição de representações morais e éticas nos diversos estágios de desenvolvimento humano e sociocultural, ou seja, nas diferentes formas de vida e, nesses termos, nas suas condições de realização.

Descritores: Ética em saúde. Ética do discurso. Princípios. Direitos humanos. Teoria da Comunicação. Agir comunicativo. 
This study seeks to identify the discourse ethics in health issues, regarding the perspective of moral stages as per Jürgen Habermas's logic of development.

Throughout a qualitative research, a systematic and comparative analysis has been carried out of articles, editorials and readers' letters concerning the "Health Ethics" theme, published in two local newspapers ("Folha de São Paulo" and "O Estado de São Paulo") between 1996 and 2001, in the frame of Habermas's levels of interaction, social perspectives and moral stages.

The results indicate that the proposed insertion of discourse ethics in contemporary discussions on health ethics seems promising for the description of moral and ethic representations in the various stages of human, social and cultural development, what is to say, in the different ways of life and thus in their conditions of being applied.

Key words: Health Ethics. Discourse Ethics. Principles. Human Rights. Communication Theory. Communicative action. 
I. INTRODUÇÃO _ _ 1

II. DELIMITAÇÃO DO OBJETO __ ${ }^{6}$

III. REFERENCIAL TEÓRICO__ 12

Habermas e seu programa teórico _ 12

Habermas o ator 12

Habermas e a esfera pública___ 14

Habermas e o paradigma da comunicação _ـ 20

Habermas e a Ética Do Discurso ___ 28

IV. PROCEDIMENTOS METODOLÓGICOS _ 38

V. RESULTADOS

0 aborto _ 46

as drogas __ 76

a eutanásia — 106

a doação presumida de órgãos _ـ 109

a clonagem 122

a dupla porta 126

o plano de saúde__ 129

VI. DISCUSSÄO _ 139

o aborto _ 141

as drogas _ـ 147

a eutanásia —_ 150

a doação

a clonagem 152

a dupla porta _ 153

o plano de saúde___ 154

VII. CONSIDERAÇÕES _ 157

REFERENCLAS BIBLIOGRÁFICAS_ 160 


\section{INTRODUÇÃO}

"Conta a história de náufragos à deriva: sem comida, decidiram matar e comer os moribundos; os aleijados depois; e, aí, criancinhas indefesas. Queriam se salvar. Foram-se comendo uns aos outros, até que, na jangada, sobrou um único sobrevivente. Quase morto de fome, começou a comer a si mesmo, primeiro pelas partes dispensáveis de seu corpo: dedos e braço esquerdo, a perna do mesmo lado. E acabou por comer os intestinos, já que não tinha encontrado nada de mais substancioso e nutritivo nem na cabeça nem no coração, órgãos inúteis!"

A introdução da fábula da jangada da Medusa caracteriza um repto, pois sua leitura é provocadora do eu como personagem desta ficção e de como eu agiria se vivesse situação semelhante. Ou seja, de imediato, tornamos presente a experiência dada e vivemos a conduta tomada pelos náufragos de modo unitário, unilateral e unidirecional contrapondo-a com os preceitos em nós anteriormente incorporados. É dessa forma que também observamos nossos atos na vida prática para decidir como atuar em uma dada situação. Intuitivamente racionalizamos fatos, remetemos à analise de juízo de preceitos anteriormente incorporados e buscamos respostas monológicas do tipo sim ou não. A decisão pode ser alcançada e justificada em uma relação meio e fim estabelecendo-se considerações metafísicas com fins à vida boa e ao reino dos céus, ou racionais nos supostos de normas positivas que podem ter um caráter utilitário ou equânime, impostas coercitivamente ou refletidas dialogicamente.

Portanto, todo o agir humano norteia-se a partir do que denominamos a ética. Ela nos fornece princípios, valores e normas que aplicamos nas diversas situações de vida apontando o caminho a ser tomado em uma ou outra decisão.

Isto pressupõe uma interação comunicativa. $O$ agente pode ser envolvido alternadamente como um falante, um destinatário e como uma pessoa presente e ter também perspectivas sociais diferenciadas com as quais se relaciona com o meio.

Simultaneamente almeja-se tomar atitudes as mais harmônicas e agir em vista de um objetivo que pressupõe a aceitação de todos os envolvidos, ou seja, que tenha conexão com os interesses e objetivos das pessoas envolvidas nesta interação. 
Este trabalho visa estudar a identidade da ética do discurso nas questões de saúde com a finalidade de conhecer o agir ético em algumas situações que envolvem a saúde humana, pois de igual maneira, temos que nos posicionar frente a dilemas de conflitos dentro da prática tradicional em saúde. Esse comportamento ético não pode ser meramente relativizado através da singularidade do conjunto de valores e objetivos morais de cada pessoa, pois ficariamos eternamente discutindo e acreditando em verdades próprias - dois indivíduos particulares vendo a si mesmo e o outro mas não o sistema de relações existentes entre eles. Faz-se necessário incorporar a compreensão de um mundo social ou de um mundo de pensamentos e experiências mutuamente compartidas.

Ainda é necessário lembrar que esta área vem sendo abalada e mesmo sufocada pela velocidade dos avanços tecnológicos contemporâneos gerando uma quase-fábula, por exemplo, no dia de um médico plantonista ao decidir qual vida salvar entre três acidentados quando da existência de um único leito em unidade terapia intensiva (UTI), para na seqüência, refletir até que momento deve-se prolongar a vida de um paciente e ainda, caso venha ocorrer morte encefálica, quando iniciar as tramitações necessárias para aproveitamento de órgãos em transplantes, ampliando para o espaço familiar a decisão em fazer a doação.

Parto da proposição de que é essencial estabelecer-se um critério que, além de satisfazer melhor a amplitude de resoluções das novas questões inseridas nessa área, permita uma maior compreensão do outro incluindo-o no processo de reflexão e tomada de decisão. Para tal é necessário lançar mão da ciência filosófica e seus paradigmas e aplicar critérios de fundamentação e é isso que a Bioética, aqui entendida como uma área de reflexão, vem tentando fazer nos últimos anos ao aplicar os conhecimentos, sejam dos clássicos ou neo-clássicos platônicos, aristotélicos, kantianos ou hegelianos. Assim, observa-se desde o paternalismo médico com o enfoque dado sobre o bem do paciente, passando a considerar importante o princípio de autonomia do indivíduo que se amplia com o principialismo e seus quatro princípios básicos - beneficência, não maleficência, autonomia e justiça e se multiplica ao particularizar em um ou outro aspecto latente, nas éticas denominadas liberais, das virtudes, feminista, naturalista, personalista, contratualista, hermenêutica, libertária e ambientalista. ${ }^{1}$ Assim, são referenciados desde pensadores como

\footnotetext{
'sobre o tema ler ANJOS MF. Bioética: Abrangência e Dinamismo. O Mundo da Saúde 1997 21(1).
} 
Thomas Hobbes, Adam Smith, John Locke até a atualidade com John Rawls e Ronald Dworkin.

A ética do discurso ainda não foi transposta para o núcleo de discussões da ética em saúde e quero torná-la objeto deste estudo. Das diversas posições filosóficas da escola frankfurtiana, ela se configurou como um dos ramos importantes a partir dos anos setenta.

O termo "ética do discurso" foi introduzido pelos filósofos Karl-Otto Apel e seu discípulo Jürgen Habermas (cf. APEL 1998, p. 8), ambos representantes das denominadas "éticas kantianas". Habermas explica

"De ahí que K.O.Apel y yo hayamos propuesto entender la argumentación moral misma como el procedimiento adecuado de formación de una voluntad racional. EI examen de pretensiones de validez hipotéticas representa tal procedimiento, porque quien quiera argumentar seriamente ha de estribar en las suposiciones idealizadoras que comporta una forma de comunicación tan exigente como es el discurso práctico. Todo participante en una práctica argumentativa tiene que suponer pragmáticamente que en principio todos cuantos pudieran verse afectados podrían participar como iguales y libres en una búsqueda cooperativa de la verdad en que la única coerción que puede ejercerse es la coerción sin coerciones que ejercen los buenos argumentos "(HABERMAS 1991, p. 162).

Habermas sugere que Kant parte de um conceito estrito de moral e atua conforme aquela máxima que com o tempo pode se converter em uma lei universal, enquanto a ética discursiva estabelece que somente podem pretender validez aquelas normas que pudessem dar conta com o consentimento de todos os afetados como participantes no discurso prático. Para Habermas o discurso prático é um procedimento que não serve para a produção de normas justificadoras e sim ao exame de validez de normas já existentes, porém, que ao terem se tornado problemáticas são abordadas em atitude hipotética (cf. HABERMAS 1991, p. 72).

Além disso, na medida em que o discurso prático se distancia da primeira pessoa numa reflexão dentro dos limites da formação individual da vontade, insere-se na esfera pública em uma argumentação coletiva que impõe a publicidade do discurso. Então, o entendimento mútuo entre as partes, cujas vontades e interesses chocam entre si, transporta-se para os procedimentos institucionalizados e pressupostos comunicativos das 
argumentações e negociações que sejam necessárias para atingir êxito. Isso só pode acontecer mediante a existência de grupos organizados e de uma mídia que permita esta interlocução levando a formação da opinião pública, pois

"Las desencadenadas libertades comunicativas de los ciudadanos han de hacerse efectivas, como Rawls dice con Kant, en el uso público de la razón". Pero la "influencia" de las opiniones que compitemn en el espacio público político y el poder comunicativo formado conforme a los procedimientos democráticos en el horizonte de ese espacio público sólo pondrán tornarse efectivos si, sin intenciones de conquistarlo, operan sobre el poder administrativo para programarlo y controlarlo" (HABERMAS 2000b, p. 153).

Assim é inevitável analisar e entender dentro do contexto comunicativo, qual a qualidade desta opinião: manifestada por manipulação ou através da crítica, afastando a existência de formas obrigatórias de consenso nas diversas esferas envolvidas.

A mídia - no caso em apreço, a mídia em papel, será o instrumento de observação e avaliação da argumentação das pessoas na busca de consenso sobre questões éticas.

Por fim, a abordagem da teoria da ética do discurso propicia mais um fundamento auxiliar para as reflexões geradas dos múltiplos desafios que o mundo contemporâneo enfrenta. A meu ver, isso só pode ocorrer na condição de que o papel do outro seja modificado de maneira que formas de vida individuais possam desencadear uma formação de vontade e responsabilidade coletiva incluindo o outro com igual respeito $\mathrm{e}$ solidariedade.

"El igual respeto de cada cual no compreende al similar, sino que abarca a la persona del otro o de los otros en su alteridad. $\mathrm{Y}$ ese solidario hacerse responsable del otro como uno de nosotros se refiere al flexible "nosotros" de una comunidad que se opone a todo lo sustancial y que amplía cada vez más sus porosos límites. Esta comunidad moral se constituye tan sólo sobre la base de la idea negativa de la eliminación de la discriminación y del sufrimiento, así como de la incorporación de lo marginado y del marginado en una consideración recíproca. Esta comunidad, concebida de modo constructivista, no es un colectivo que obligue a uniformizados miembros a afirmar su proprio modo de ser. Inclusión no significa aquí incorporación en lo 
proprio y exclusión de lo ajeno. La "inclusión del otro" indica, más bien, que los límites de la comunidad están abiertos para todos, y precisamente también para aquellos que son extraños para los otros y quieren continuar siendo extraños" (HABERMAS 1999, p. 23-24).

Ademais, retornando à fábula inicial e tomando o exemplo do risco egocêntrico de provável fim autofágico não sofrer o perigo de

"Chorar a lágrima que me jogaram no rosto, sorrir o sorriso que me esculpiram na face, como pedra".

${ }^{2}$ fragmento de texto do dramaturgo Augusto Boal, Teatro como arte marcial, publicado na Folha de São Paulo, São Paulo, 29 de dezembro de 2000. Disponível em: <URL:http://www.uol.com.brl. [2000 dez 30]. 


\section{DELIMITAÇÃO DO OBJETO}

O descompasso dado pelo acelerado progresso tecnológico resulta em conflito para o desenvolvimento do homem sob os aspectos sociais, políticos e econômicos. Tanto as questões relacionadas à participação social como as atenções para os temas éticos aglutinam dificuldades em processos de decisão. Os procedimentos e experimentos nessa área co-habitam em um espaço crítico. No campo da ética da saúde, onde os limites vão além do início da vida e a morte, - que apropriadamente aluz Ronald Dworkin ao tratar da discussão sobre a liberdade de aborto e eutanásia: "This is a book about death and life, and about the bearing of each on the other" (DWORKIN 1994, p. ix) - as reflexões tornam-se ainda mais desassossegadas dado que o próprio desenvolvimento tecnológico obriga-nos a rever conceitos de vida e morte de maneira constante. A exemplo, a recente publicação do artigo de James J. Hughes, "O futuro da morte", escrito para o "Journal of Evolution and Technology", ${ }^{3}$ trata da tecnologia problematizando a morte ao discorrer sobre o congelamento de corpos e outros avanços da pesquisa sobre a vida e sua suspensão, refletindo a imposição de tais questões em um novo debate ético e jurídico, pois o conceito de morte pode deixar de ser concebido como um evento para se tornar um processo de reversão, dado a possibilidade de, na presença de não tratamento de doença fatal, o indivíduo vir a optar por ser congelado até que novas curas sejam descobertas.

Esta tensão ainda coexiste com o crescente pluralismo de culturas das sociedades modernas e as reflexões éticas para atos decisórios agregam para si uma maior complexidade perante o enfrentamento das tradições culturais e seus múltiplos princípios morais, éticos e religiosos, obstruindo o processo de integração social para posições de decisões autônomas ou coletivas, dificultando o estabelecer da relação direito/obrigação para, por exemplo, a decisão pela eutanásia como direito em conflito especialmente com princípios religiosos, ou a obrigação de aceitar os princípios das regulamentações de políticas estabelecidas.

\footnotetext{
${ }^{3}$ Folha de São Paulo, São Paulo, 04 de novembro de 2001. Disponível em:<URL: http://www.uol.com.br/. [2001 nov 16].
} 
No Brasil a produção teórica sobre ética tem aumentado consideravelmente. Até pouco tempo, disciplinas de ética ministradas nos cursos da área da saúde conservavam em seus conteúdos temas próprios e normas de conduta de cada formação. Os conselhos profissionais respeitavam, em sua maioria, o juramento hipocrático e códigos paternalistas e unilaterais no sentido de visar somente salvaguardar a ação dos profissionais. Estes estabeleciam somente seus direitos e deveres e, raramente, uma preocupação efetiva com o paciente e seus direitos enquanto tal.

Mas, a partir da década de 80 , com o final do período ditatorial e com a nova carta constitucional, outros caminhos de discussão e estratégia em saúde foram abertos. $O$ cidadão ganhou diversos instrumentos de defesa e participação de forma a provocar mudanças no pensamento ético vigente, incluindo mais um ator nos processos de decisão de conflitos éticos (cf. FORTES 1997, p. 72-73; 1998, p. 20-21).

Em paralelo, existe mundialmente, a partir do pós-guerra, uma forte preocupação em assegurar o respeito ao espaço ético nas pesquisas que envolvem seres humanos. $O$ Código de Nuremberg e a Declaração de Helsinque, estabelecidos em 1947 e 1964 , respectivamente, são confrontados no espaço de discussão dos conflitos gerados pelos avanços tecnológicos e novas formulações de mecanismos de controle estabelecidos protocolos de pesquisas e a criação de comitês externos que possam ajuizar o respeito ético ao ser humano envolvido. ${ }^{4}$

Em 1988 O Conselho Nacional de Saúde - CNS aprovou, para o Brasil, as normas nacionais sobre ética na pesquisa em seres humanos. ${ }^{5}$ Esta iniciativa refletia as primeiras preocupações em estabelecer regulamentos mínimos para pesquisa em saúde, pois o acelerado desenvolvimento biotecnológico começava a manifestar a presença de eventos inusitados que o pensar ético não conseguia, de pronto, responder. Mais tarde atendeu às diretrizes internacionais para pesquisa biomédica envolvendo seres humanos que o Conselho das Organizações Internacionais de Ciência Médicas da Organização Mundial de Saúde preparou em 1993 - todas as pesquisas envolvendo seres humanos deviam ser sujeitas à revisão e aprovação de um ou mais comitês independentes recomendando-se que

\footnotetext{
4 exemplo, a Associação Médica, Tóquio - 1975, estabelece que pesquisas devem ser apresentadas em protocolos formulados detalhadamente para revisão de comitês nacionais independentes aos nelas envolvidos.

${ }^{5}$ Resolução CNS n. ${ }^{\circ} 1 / 88$.
} 
os mesmos apresentem uma composição multidisciplinar para melhor exame dos casos apresentados. ${ }^{6}$

Por um período de sete anos estas normas foram pouco aplicadas e na década de 90 foi designado pelo Ministério da Saúde/CNS um Grupo de Trabalho para revisão e atualização. Esse grupo interdisciplinar desenvolveu criteriosa tarefa que consistiu na divulgação de informações; consulta à cientistas, entidades de pesquisa e à sociedade civil; revisão da literatura e da legislação brasileira, de diversos países e de organismos internacionais; discussão e debates externos (cf. NUNES 1996, p. 3) e elaborou novas normas - as Diretrizes e Normas Regulamentadoras de pesquisas em Seres Humanos -, que foram aprovadas em 10 de outubro de 1996 pelo Conselho Nacional de Saúde através da Resolução CNS nº.196/96. Nessa ocasião, foi criada o Comissão Nacional de Ética em Pesquisa, de natureza consultiva, deliberativa (no âmbito da emissão de pareceres sobre protocolos de pesquisas), normativa (no âmbito propositivo de Resoluções do CNS), educativa, autônoma e vinculada ao Conselho Nacional de Saúde - CNS (art. $1^{\circ}, \operatorname{CS~} n^{\circ}$ 196/96). Portanto, para garantir o proposto, a resolução inevitavelmente exigiu o estabelecimento de comitês de Ética em Pesquisa nas diversas instituições que desenvolviam investigação em seres humanos.

Essa nova experiência colocou em prática os princípios básicos da Bioética autonomia, beneficência, não-maleficência e justiça - que obrigatoriamente resultaram em considerações sobre os direitos da pessoa humana, como a exigência do consentimento livre e esclarecido, de cuidados especiais com a metodologia aplicada e a adequação de procedimentos.

Reflexos das discussões sobre pesquisas em seres humanos foram sentidos tanto na prática clínica cotidiana - com a exigência do consentimento esclarecido e a resultante ampliação do princípio da autonomia, como na reflexão das ações de organização e planejamento da saúde para o defrontamento de decisões quanto a serviços e alocações de recursos. Todavia, a substância deste agir ético, quer no individual quer no coletivo, norteia-se tradicionalmente em uma ética religiosa ou kantiana, pautada pelo dever ser. $\mathrm{O}$ que decorre daí são atitudes éticas objetivas, ou seja, observa-se a ação frente às

\footnotetext{
${ }^{6}$ o artigo Ética em Pesquisa: uma perspectiva brasileira de Leonard M. Martin (Martin 2002, p.85-100) faz uma retrospectiva muito interessante sobre $o$ assunto.
} 
proposições e sentimentos do ponto de vista interno do participante. Refiro-me aqui a um modelo de ética formal positivista que está fundada em normas de ação individual que pressupõe um ideal objetivo - a felicidade ou a vida eterna - determinada comum a todos os homens.

No cotidiano ligado à área de saúde, as discussões de questões práticas extrapolam o horizonte das éticas formalistas. A exemplo, a revisão conceitual dos termos vida e morte coloca em discussão dilemas que excedem os limites de proposições normativas analisadas como verdadeiras ou falsas em seu sentido estrito seja como uma verdade moral, uma máxima ou um imperativo. Igualmente, quando um paciente frente ao seu médico pergunta sobre o que deve fazer para curar-se, esta pergunta passa a ser discutida também com o que devo fazer do profissional de saúde orientado na possibilidade de escolha e da autonomia de decisão e assim com uma conseqüente quebra de relação de poder unilateral. Ou, transportado para processos de decisão em grupos de cidadãos, o mesmo pode ocorrer: frente à demanda por um acesso ao tratamento mais avançado, o gerenciador e/ou administrador de saúde pode igualmente retornar o devo fazer provocando em grupos a decisão de procedimentos na multiplicidade de suas vozes - o que devemos fazer. Ambos exemplos comportam-se dialogicamente e não monologicamente como a já referida formalidade permite, e insuficiente para ações de conseqüências coletivas.

Uma rápida leitura da bibliografia sobre este assunto é suficiente para demonstrar os diversos princípios filosóficos aplicados para embasar as argumentações nos processos de decisão quanto a adequação ou não das intervenções e/ou investigações científicas. Esses princípios, pinçados dos clássicos do pensamento filosófico e empregados na argumentação dos diversos autores abrandam algumas situações de conflito específicas da área de saúde, não passando, porém, a compor um programa ético que atenda o avanço tecnológico que essa área vivencia nem a multiplicidade de realidades sociais do já referido quadro social brasileiro. ${ }^{7}$

\footnotetext{
${ }^{7}$ A exemplo, tomando-se as publicações da Revista Bioética - Conselho Federal de Medicina encontramos artigos de temas filosóficos gerais: "Breve panorama histórico da ética" (SILVA FL 1993); "Fundamentação antropológica da bioética" (NEVES MCP 1996); "Saúde pública, bioética e equidade" (OSELKA G, GARRAFA V, DINIZ D. 1997); "O contexto histórico, semântico e filosófico do princípio de autonomia" (SEGRE M, SILVA FL, SCHRAMM FR 1998); ou por temas éticos em discussão: "O mercado de estruturas humanas" (GARRAFA V. 1993); "Implicações filosóficas na reflexão, discurso e ação dos comitês de ética" (BERTOMEU MJ. 1995); "Bioética como ética aplicada e genética" (CLOTET J. 1997). "A questão da autonomia e a bioética. "(FERRAZ FC. 2001; 9(1):73-98).
} 
$\mathrm{Na}$ realidade este exame tenciona explicar a amplitude de situações de conflitos éticos e alcançar uma base teórica mais abrangente. Em especial no caso brasileiro, temos através da influência das discussões bioéticas duas linhas básicas teóricas: uma americana, de cunho utilitarista, a teoria principialista já referida, e uma de origem européia, ${ }^{8}$ mais teórica e de caráter humanista, baseada nos direitos humanos e que se preocupa com a fundamentação e os procedimentos para solucionar os casos éticos. O que se pretende é encontrar bases de conhecimento para uma realidade latino americana que vive tanto situações emergentes como persistentes, isto é, tem que resolver dilemas criados pelo acelerado desenvolvimento científico e tecnológico como os relacionados à exclusão social, discriminação quanto a genêro, falta de eqüidade na alocação de recursos e distribuição de recursos sanitários, aborto, eutanásia (cf. GARRAFA 1998, p. 99-100; 2002. p. 7).

Meu estudo tem como base os fundamentos da teoria do conhecimento de Jürgen Habermas. A escolha desta fundamentação teórica deve-se a possibilidade de abrangência de situações que a teoria pode responder. Sua filosofia orienta-se em empreender a articulação de uma teoria das sociedades contemporâneas que se inicia com a teoria da ação comunicativa onde a ação social nos planos de diversos agentes são coordenados através de ações de fala, uma teoria da sociedade concebida com intenção prática (cf. HABERMAS 1990, p. 13).

O paradigma da comunicação tem como primeiro pressuposto a verdade como uma pretensão de validade, isto é, os questionamentos levam a resultados que representam um passo para um trajeto infinito de investigação. ${ }^{9}$ Outro é o de que a democracia é parte necessária do processo científico aqui entendida como forma institucionalmente garantida de uma comunicação geral e pública, que se ocupa de questões práticas de como os homens querem e podem conviver sob condições objetivas de uma capacidade de disposições ampliadas (cf. DEMO 1994, p. 23-24).

\footnotetext{
${ }^{8}$ Teoria fortemente calcada na tradição da ética européia, e então marcada pela idéia de virtude e caráter. Caracteriza-se por ser mais pluralista estendendo suas reflexões para as macro questões. Assim, a preocupação com a dimensão social do ser humano prioriza os direitos individuais no que diz respeito a justiça e eqüidade (cf. PESSINI L. e BARCHIFONTAINE CP. 1988, p. 88-91).

${ }^{9}$ Como coloca Pedro Demo em seu livro "Pesquisa e construção de conhecimento: metodologia científica no caminho de Habermas" (DEMO 1994, p. 22): “ Da mesma forma, poderíamos dizer que a ciência é uma pretensão de conhecimento, dentro de um processo infindável de busca e pesquisa. Não existe produto final. A verdade não é propriedade de ninguém e pode sempre ser rediscutida naquilo que depende de consenso para ser válida. A validade não prescinde da comunicação".
} 
Ao desenvolver seus escritos sobre filosofia moral, Habermas não constrói uma ética privatista firmada em um moralismo abstrato nem desenvolve uma teoria moral diretamente normativa, ao contrário, no lugar de pretender dizer ao agente moral o que ele deve fazer, o filósofo quer dar condições ao agente para interpretar o que ele já conhece intuitivamente.

"Em minha concepção, o filósofo deve explicar o ponto de vista moral, fundamentando, da melhor forma possivel, a pretensão de universalidade desta explicação, mostrando porque ela não reflete meramente intuições morais do componente médio, masculino, da classe média da moderna sociedade ocidental" (HABERMAS 1987, p. 84). ${ }^{10}$

Ademais, Habermas está preocupado em adequar seu pensamento ao contexto atual que divide duas idéias fortes: o pluralismo cultural e a globalização sem perder o reconhecimento dos indivíduos e grupos sociais, ou seja, trabalhar com a idéia de harmonizar as estratificações sociais e não homogeneizá-las que tão bem se aplica para as situações éticas em saúde contemporâneas.

\footnotetext{
${ }^{10}$ Habermas trabalha o princípio categórico de Kant fazendo uma derivação do princípio (U) que determina uma fórmula (D): toda norma válida teria de encontrar o assentimento de todos os afetados se estes participassem em um discurso prático. Habermas sugere que Kant parte de um conceito estrito de moral e atua conforme aquela máxima que com o tempo pode se converter em uma lei universal, enquanto a ética discursiva estabelece que somente podem pretender validez aquelas normas que pudessem dar conta com o consentimento de todos os afetados como participantes no discurso prático. Para Habermas o discurso prático é um procedimento que não serve para a produção de normas justificadoras e sim ao exame de validez de normas já existentes, porém, que ao terem se tornado problemáticas são abordadas em atitude hipotética (cf. HABERMAS 1991, p. 72.)
} 


\section{REFERENCIAL TEÓRICO}

\section{Habermas e seu programa teórico}

Abordar a obra de Habermas constitui-se um trabalho árduo e, não caberia tampouco é pretensão - desenvolver aqui um estudo detalhado. Ainda assim, para entendimento da ética do discurso, faz-se necessário percorrer seus estudos e destacar alguns conceitos fundamentais. Neste capítulo apresento uma breve biografia do autor, um resumo de algumas de suas obras relevantes, de seus conceitos fundamentais e da ética do discurso.

\section{Habermas o ator}

Jürgen Habermas é um dos principais nomes da filosofia da atualidade. Nascido em Düsseldorf em 18 de junho de 1929, estudou filosofia, história, psicologia e literatura alemã nas universidades de Göttingen, Zurique e Bonn. Esta pluriformação redundou em um referencial teórico bastante abrangente na construção de seu programa teórico.

Não obstante ter nascido no período da fundação do Institut für Sozialforschugng" (Instituto de Pesquisa Social) ligado à Universidade de Frankfurt, é considerado por muitos o representante da Escola de Frankfurt ou o representante de segunda geração dessa escola. ${ }^{12}$ E, apesar de aluno de Theodor Adorno e Max Horkheimer, ${ }^{13}$ na realidade a sua aproximação com o pensamento frankfurtiano se dá a partir de seu vínculo com o Instituto entre 1964/1971, período em que, em resposta aos movimentos estudantis, toda a teoria crítica e os pensadores da escola foram revistos. ${ }^{14}$

\footnotetext{
${ }^{11}$ Instituído por Felix Weil em 1923, na República Alemã de Weimar do pós primeira guerra mundial, como um centro interdisciplinar de estudos em política econômica e produção cultural.

${ }^{12}$ Habermas contribuiu muito para o enriquecimento teórico da Escola de Frankfurt. Ele se manteve fiel ao projeto da escola, que é uma teoria social crítica com intenções práticas, bem como ao seu programa caracterizado por uma pesquisa interdisciplinar, que procura estabelecer uma nova relação entre a filosofia e as ciências humanas. Assim ele retoma o caminho de uma teoria crítica da sociedade, com a mudança de paradigma de razão instrumental para a razão comunicativa (Cf. ANDRADE, C.J. 1998 p.109-124)

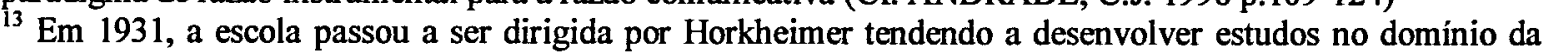
filosofia, cultura e mídia.

${ }^{14}$ Segundo biografia elaborada por Flávio Beno Siebeneichler em seu livro "Jürgen Habermas: razão comunicativa e emancipação", Habermas foi um dos mentores da revolução estudantil de maio 1968 assim como um de seus críticos mais exigentes. Em 1971 "após acalorados debates com os estudantes, Habermas deu, por assim dizer, as costas à universidade, levado por seu crescente ceticismo com relação ao potencial de
} 
A escola de Frankfurt foi fundada por um grupo de marxistas vinculados à esquerda alemã, nomes como Theodor Adorno (1903-1969), Max Horkheimer ( 1895-1973) Herbet Marcuse (1898-1979), Walther Benjamim (1803-1940), Erich Fromm (1900-1980), que desenvolveram uma teoria crítica ${ }^{15}$ da sociedade em oposição ao cientificismo positivista a redução de todo conhecimento a um modelo de ciências empíricas e ao domínio da técnica como se a razão não tivesse outros aspectos e campos de atuação. Conforme GEUSS, a escola e seus participantes tinha em comum as seguintes teses:

“1) Teorias críticas têm posição especial como guias para a ação humana, visto que: a) elas visam produzir esclarecimento entre os agentes que as defendem, isto é, capacitando esses agentes a estipular quais são seus verdadeiros interesses; b) elas são inerentemente emancipatórias, isto é, elas libertam os agentes de um tipo de coerção que é, pelo menos parcialmente, auto-imposta, a auto-frustação da ação humana consciente;

2) Teorias críticas têm conteúdo cognitivo, isto é, são formas de conhecimento;

3) Teorias críticas diferem epistemologicamente de teorias em ciências naturais, de maneira essencial. As teorias em ciência natural são "objetificantes"; as teorias críticas são "reflexivas"” (GEUSS 1988, p. 8-9).

Em 1954 Habermas doutorou-se com a tese "O absoluto na História - um estudo sobre a filosofia das idades do mundo, de Schelling", época em que foi convidado pelo Institut a participar em um estudo sociológico sobre consciência política dos estudantes de Frankfurt onde, mais tarde, teve vinculação formal (1964-1971) ao assumir a cadeira de Horkheimer. Em sua aula inaugural traçou pela primeira vez as perspectivas sistemáticas de sua teoria ${ }^{16}$, mais tarde publicadas no livro "Conhecimento e Interesse" (HABERMAS 1987).

inovação e de transformação social do movimento estudantil" (SIEBENEICHLER 1994, p.180).

${ }^{15}$ sobre o assunto ver "Critical Theory and the Frankfurt University", entrevista de Habermas com Josef Früchtl (HABERMAS 1992, 211-227).

${ }_{16}$ tradução da conferência para o português, publicada na coleção "Os Pensadores" com o título "Conhecimento e Interesse", In: Textos escolhidos / Walther Benjamin, Max Horkeimer, Theodor W. Adorno, Jügen Habermas, traduções José Lino Grünnewald et al. $2^{\mathrm{a}}$ ed. São Paulo: Abril Cultural, 1983, p. 301-312; tradução da conferência para o espanhol, com o título "Conocimiento e interés", [1screen] disponivel em: http://usuarios.lycos.es/Cantemar/Conocimiento.html. Acesso em 29 de agosto de 2002. 
Em 1971, tornou-se diretor do Instituto Max Plank, Starnberg, lá permanecendo até 1981 quando retornou para as suas atividades na Universidade de Frankfurt.

\section{Habermas e a esfera pública}

O tema esfera pública foi tratado por Habermas em seu livro "Mudança estrutural da esfera pública". ${ }^{17}$ Como coloca no prefácio

“O modo de operar essa investigação é imposto pelas dificuldades específicas de seu objeto. Em primeiro lugar, a sua complexidade impede que ela se limite aos procedimentos específicos de uma única disciplina. A categoria "esfera pública" precisa ser, pelo contrário, explorada naquele vasto campo outrora tradicionalmente imputado à "política"; dentro dos limites de cada uma das disciplinas sociológicas tomadas isoladamente, o nosso objeto se dilui"' (HABERMAS 1984, p. 9).

Ele trabalha o tema sociológica e historicamente, em uma perspectiva analítica, delimitando assim, a "esfera pública burguesa", pois sustentava que o século XVIII foi crucial para o seu nascimento, em especial na França e Inglaterra, a partir de seus periódicos, círculos e cafés. O livro é uma extensa reflexão sobre a natureza da vida pública e sobre os modos de mudança na evolução histórica do Ocidente.

Este estudo, apesar das diversas críticas $^{18}$ recebidas (cf. THOMPSON 1996, p. 5-9; COSTA 1999, p. 99-100), ainda é referência para o entendimento das relações entre o espaço público e privado, opinião pública, evolução da categoria de cidadania e da configuração política construída a partir dela. Mais tarde, Habermas articulou as questões nele argumentadas com a sua teoria de ação comunicativa e a ética do discurso, colocando a discussão pública como única possibilidade de superar conflitos sociais, na busca de consensos que permitam o acordo e a cooperação apesar de divergências de opinião e

\footnotetext{
${ }^{17}$ A proposição original foi desenvolvida como tese apresentada para a livre docência de Habermas Strukturwandel der Öffentlichkeit. Untersuchungen zu einer Kategorie der bürgerlichen Gesellscha (História e crítica da opinião pública. A transformação estrutural da vida pública), em 1961.

${ }^{18} \mathrm{Em} 1989$ foi traduzido pela primeira vez para a língua inglesa em uma edição americana editada por Craig Calhoun (CALHOUN 1994). O livro reuniu quinze ensaios originados da conferência realizada para este lançamento e traz discussões sobre modelos filosóficos, história pública, comunicação pública terminando com as reflexões de Habermas em resposta a seus críticos. Das críticas importantes temos a de Geoff Eley que destaca a importância de outros movimentos sociais e políticos ingleses que não se desenvolveram em linhas similares da esfera pública burguesa ou Nancy Fraser quando discute o enfoque do caráter masculino da revolução burguesa, a questão de gênero e a marginalização das mulheres. Neste mesmo livro Habermas contra-argumenta, no último capítulo, que tanto as mulheres como os trabalhadores e camponeses foram, em sua maioria, excluídos da esfera pública burguesa e que com respeito às mulheres a exclusão teve uma significação relevante.
} 
consensos que permitam o acordo e a cooperação apesar de divergências de opinião e interesses. Como refere Margarita Boladeras Cucurella, Habermas considera a questão da opinião pública

(...) una pieza clave de sua propuesta de política deliberativa, una alternativa para superar los déficits democráticos de las políticas contemporáneas. Em Facticidade y validez (publicada en alemán en 1992) lleva a cabo una investigación sobre la relación en hechos sociales, normatividad y política democrática; el espacio público se presenta como el lugar de surgimiento de la opinion pública, que puede ser manipulada y deformada, pero que constituye el eje de la cohesión social, de la construcción y legitimación (o delegitimación) política. Las libertades individuales y políticas dependen de la dinámica que se suscite en dicho espacio público" (CUCURELLA 2001, p. 53).

O conceito de esfera pública refere-se a um espaço de nossa vida social, onde os cidadãos se reúnem para discutir assuntos de interesse geral e buscam persuadir uns aos outros através da argumentação racional e crítica e, assim, construir uma opinião pública que intermedeie o Estado e as necessidade dessa sociedade. Tal esfera pode ser vista a partir de diversos aspectos

"Desde el punto de vista de la teoría discursiva de la legitimidad democrática, la esfera pública ( $\mathrm{y}$ todos los derechos de comunicación $\mathrm{y}$ asociación) provee el único contexto en el que todos los interesados pueden participar en un plano de igualdad en las discusiones de normas y políticas en disputa. Desde esta perspectiva normativa, la formación de la voluntad colectiva ocurre vía la comunicación racional irrestricta en la que lo público civil deviene autoridad critica vis a vis la génesis del poder y la legitimidad de las normas. Desde el punto de vista de una teoría de la sociedad civil (democrática), la esfera pública representa el nivel en el que la integración legalmente regulada de grupos, asociaciones y movimientos puede recibir la necesaria ilustración concerniente a las políticas públicas e influenciar a la vez la formación de políticas mediante la tematización y el debate de asuntos de interés general. Finalmente, desde el punto de vista de la democracia parlamentaria, la apertura de cuerpos representativos a la esfera de lo público 
democrático, y es, en consecuencia, un elemento clave de su legitimidad democrática. Se supone que la esfera pública de representación política está abierta a la influencia de la sociedad civil - los temas, asuntos, debates y opinión pública debatidos y desarrollados en esta última deberían en principio figurar entre los temas considerados por la primera" (COHEN \& ARATO 1999, p. 39).

Habermas constrói o conceito de esfera pública burguesa argumentando sobre distinção dos termos público e privado e a idéia de publicidade. Parte da Grécia antiga tomando as idéias de esfera pólis- comum a todos os cidadãos livres e oikos- particular a cada indivíduo, ressaltando que a mesma não se restringe a um lugar. Para eles, o exercício da liberdade e da igualdade consiste na possibilidade da discussão e para pertencer a esse lugar como cidadãos, é necessário ter autonomia privada como senhores da casa.

"A esfera privada está ligada à casa não somente pelo nome (grego); possuir bens móveis e dispor de força de trabalho tampouco constituem substantivos de poder sobre a economia doméstica e a família, assim como às avessas, pobreza e não possuir escravos já seriam por si impecilhos no sentido de poder participar na pólis (...)" (HABERMAS 1984, p. 16).

O que Habermas quer dizer é que somente na esfera pública, na conversação dos cidadãos entre si, é que os fatos concretos se verbalizam e se configuram. Ali eles transitam como iguais entre iguais

“(...) na disputa dos pares entre si, os melhores se destacam e conquistam a sua essência: a imortalidade da fama" (HABERMAS 1984, p. 16).

O cidadão definido a partir do lugar e do patrimônio, tem direitos no âmbito público que são vedados aos que dependem dele.

Esta distinção entre o público e o privado, base da sociedade grega, persistiu até a Idade Média, mas já não tinha vínculo obrigatório. $O$ privado - a casa ${ }^{19}$ se contrapunha ao comum - a praça, o poço e ao estatal

\footnotetext{
${ }^{19}$ Apesar da casa ser o centro de todas as relações de dominação, a posição do senhor em nada se assemelha ao poder privado ao oiko-despostes (déspota) da antiga Grécia.
} 
"Não obstante, os atributos da soberania, como o selo de príncipe, não por acaso são chamados "públicos"; não por acaso o rei inglês goza de "publicness" - ou seja, aí existe uma representação pública da soberania"(HABERMAS 1984, p. 19).

e os reis mantinham esta denominação para identificar uma posição representativa de um poder superior, autoritário e absolutista.

"Esta representatividade pública não se constitui num setor social, numa esfera daquilo que é público; ela é pelo contrário, caso se possa ampliar o sentido do termo, algo como uma marca de status" (HABERMAS 1984, P. 1920).

Assim, o senhor feudal simboliza uma representação de poder superior que tem unicamente significado de corporificação de um atributo de pessoa e pelo tal neutro com respeito às relações de público e privado.

A situação se mantém até a transição dos séculos XVI - XVII, quando, com o início do desenvolvimento mercantilista e a crise reformista do cristianismo, modificações importantes de caráter político-econômico refletem mudanças gradativas nas estruturas de poder. Ao tempo que ocorre a ruptura do dogma público autoritário da igreja - autoridade divina; a criação de bancos e negócios monetários, com o domínio do privado na sociedade civil, não reconhece mais a autoridade do monarca e necessita de uma nova organização nas relações Estado e sociedade.

Paralelamente, dois sistemas de informação surgem: os correios ordinários ${ }^{20}$, que se tornam agências de notícias - sistema de informações pertencente às corporações profissionais, chancelarias urbanas de caráter interno e, portanto, sem a idéia de publicidade. Mais tarde, a imprensa periódica ${ }^{21}$ passou a integrar também as discussões sobre questões políticas e sociais. Deve-se somar aqui a importância das casas de café, surgidas na primeira década do século XVIII, espaço que passou a existir como verdadeiro centro de socialidade.

\footnotetext{
${ }^{20}$ Até então existia a troca de cartas comerciais que as associações comerciais organizaram e que partiam em determinados dias transformando estes centros comerciais também em centros de informação.

${ }^{21}$ Habermas admite a imprensa periódica como de importância particular para a mudança estrutural da esfera pública, pois ela vai transformar o caráter privado do correio e, mesmo o dos jornais manuscritos, em público no que ele denomina de esfera literária, ou seja, os períodicos criados inicialmente para crítica literária e cultural.
} 
Esse era o interesse tanto dos comerciantes como das autoridades que tornaram útil às suas intenções administrativas mas ainda sem o caráter de publicidade. Com o crescimento do capitalismo essas medidas administrativas se definem cada vez mais, o intercâmbio de mercadorias é formalmente regulamentado. Começam as trocas de matérias-primas por produtos acabados ou semi-acabados, surgindo uma estrutura de produção local, pois o comércio exterior agora ocupa as pessoas neste sistema levando a definição da regulamentação do modo de produção.

"Como contrapeso à autoridade, constitui-se a sociedade civil burguesa. As atividades e relações de dependência que, até então estavam confinadas ao âmbito da economia doméstica, passam o limiar do orçamento doméstico e surgem à luz da esfera pública" (HABERMAS 1984, p. 33).

Entrementes, com as mudanças das relações sociais, a vinculação público e privado se vê transformada pelo social

"A atividade econômica privatizada precisa orientar-se por um intercâmbio mercantil mais amplo, induzido e controlado publicamente; as condições econômicas, sob as quais elas ocorrem, agora estão fora dos limites da própria casa; são, pela primeira vez, de interesse geral" (HABERMAS 1984, p. 33).

e Habermas usa dos argumentos de Hannah Arendt ao tratar das esferas pública e privada, no capítulo "A promoção social" do livro "A condição humana". Ela considera a passagem da sociedade de uma administração caseira para a esfera pública como modificadora do significado destes dois termos e da relevância que tinham para os indivíduos. Isto se dá nas sociedades modernas em função do trabalho, única atividade necessária para manter a vida - o processo vital

"A sociedade é a forma na qual o fato da dependência mútua em prol da subsistência, e de nada mais, adquire importância pública, e na qual as atividades que dizem respeito à mera sobrevivência são admitidas em praça pública" (ARENDT 2000, p. 56).

A distinção entre o público e o privado da sociedade grega passou a manter uma relação diferenciada por volta do século XVI, quando o privado se contrapunha ao interesse comum e ao estatal numa concepção autoritária, para finalmente surgir então um 
novo conceito de publicidade, aqui como idéia de opinião, que dá força para a expressão pública de pessoas privadas ou melhor, permite a discussão crítica na esfera pública, que Habermas retoma mais tarde no desenvolvimento de seu programa teórico com o princípio crítico da publicidade retirada dos princípios kantianos. ${ }^{22}$

Enfim, no século XVIII, a estrutura básica de esfera pública burguesa surge entre o domínio de autoridade pública do Estado e o domínio de autoridade privada da sociedade burguesa. As esferas pública e privada são separadas à semelhança da divisão Estado e sociedade, sendo que o setor público limita-se ao poder público e o setor privado inclui a esfera pública porque este é um espaço composto de pessoas privadas. A esfera privada compreende a sociedade civil burguesa - setor de troca de mercadorias e do trabalho social; aí também se insere a família e sua esfera íntima. Intermediando as duas anteriores está a esfera pública política que proveio da literária ${ }^{23} \mathrm{e}$ que através da opinião pública intervém no Estado e nas necessidades da sociedade. A esfera pública burguesa é o fórum para onde se dirigiam as pessoas privadas a fim de obrigar o poder público a se legitimar frente a opinião pública, em uma situação pública não pertencente ao Estado.

Em seu livro "Direito e democracia: entre facticidade e validez", Habermas retoma a discussão e crítica do conceito de esfera pública, então de maneira integrada com toda a linguagem do seu programa teórico, definindo que

“(...) pode ser descrita como uma rede adequada para a comunicação de conteúdos, tomadas de posição e opiniões; nela os fluxos comunicacionais são filtrados e sintetizados a ponto de se condensarem em opiniões públicas enfeixadas em temas específicos. Do mesmo modo que o mundo da vida tomado globalmente, a esfera pública se reproduz através do agir comunicativo, implicando apenas o domínio de uma linguagem natural; ela está em sintonia com a compreensibilidade geral da prática comunicativa cotidiana. Descobrimos que o mundo da vida é um reservatório para interações simples; e os sistemas de ação e de saber especializados, que se formam no interior do mundo da vida, continuam vinculados a ele. Eles se ligam a funções gerais de reprodução de mundo da vida (como é o caso da religião, da escola e

\footnotetext{
${ }^{22}$ este assunto será tratado na seção Habermas e a ética do discurso.

${ }^{23}$ a esfera pública literária é a esfera pública de caráter não político e privado formado pelas pessoas que deram vida aos cafés, e círculos de leitores dos periódicos culturais.
} 
gerais de reprodução de mundo da vida (como é o caso da religião, da escola e da família), ou a diferentes aspectos de validade do saber comunicado através da linguagem comum (como é o caso da ciência da moral, da arte). Todavia, a esfera pública constitui principalmente uma estrutura comunicacional do agir orientado pelo entendimento, a qual tem a ver com o espaço social gerado no agir comunicativo, não com as funções nem com os conteúdos da comunicação cotidiana" (HABERMAS 1997, v. II, p. 92).

A próxima seção trata dos conteúdos expostos na "Teoria da comunicação". A argumentação desenvolvida em "Conhecimento e interesse" será tratada em conjunto, pois seus conteúdos foram revistos e complementados quando o autor elaborou sua teoria da comunicação - fundamentos da competência comunicativa desenvolvida nos anos $70 \mathrm{e}$ publicada em 1981.

\section{Habermas e o paradigma da comunicação}

Esta obra sistematiza todo o pensamento formulado por Habermas sobre a crítica da razão e a modernidade. Os conceitos básicos nela expostos fundamentam a compreensão de sua teoria moral e, é a partir dela que a teoria ética do discurso foi construída.

"Publicada en 1981, la Teoría de la Acción Comunicativa representa la culminación hasta la fecha de los esfuerzos de Habermas por reconstruir una teoría de la sociedad con intención prática" (McCARTHY 1995, p. 446).

O projeto filosófico de Habermas pautou-se desde o início pela crítica ao positivismo cientifico e filosófico e ao objetivismo tecnocrático. Esse assunto já fora tratado por ele em outras obras publicadas até então, e, em especial "Teoria e Prática: estudos da filosofia social" e "Conhecimento e Interesse". Em entrevista dada ao jornal Folha de São Paulo em 26/10/97 relata

“(...)Naquela época, atraía-me ainda o marxismo heideggeriano do primeiro Marcuse e o marxismo freudiano do Marcuse posterior. Eu tinha em vista algo como uma filosofia da história sociologicamente verificável. O que me interessava então em Kant, Hegel e Marx era sobretudo como eles haviam concebido o nexo entre teoria e prática. Só depois ocupei-me também da crítica da economia política, embora sem nunca atribuir à análise da formamercadoria o significado que ela sempre teve para Adorno. 
Nos anos 60, a tradição do marxismo ocidental era para mim principalmente uma chave para uma teoria da modernidade social estabelecida simultaneamente pela sociologia e pela crítica da razão. Mais tarde, porém, depois de 'Conhecimento e Interesse', isto é, no fim dos anos 60, abandonei os modelos de pensamento de uma filosofia materialista da história. A teleologia da história não é menos 'metafísica' que a da natureza" ( HABERMAS J. entrevista. Folha de São Paulo, São Paulo, 26 out 1997 Disponivel em $<\mathrm{URL}$ :http://www.uol.com.br/. Acesso em: [20 jun. 2001]).

O programa crítico exposto em "Conhecimento e Interesse" recebeu diversas críticas que, de certa maneira, levaram Habermas a afastar-se do marco de uma filosofia da consciência e do sujeito auto-consciente para a filosofia de linguagem desenvolvida na noção de ação comunicativa. ${ }^{24}$ Habermas pressupõe uma unidade indissociável de conhecimento e interesse, e demonstra que a neutralidade das ciências exigida por Marx Weber sucumbe ao exame crítico e portanto conclui que o conhecimento está sempre estabelecido por interesses. Assim, propõe três formas de interesses - técnico: que se enraíza nas estruturas da ação instrumental, baseada em regras técnicas, pelas quais o homem se relaciona com a natureza; prático: ou comunicativo, que se enraíza nas estruturas da ação comunicativa pela qual os homens se relacionam entre si por meio de normas linguisticamente articuladas e cujo objetivo é o entendimento mútuo; e, o terceiro, a quem os dois anteriores geram, emancipativo: que se enraíza em estruturas da ação reflexiva, criticamente orientada, pelas quais o homem se relaciona com o poder - a dominação. Como sintetiza SIEBENEICHLER

“(.) existem dois campos de objetos científicos que correspondem a dois interesses do conhecimento. De um lado, o campo das ciências experimentais que procuram decifrar a realidade empírica conduzidas por um interesse invariante na sua possivel utilização através do trabalho humano, ou seja, sob o ponto de vista do alargamento do agir técnico-instrumental. De outro lado, o campo das ciências histórico-hermenêuticas, que pesquisam o

\footnotetext{
${ }^{24} \mathrm{O}$ interesse sobre a temática do "Conhecimento e Interesse" foi tratado por Habermas dentro de suas reflexões sobre ideologia e a discussão com Edmund Husserl. Ambos compartilham a idéia de desfazer a dogmática objetivista e fundamentar o interesse em uma maioridade. Enquanto Husserl constrói uma teoria embasada na filosofia tradicional e na razão pura, Habermas compreende hegelianamente a teoria como um processo de formação e de aprendizagem.
} 
mundo cultural do presente e do passado levadas pelo interesse em ação comunicativa, procurando aproveitar as experiências armazenadas no mundo da tradição cultural, a fim de aproveitá-la para a vida social prática.

Entretanto, Habermas explora um terceiro interesse: o interesse em maioridade e emancipação, que ele liga às ciências críticas, à psicanálise e à teoria critica da sociedade, tidas como capazes de libertar a consciência da dependência em relação a poderes hipostasiados ideologicamente" (SIEBENEICHLER 1994, p. 81).

E é da argumentação do terceiro interesse, o emancipatório, que Habermas atinge o paradigma da linguagem. Buscando justificar este interesse ao tempo que quer descaracterizar qualquer conjetura ideológica, desenvolve uma metodologia apoiada na reflexão e auto-reflexão (cf. HABERMAS 1987, p. 23), apoiando-se em três conceitos originados de fontes diversas. Então, ele dialoga com a reflexão como forma de fundamentação racional transcendental kantiana, como dissolução crítica hegeliana e no sentido da psicanálise freudiana. Isto gera a discussão Gadamer-Habermas sobre hermenêutica e suas diversas objeções estão expostas no posfácio elaborado para o livro "Teoria e Prática" a partir da edição de 1973 (cf. HABERMAS 1987, p. 321-357). Ao reconhecer as críticas e, em especial de McCARTHY (cf. McCARTHY 1995, p 115-153), com respeito à insuficiência da argumentação na justificativa do interesse emancipatório com bases em uma teoria do conhecimento, Habermas apoia-se na linguagem e na lógica da comunicação como quadro de referência para argumentar em defesa da emancipação, levando-o a elaborar a teoria da ação comunicativa.

Habermas dividiu o livro em dois tomos: o primeiro versa sobre a racionalidade da ação e racionalização social e, o segundo, sobre a crítica da razão funcionalista. $\mathrm{Na}$ introdução o autor descreve a metodologia aplicada

“(...) El libro que ahora presento lo he escrito duante los último cuatro años, (...) La categoría de acción comunicativa la desarollo en el Interlúdio Primeiro. Permite acceder a tres complejos temáticos que se ensamblam entre sí: se trata en primer lugar de un concepto de racionalidad comunicativa, que he desarrollado con el suficiente escepticismo, pero que es capaz de hacer frente a las reducciones cognitivo-instrumentales que se hacen de la razón; en segundo lugar, de un concepto de sociedad articulado en dos niveles, que 
asocia los paradigma de mundo de la vida y sistema, y no sólo de forma retórica. Y finalmente, de uma teoría de la modernidad que explica el tipo de patologías sociales que hoy se tornam cada vez más visibiles, mediante la hipótesis de que los ámbitos de acción comunicativamente estructurados quedan sometidos a los imperativos de sistemas de acción organizados formalmente que se han vuelto autónomos. Es decir, que la teoría de acción comunicativa nos permite una categorización del plexo de la vida social, con la que se puede dar razón de las paradojas de la modernidade" (HABERMAS 1988; p. 10).

Mais uma vez saliento que não é objeto deste estudo uma análise detalhada desta obra e sim retirar os conceitos que levem a uma melhor compreensão da ética discursiva. Portanto abordarei seus aspectos basilares para o entendimento da próxima seção.

Em princípio, todos os afetados - em condição de igualdade e liberdade - podem participar em busca cooperativa da verdade, onde a coerção somente será exercida pelo melhor argumento dado. Esta pressuposição pragmática vincula-se às estruturas do mundo da vida e tem caráter universal. Assim,

"La pragmática universal tiene como tarea identificar y reconstruir las condiciones universales del entendimiento posible. En otros contextos se habla también de 'pressupuestos universales de la comunicación'; pero prefiero hablar de presupuestos universales de la acción comunicativa porque considero fundamental el tipo de acción orientada para el entendimiento" (HABERMAS 1994, p. 299).

Entendimento ou comunicação voltada ao consenso é um processo social que se dá através da linguagem entre os participantes de uma determinada praxis social. A linguagem representa um traço distintivo da humanidade e Habermas sustenta que os atos ilocucionais ou atos de fala de agentes comunicativamente competentes se conformam a um conjunto de regras. Pelo tal, utiliza a idéia de princípio reconstrutivo: a explicitação e reconstrução sistemática da aplicação de tais regras, aplicadas por sujeitos sem a consciência de sua existência nos atos de fala e de ação.

Este princípio foi elaborado com base na teoria dos jogos de linguagem criada por Wittgeinstein que consiste na tentativa de conceber o jogo como modelo de linguagem e, em especial, o que denomina o status das regras do jogo e a competência dos jogadores 
que as dominam e delas se utilizam para fazer a conexão entre a observação de uma regra e as críticas a sua violação. Wittgeinstein insiste na relação interna que existe entre a competência de seguir uma regra e a capacidade de tomar uma postura do tipo sim ou não frente à questão se um símbolo está sendo utilizado corretamente, ou seja, em conformidade com a regra que exige seu empenho (cf. HABERMAS 1988, vol. II p. 29-37; HABERMAS 1984, p. 63-76) e agregado ao aspecto de performance da teoria de gramática generativa de Noam Chomsky, ${ }^{25}$

“ La propuesta de investigar el empleo del lenguaje en términos de teoría de la competencia comunicativa exige una revisión de los conceptos de competencia y realización. Chomsky entiende de entrada estos conceptos de la siguiente forma: tiene sentido envestigar las propriedades fonéticas, sintácticas y semánticas de las oraciones en el marco de una reconstrucción de la competencia (competence) lingüística y dejar las propriedades pragmáticas de las emisiones a una teoría de la realización (performance) lingüística" (HABERMAS 1994, p. 326)

e a teoria dos atos de fala de John L. Austin e John R. Searle.

Atos de fala são unidades elementares do processo da comunicação lingüística. Austin analisou o sentido em que se pode emitir uma oração em atos de fala ou ações de fala com força elucucionária ${ }^{26}$ e separou estes atos em locucionários, ilocucionários e perlocucionários

“(...)Con los actos locucionarios el hablante expressa estado de coisas; dice algo. Con los actos ilocucionarios el agente realiza una acción diciendo algo. (...) Con los actos perlocucionários el hablante busca causar un efecto sobre su oyente. Mediante la ejecución de un acto de habla causa algo en el mundo. Los tres actos que distingue Austin pueden, por tanto, caracterizar-se

\footnotetext{
${ }^{25}$ Performance equivale ao número finito de sentenças gramaticais realizadas por um falante gerado em evidências para uma investigação de competência, aqui entendida, não implicando em uma apreciação e invocação de regras generativas por parte do falante, e sim na competência como a verdadeira condição para a possibilidade de linguagem.

${ }_{26}$ Austin demonstrou que os locutores, ao dizerem alguma coisa também fazem alguma coisa e este fazer alguma coisa é o que Austin chamou de força elocucionária de uma forma de expressão (cf. White 1995, p. 37).
} 
de la siguiente forma: decir algo; hacer diciendo algo; causar algo mediante lo que se hace diciendo algo" (HABERMAS 1988, vol. I, p. 370-371).

$O$ ato de fala encontra-se constituido de um elemento locucionário em que a proposição apresenta uma força ilocucionária que define o seu uso. Searle, mais tarde, vai propor para estes atos de fala uma série de regras próprias que definem o uso correto de frases contendo verbos de ação restrita ao âmbito da linguagem. Como introduz Habermas

"Searle há tratado de dar forma más precisa a esta clasificación de Austin. No se guia por una lista de verbos realizativos que hayan podido formarse en una determinada lengua, sino por las intenciones o metas ilocucionarias que un hablante persigue con los distintos tipos de actos de habla, con independencia de las formas en que éstos se realicen en cada lengua particular" (HABERMAS 1988, vol. I, p. 409)

e expõe as cinco classes de denominação: constatativos, compromissórios, diretivos, declarativos e expressivos.

Conforme Habermas, esta versão apurada por Searle dos tipos austinianos ${ }^{27}$ de atos de fala caracteriza a situação de partida para uma discussão em duas direções- uma que deu fundamentação ontológica a estes cinco tipos de atos de fala seguida por outra que vem definida pela tentativa de reconstruir o ponto de vista da pragmática empírica, de modo que possa servir para a análise das seqüências dos atos de fala da comunicação cotidiana (cf. HABERMAS 1988, vol. I, p. 410).

Lembre-se aqui que Habermas propôs o nome de pragmática universal para o programa de investigação que tem por objeto reconstruir a base universal de validez da fala (cf. HABERMAS 1994, p. 302). Para ele a verdade é a pretensão de validade que ligamos a atos de fala constatativos, ou seja, justificados através de argumentos. O objetivo da análise reconstrutiva da linguagem é a descrição explícita das regras que um falante competente deve dominar para formar e emitir orações gramaticalmente corretas e, essa postula uma correspondente competência de regra comunicativa: a competência de usar orações em atos de fala.

Quando um locutor entra então em ação comunicativa ele tem que ser responsável por quatro reivindicações: inteligibilidade, verdade, veracidade e retidão.

\footnotetext{
${ }^{27}$ Em uma primeira tentativa de tipologia dos atos de fala, Austin ordenava os atos ilocucionários valendo-se de verbos realizativos e é desta classificação que Searle elaborou a sua forma.
} 
"Cuento, pues, como acción comunicativa aquellas interaciones mediadas lingüisticamente en que todos los participantes persiguen con sus actos de habla fines ilocucionarios y solo fines ilocucionarios. Las interaciones, en cambio, en que a lo menos uno de los participantes pretende com sus actos de habla provocar efectos perlocucionarios en su interlocutor las considero como acción estratégicamente mediada lingüisticamente" (HABERMAS 1988, vol. I, p. 378).

Questões de verdade somente aparecem quando as pretensões de validade passam a ser problematizadas através da lógica do discurso argumentativo, isto é

“(...) com uma fundamentação que deve nos motivar racionalmente a reconhecer as pretensões de validade de uma afirmação, de um mandamento ou de uma avaliação. Os argumentos passam a ser avaliados ou pesados quanto à sua força consensual, isto é, com relação à sua capacidade de obter o consenso fundamental racionalmente" (SIEBENEICHLER 1994, p. 101).

Com o paradigma da comunicação e, sendo os conceitos usuais de mundo da vida para a sociologia compreensiva somente úteis para a exposição de narrativas de acontecimentos históricos e situações sociais, Habermas necessita reconstruir um espaço societário onde possa ocorrer a interação entre os individuos mediada simbolicamente pela linguagem e que seja organizada sobre uma base de normas que delimitem expectativas reciprocas. A partir daí ele define a sociedade moderna dividida em dois mundos: o sistêmico e o mundo da vida. Um é dado por uma perspectiva externa - subjetivo do indivíduo em que domina a ação instrumental; o outro representa uma perspectiva interna intersubjetivo em que domina a ação comunicativa.

O conceito de mundo da vida envolve o contexto dos processos de comunicação voltado ao entendimento e ao consenso obtido através dos atos de fala

“El mundo de la vida es, por así decirlo, el lugar transcendental en que o hablante y oyente se salen al encuentro; en que pueden plantearse reciprocamente la pretensión de que sus emisiones concuerdan con el mundo (con el mundo objetivo, con el mundo subjetivo y con el mundo social); y en que pueden criticar y exhibir los fundamentos de esas pretensiones de validez, resolver sus disentimentos y llegar a un acuerdo. En una palabra: respecto al lenguaje y a la cultura los participantes non pueden adoptar in actu la misma 
distancia que respecto a la totalidad de los hechos, de las normas o de las vivencias, sobre que es posible el entendimiento" (HABERMAS 1988, vol. II, p. 179).

Descrito o cenário de atuação da ética do discurso ainda resta expor um último conceito - a situação ideal de fala

"Llamo ideal a una situacón de habla en que las comunicaciones non solamente no vienem impedidas por influjos externos contingentes, sino tampoco por las coacciones que se siguem de la própria estrutura de la comunicación. La situación ideal de habla excluye las distorsiones sistemáticas de la comunicación. Y la estructura de la comunicación deja de generar coacciones sólo si para todos los participantes en el discurso está dada una distribuición simétrica de las oportunidades de elegir y ejecutar actos de habla" (HABERMAS 1994, p. 153).

Este conceito foi dado para inserir a linguagem na realidade social e não pode ser visto como um fenômeno empírico ou ser uma simples construção. As leituras feitas neste sentido provocaram diversas objeções apesar de Habermas alertar que este princípio não é simplesmente um princípio regulativo no sentido kantiano. A partir do primeiro ato para o entendimento lingüístico, facticamente teríamos de ter feito de antemão esta suposição que serve para questionar qualquer consenso obtido. Enfim, um critério de argumentação discursiva que implica uma distribuição simétrica de chances de escolha e de realização de atos de fala (cf. HABERMAS 1994, p. 111).

O sentido da universalização é condição para a discussão da ética do discurso particularmente para o envolvimento na argumentação do tipo pós-convencional. Não cabe aqui fazer uma discussão teórico-filosófica sobre este polemico assunto e sim anuir a situação ideal de fala como uma medida crítica e não como uma forma de vida concreta, ou seja, aceitar como um critério de argumentação que será utilizado no modelo de minha análise $^{28} \mathrm{e}$ em especial concordo com SIEBENEICHLER quando diz

"Significa apenas que a idéia de uma forma de vida ideal, mesmo que seja pensada de diferentes maneiras, por seres humanos diferentes, em épocas

\footnotetext{
${ }^{28}$ As discussões feitas por Habermas sobre estas objeções podem ser vistas em seu livro "Teoria de acción comunicativa: complementos y estudios previos" no capítulo "Réplica a objeciones (1980)" (HABERMAS 1994, p.399-478).
} 
distintas, tem de ocupar-se constantemente com as idéias: verdade, liberdade, justiça e reciprocidade" (SIEBENEICHLER 1994, p. 107).

\section{Habermas e a Ética Do Discurso}

A teoria da ética do discurso ou, como diria Habermas mais tarde, teoria discursiva da moral, desenvolver-se-á tendo como núcleo referencial três livros que apresento em ordem cronológica de publicação: "Consciência moral e agir comunicativo" (HABERMAS 1989), "Escritos sobre eticidade e moralidade”, (HABERMAS 1991) e " Aclaraciones a la ética del discurso" (HABERMAS 2000a). ${ }^{29}$

A ética do discurso compartilha dos supostos deontológicos, cognitivistas, formalistas e universalistas básicos da ética kantiana. Habermas ao explicar o significado da ética do discurso, o faz partindo destes quatro pressupostos cotejando-os com a construção de seu pensamento (cf. HABERMAS 1991, p. 69).

Quadro 1 - Comparação dos pressupostos da ética kantiana e ética do discurso

\begin{tabular}{|c|c|c|}
\hline Pressupostos & Ética Kantiana & Ética do Discurso \\
\hline deontológico & $\begin{array}{l}\text { - conceito estrito de moral - o } \\
\text { dever ser: ação correta e justa } \\
\text { - validez deôntica de mandatos } \\
\text { e normas }\end{array}$ & $\begin{array}{l}\text { - o dever ser } \\
\text { - validez como pretensão de } \\
\text { validez análoga a verdade }\end{array}$ \\
\hline cognitivista & $\begin{array}{l}\text { - responde com base de um } \\
\text { acordo racionalmente motivado a } \\
\text { questão de como fundamentar } \\
\text { enunciados normativos }\end{array}$ & $\begin{array}{l}\text { - o princípio de universalização } \\
\text { pode ser universalmente justificado } \\
\text { através da razão }\end{array}$ \\
\hline formalista & $\begin{array}{l}\text { - imperativo categórico como } \\
\text { princípio de justificação moral }\end{array}$ & $\begin{array}{l}\text { - procedimento da argumentação } \\
\text { moral como forma de justificação } \\
\text { moral }\end{array}$ \\
\hline unive & - prir & - $\mathrm{pr}$ \\
\hline
\end{tabular}

${ }^{29}$ Estes três livros correspondem às publicações originais em alemão: "Consciência moral $e$ agir comunicativo" (HABERMAS 1989), Moralbewusstein und Kommunikatives Handlein", 1983; "Escritos sobre eticidade e moralidade", (HABERMAS 1991), que reúne três publicações: "Moralitätat und Sittlichkeit. Treffen Hegels Einwände gegen Kant auch auf die Diskursethik zu? In: Moralitätat und Sittlichkeit, 1986; "'Uber Moralität und Sittlichkeit - Was macht eine Lebensform rational? In: Rationalität, 1984 e "Wie ist Legitimität durch Legalität möglich?", 1987 e "Aclaraciones a la ética del discurso", (HABERMAS 2000), "Erläuterungen zur Diskursethik", 1991. 
Desse modo, Habermas não trabalha com validez normativa e sim com pretensões de validez que aduz como análoga à verdade, transcrevendo a idéia de imperativo categórico "Age apenas segundo uma máxima tal que possas com o tempo querer que ela se torne em lei universal", ${ }^{30}$ que é um princípio de justificação que seleciona e distingue como válidas as normas de ação suscetiveis de universalização, em um procedimento de argumentação para determinar o princípio " $D$ "

"uma norma só deve pretender validez quando todos os que possam ser concernidos por ela cheguem (ou possam chegar), enquanto participantes de um discurso prático" (HABERMAS 1989, p. 86, grifo da autora).

$\mathrm{O}$ imperativo categórico para Kant constitui um teste que cada indivíduo pode realizar monologicamente, isto é, cada um pergunta a si mesmo se ele pode querer que uma norma proposta seja uma lei universal. Habermas inclui nesse espaço de discussão um processo coletivo de escolha de interesses e necessidades que possa levar a eleger racionalmente uma norma para guiar uma dada ação e que a mesma não ocorra antes de um discurso real entre os envolvidos. Então, constitui um outro teste que aceita ou refuta se uma norma proposta é aceitável numa argumentação real a todos os potencialmente afetados por esta e se esta satisfaz os interesses da cada participante no argumento.

Dois termos importantes devem ser conceituados para o entendimento do princípio.

O significado de pretensão de validez que é concebido a partir do entendimento da verdade proposicional como uma pretensão elevada com atos de fala constatativos e, portanto, realizado exclusivamente através de pressupostos comunicativos de argumentação, ou seja, suas condições de validez resultam de razões apresentadas no discurso. Para tanto o falante ergue as seguintes pretensões: a) que o enunciado formulado é verdadeiro (pretensões de verdade); b) que o ato da fala é correto relativamente a um contexto normativo existente (pretensões de correção); e c) que a interação manifesta do falante é visada do modo como é proferida, (pretensões de sinceridade); conforme os falantes se refiram a algo do mundo objetivo, ao mundo social comum e ao mundo subjetivo próprio (cf. HABERMAS 1988, p. 391-407). Então a verdade e a correção é observada na apresentação de razões e sinceridade na consistência de seu comportamento.

\footnotetext{
${ }^{30}$ a noção de imperativo categórico foi formulado por Kant em seu livro "Fundamentação da metafísica dos costumes" (KANT 1997). Sua leitura é bastante interessante, pois Kant descreve várias formulações no decorrer do livro e muito se discute com respeito a esta pluralidade - seu motivo e articulação - nos meios filosóficos e como os diversos pensadores os articularam nas suas construções teóricas.
} 
Habermas define discurso como uma modalidade de comunicação para reivindicação de verdade (discurso teórico) e de legitimidade (discurso prático). Assim, discurso prático é um processo de exame de validade das normas consideradas hipoteticamente. Ele corresponde ao conceito de "ponto de vista moral" ${ }^{\text {"1 }}$ e coloca os participantes de uma argumentação como iguais e livres na busca cooperativa de uma verdade onde não é permitido coerção a não ser a resultante de melhores argumentos. Pode ser compreendido como um processo de entendimento mútuo que por sua forma argumentativa coloca todos os participantes na situação de imparcialidade privilegiando ao discurso prático a imparcialidade do juízo moral.

Aqui o participante não é mais visto pelo eu observador da forma transcendental do modelo kantiano. Este olhar objetivo e monológico é substituído por uma perspectiva da primeira pessoa do plural onde cada um pode olhar os interesses de todas as pessoas participantes em um discurso público.

A sustentação teórica da ética do discurso é dada pela proposição de que reivindicações de validade normativa têm um sentido cognitivo e para tal Habermas usa pistas da tradição da psicologia desenvolvimental cognitiva de Piaget-Kohlberg.

Habermas parte da tese de Kohlberg $^{32}$ de que os juízos morais se apresentam em todas as sociedades com a mesma estrutura. É importante compreender que esta idéia não reside em estabelecer-se o sentido universal como uma generalização de normas justificadas e sim na forma de verificação de validez das normas existentes e que se tornaram problemáticas. O modelo elaborado por Habermas foge de outras construções de éticas de tipo kantiano que defendem o universalismo partindo de abstrações. À exemplo, John Rawls, quando recomenda uma posição original partindo do pressuposto kantiano de que o consenso original é hipotético.

' $\mathrm{Na}$ justiça como eqüidade a posição original de igualdade corresponde ao estado de natureza na teoria tradicional do contrato social. Essa posição original não é, obviamente, concebida com uma situação histórica real, muito menos como uma condição primitiva da cultura. É entendida como uma situação hipotética caracterizada de modo a conduzir a uma certa concepção de

\footnotetext{
${ }^{31}$ A denominação "ponto de vista moral" vem da tradição kantiana e indica uma condição de imparcialidade para avaliação de questões morais.

${ }^{32}$ Kohlberg foi amigo pessoal de Habermas e um importante pensador no campo da psicologia e educação moral.
} 
justiça. Entre as caracteristicas essenciais dessa situação está o fato de que ninguém conhece o seu lugar na sociedade, a posição de sua classe ou o status social e ninguém conhece a sua sorte na distribuição de dotes e habilidades naturais, sua inteligência, força, e coisas semelhantes. Eu até presumirei que as partes não conhecem suas concepções do bem ou suas propensões psicológicas particulares. Os princípios da justiça são escolhidos sobre o véu de ignorância" (RAWLS 1997, p. 13).

Ao contrário, devemos partir do entendimento de que conflitos de ação que se pretendem avaliar moralmente e dar soluções consensuais emergem da prática comunicativa cotidiana

“(...) são encontradas, e não produzidas, pela razão que examina máximas ou pelos participantes da argumentação" (HABERMAS 2000a, p. 21).

Mas a competência do falante não é concedida e pelo tal esta deve combinar seus papéis comunicacionais com suas perspectivas de falante para inteirar-se e compreender o cotidiano. Habermas descreve o seu participante não como um eu-transcendental kantiano mas o coloca numa perspectiva de uma terceira pessoa que opera

"como um sujeito solitário, que reúne e avalia seus dados em cada caso à luz de seu próprio modo de ver o mundo e de ver-se a si mesmo, enquanto que, ao contrário, a imparcialidade do juízo depende essencialmente de que as necessidades e interesses rivais de todos os participantes podem fazer-se valer e podem ser levados em conta a partir do ponto de vista dos implicados mesmos" (HABERMAS 2000a, p. 160)

e permite um comportamento reflexivo dos participantes em suas argumentações em um discurso público.

Kohlberg também se utilizou da tradição kantiana para discorrer sobre a natureza do juizo moral tomando três premissas - cognitivismo, universalismo, formalismo - para discutir o desenvolvimento moral e elaborar o que denominou estádios morais.

"Kolhberg explica o ponto de vista moral do julgamento imparcial dos conflitos morais de ação, recorrendo ao conceito de assunção ideal de rol, que Mead havia utilizado já como correlato de um discurso universal para 
reformular a idéia básica da ética kantiana no marco de sua teoria de ação" (HABERMAS 2000a, p. 64).

Assim sendo, determinou seis estágios de juizo moral e que se podem compreender nas dimensões da reversibilidade dos pontos de vista que os participantes apresentam seus argumentos, da universalidade no sentido de inclusão de todos os envolvidos e da reciprocidade do reconhecimento igual das pretensões de cada participante por todos os demais, como uma aproximação gradual das estruturas da avaliação imparcial de ação moralmente relevantes.

"Ego tiene que empezar cumpliendo la condición de una empatia simpática en la situación del otro, tiene sencillamente que identificarse con él para poder asumir exactamente la misma perspectiva desde la que alter podria hacer valer sus expectativas, intereses, orientación axiológica, etc., en caso de conflito moral. A continuación ego tiene que poder suponer que la asunción de una perspectiva ajena no se realiza unilateral, sino recíprocamente. Se espera de alter que asuma la perspectiva de ego de la misma manera, a fin de que el modo de actuar en cuestión pueda ser percibido y tematizado de modo concordante teniendo en cuenta los intereses afectados en los dos lados. En situaciones más complejas, esta relación didática tiene que ser ampliada hasta la imbricación de perspectivas entre los miembros de un grupo particular. Solo con este presupuesto sociocognitivo puede otorgar cada uno a los intereses de los demás el mismo peso que a los propios cuando se trate de juzgar si una praxis universal podría ser aceptada por buenas razones por otros compañeros igual que lo es por él mismo. Finalmente, ego tiene que cumplir la condición de la universalizabilidad de su reflexión, que en primer momento es interna al grupo y está referida a interacciones sencillas: tiene que prescindir de las circunstancias concretas de una determinada interacción y examinar abstractamente si en circunstancias comparables una praxis universal podria ser aceptada sin coacción, por cada uno de los potencialmente afectados, desde el punto de vista de su propia constelación de intereses. Esto exige una intercambiabilidad universal de las perspectivas de todos los afectados; ego tiene que poder imaginarse cómo se pone cada uno en la situación de cada uno de los demás" (HABERMAS 2000a, p. 64-65). 
Desse modo, o desenvolvimento de seus estádios morais foram distribuídos em três níveis que o autor considera como passagens de aprendizado.

\section{Nível A - Nível Pré-convencional}

Estádio 1 - O estádio do castigo e da obediência:

$\mathrm{O}$ direito é a obediência literal às regras (obedecer por obedecer) e à autoridade, evitar o castigo e não fazer o mal físico.

Estádio 2 - O estádio do objetivo instrumental individual e da troca:

$\mathrm{O}$ direito é seguir as regras quando for de seu interesse imediato, satisfazer os interesses e necessidades próprias e deixar que os outros façam o mesmo e reconhecer que as outras pessoas também tem seus interesses;

\section{Nível B - Nivel Convencional}

Estádio 3 - O estádio das expectativas interpessoais mútuas, dos relacionamentos e da conformidade:

O direito é desempenhar o papel de uma pessoa boa (amável), é preocupar-se com as outras pessoas e seus sentimentos, manter-se leal e conservar a confiança dos parceiros e estar motivado a seguir regras e expectativas. Neste estádio, temos a necessidade de ser bons e importar-nos com os outros de forma que se nos colocássemos no lugar dos outros iríamos querer um bom comportamento de si próprio (Regra de Ouro);

Estádio 4 - $O$ estádio da preservação do sistema social e da consciência:

O direito é fazer o seu dever na sociedade, apoiar a ordem social e manter o bem-estar da sociedade ou do grupo com a finalidade de manter em funcionamento a instituição como um todo, o auto-respeito ou a consciência compreendida como o cumprimento das obrigações definidas para si próprio ou a consideração das consequiências: "E se todos fizessem o mesmo?";

\section{Nivel C - Nivel pós-convencional ou baseado em principios}

As decisões morais são geradas a partir de direitos, valores ou princípios com que concordam (ou podem concordar) todos os individuos compondo ou criando uma sociedade destinada a ter práticas leais ou benéficas.

Estádio 5 - O estádio dos direitos originários e do contrato social ou da utilidade:

O direito é sustentar os direitos, valores e contratos legais básicos de uma sociedade, mesmo quando entram em conflito com as regras e leis concretas do grupo. A obediência se dá pela existência de um contrato social que protege os próprios direito e os direitos dos outros. O que importa que as leis e deveres sejam baseados num cálculo racional de utilidade geral: "o maior bem para o maior número";

Estádio 6 - O estádio de princípios éticos universais: 
Esse estádio presume a orientação por princípios éticos universais, que toda humanidade deve seguir e que enquanto pessoas racionais percebemos a validade destes princípios e nos comprometemos com eles (cf. HABERMAS 1989, p. 150-154). ${ }^{33}$

Para explicar o modo de agir do participante dentro dos diversos estádios de desenvolvimento Habermas então agrega as perspectivas de ação de R. Selman baseadas nas concepções de pessoas e relações para construir o desenvolvimento cognitivo do falante integrante da ética do discurso. ${ }^{34}$ Estas perspectivas distribuem-se em três níveis:

Nível 1 - Adoção de perspectiva diferenciada e subjetiva (cerca de 5 a 9 anos de idade)

Conceitos de pessoas: Diferenciados. No nível 1 , o avanço conceptual decisivo é a clara diferenciação das características físicas e psicológicas das pessoas. Resulta daí a diferenciação de atos intencionais e atos não-intencionais e a formação de uma nova consciência de que cada pessoa tem uma vida psicológica única, subjetiva e oculta. Contudo, os estados de pensamento, opinião ou sentimento no interior de um indivíduo são vistos como unitários, não como misturados.

Conceitos de relações: Subjetivos. As perspectivas subjetivas próprias e do outro são claramente diferenciadas e reconhecidas como potencialmente diferentes. Contudo, ainda se pensa que a simples observação física basta para ler o estado subjetivo de outrem. O relacionamento das perspectivas é concebido em termos unilaterais, de mão única, em termos da perspectiva de um ator ${ }^{35}$ e do impacto sobre o mesmo. Por exemplo, nessa concepção simples e unidirecional do relacionamento das perspectivas e da causalidade interpessoal, um presente torna alguém feliz. Onde há uma compreensão qualquer da reciprocidade de mão dupla, ela está ligada ao físico - a criança em que se bate, bate de volta. Os indivíduos são vistos como respondendo à ação com ação similar.

Nível 2 - Adoção de perspectiva auto-reflexiva / na segunda pessoa e recíproca (cerca de 7 a 12 anos de idade)

\footnotetext{
${ }^{33} \mathrm{O}$ ponto fundamental do estágio 6 é que ele é guiado por princípios éticos universais. As leis ou acordos sociais particulares são, em geral, válidos porque se apoiam em tais princípios. Quando as leis violam esses princípios, nós agimos de acordo com eles. Estes são os princípios universais de justiça; a igualdade de direitos humanos enquanto indivíduos; não são meramente valores reconhecidos, mas também são princípios usados para gerar decisões particulares.

34 "Kohlberg também estabeleceu uma relação de perspectivas sócio-morais para a formulação de seus estádios mas Habermas, assim como Carol Gilligan, encontra problemas para sua utilização pois não se percebe uma integração de equidade e autonomia" (WHITE S.K. 1995, p 85-87) Habermas retoma as perspectivas de Kohlberg e as relaciona com seus estádios de interação ao final de sua formulação.

${ }^{35}$ o sentido dado para a palavra ator é o de agente racional de ação, aqui usado no sentido sociológico dado por Habermas.
} 
Conceitos de pessoas: Auto-reflexivos / na segunda pessoa. Os avanços conceituais decisivos no nível 2 são a crescente habilidade da criança para sair mentalmente fora de si mesma e adotar uma perspectiva autoreflexiva ou na segunda pessoa - sobre os seus próprios pensamentos e ações bem como sobre a percepção de que os outros podem fazer o mesmo. Os estados de pensamento ou do sentimento das pessoas são vistos como potencialmente múltiplos (por exemplo, curiosos, assustados e felizes), mas ainda como agrupamentos de aspectos mutuamente isolados e seqüenciais ou ponderados (por exemplo, sobretudo curiosos e felizes e um pouco amedrontados). Deste modo, os próprios e os outros são interpretados como incapazes de fazer coisas (ações manifestas) que podem não querer (ter a intenção de) fazer. $\mathrm{E}$ as pessoas são interpretadas como tendo uma orientação dual, clivada: a aparência visível, possivelmente encenada para exibir-se e a realidade oculta mais verdadeira.

Conceitos de relação: Recíprocos. As diferenças das perspectivas entre si são vistas numa óptica relativística por causa do reconhecimento, por parte da criança no nível 2 , da singularidade do conjunto ordenado de valores $\mathrm{e}$ objetivos de cada pessoa. Uma nova reciprocidade nos dois sentidos é o símbolo distintivo dos conceitos de relações de nível 2. É uma reciprocidade de pensamentos e sentimentos e não meramente de ações. A criança coloca-se na pele de outrem e percebe que o outro fará o mesmo. Em termos estritamente lógico-mecânicos, a criança vê agora a possibilidade do regresso infinito na adoção de perspectiva (eu sei que ela sabe que eu sei que ela sabe...etc.). A criança também reconhece que a distinção aparência externa-realidade interna significa que os próprios podem iludir os outros quanto a seus estados internos, o que põe limites de exatidão para a adoção da perspectiva interna de outrem. Essencialmente, a reciprocidade nos dois sentidos desse nivel tem o resultado prático da distensão, com o que ambas as partes ficam satisfeitas, mas em relativo isolamento; dois indivíduos particulares vendo a si mesmo e o outro, mas não o sistema de relações entre eles.

Nível 3 - Adoção da perspectiva da terceira pessoa e mútua (cerca de 10 a 15 anos de idade)

Conceito de pessoas: terceira pessoa. O jovem adolescente pensando no nível 3 vê as pessoas como sistemas de atitudes e valores razoavelmente consistentes a longo prazo, por oposição a grupos de estados aleatoriamente variáveis como no nível 2 . O avanço conceitual crítico faz-se em direção à habilidade de assumir uma verdadeira perspectiva da terceira pessoa, de sair não apenas de sua própria perspectiva imediata, mas fora do sipróprio como um sistema, uma totalidade. Aí são geradas noções do que poderíamos chamar de "ego observador", de tal modo que os adolescentes 
efetivamente se vêem a si próprios (e percebem as outras pessoas como vendo a si próprias) ao mesmo tempo como atores e como objetos, simultaneamente, agindo e refletindo sobre os efeitos da ação sobre si próprios, refletindo os sipróprios em interação com o si-próprio.

Conceitos de relações: mútuos. A perspectiva da terceira pessoa permite mais do que assumir a perspectiva de outrem sobre o si-próprio; a verdadeira perspectiva da terceira pessoa sobre as relações que é característica do nível 3 inclui e coordena simultaneamente as perspectivas do si-próprio do(s) outro(s) e assim, o sistema ou situação e todas as partes são vistos da perspectiva da terceira pessoa ou do outro generalizado. Enquanto que, no nível 2, a lógica do regresso infinito, encadeado para a frente e para trás, era de fato aparente, suas implicações não eram. No nível 3, as limitações e futilidade última das tentativas de compreender as interações com base no modelo do regresso infinito tornam-se aparentes e a perspectiva a terceira pessoa desse nivel permite ao adolescente sair fora abstratamente de uma interação interpessoal, bem como simultânea e mutuamente coordenar e considerar as perspectivas (e suas interações) do si-próprio e do(s) outro(s). Os sujeitos pensando nesse nível vêem a necessidade de coordenar perspectivas recíprocas e acreditam que a satisfação social, a compreensão ou a resolução devem ser mútuas e coordenadas para serem genuinas e eficazes. As relações são vistas mais como sistemas em funcionamento nos quais os pensamentos e as experiências são mutuamente compartidos (cf. HABERMAS 1989, p. 173178).

A coordenação de planos de ação exige reciprocidade das perspectivas do falante em entrelaçamento com as perspectivas de ação. Tomando como base estas investigações quanto à adoção de perspectivas dadas por Selman, Habermas relacionou-as com as formulações de Kohlberg construindo um modelo de estádios de interação - sujeito e suas reflexões morais - e que se refere aos discursos. $O$ resultado, conforme o quadro a seguir demonstra, indica que as perspectivas sociais podem ser correlacionadas com diferentes estádios de interação e as diferentes formas de consciência moral (Quadro 2).

O quadro distribui os três estádios de interação: pré-convencional, convencional e pós-convencional construídos segundo a lógica do desenvolvimento onde o estádio estabelece a idéia de hierarquização dos tipos de ação. No primeiro estádio as perspectivas de ação de diferentes participantes são relacionadas uma à outra reciprocamente; no estádio convencional, vincula-se a esta perspectiva uma perspectiva de observador e no terceiro apresentam-se integradas as perspectivas do falante e do mundo. 
QUADRO 2 - ESTÁDIOS DE INTERAÇÃO, PERSPECTIVAS SOCIAIS E ESTÁDIOS MORAIS

\begin{tabular}{|c|c|c|c|c|c|c|c|}
\hline \multirow{2}{*}{\begin{tabular}{|l|}
$\begin{array}{l}\text { Estruturas } \\
\text { cospitive }\end{array}$ \\
Tipos de aqäo \\
\end{tabular}} & \multirow{2}{*}{$\begin{array}{l}\text { Estruburas de } \\
\text { perspectives }\end{array}$} & \multirow{2}{*}{$\begin{array}{l}\text { Estrutura de expectativa } \\
\text { de compartam ento }\end{array}$} & \multirow{2}{*}{ Concerito de attoridesto } & \multirow{2}{*}{$\begin{array}{l}\text { Conctito do } \\
\text { motiraçäo }\end{array}$} & \multicolumn{2}{|c|}{ Permpectivas sociais } & \multirow{2}{*}{$\begin{array}{c}\text { Extidio } \\
\text { do } \\
\text { jứ } \\
\text { max } \\
\end{array}$} \\
\hline & & & & & Perepectiva & Representagăo do justiga & \\
\hline Pr6-convencionel: & \multirow{3}{*}{$\begin{array}{l}\text { Conex zoo reciproce de } \\
\text { perspectives do afjo }\end{array}$} & \multirow{3}{*}{$\begin{array}{l}\text { Padräo de } \\
\text { comportam ento } \\
\text { particasl ar }\end{array}$} & \multirow{3}{*}{ 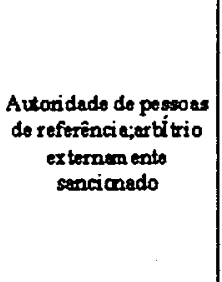 } & \multirow{3}{*}{ 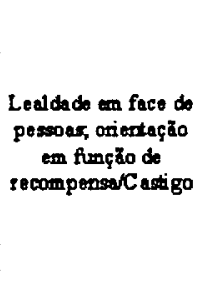 } & \multirow{3}{*}{$\begin{array}{l}\text { Perspectiva } \\
\text { egocếntica }\end{array}$} & \multirow[b]{2}{*}{$\begin{array}{c}\text { Camplem ertariodade de } \\
\text { ardem o obediôncia }\end{array}$} & \multirow[b]{2}{*}{1} \\
\hline 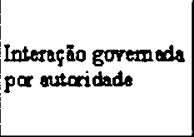 & & & & & & & \\
\hline $\begin{array}{l}\text { Coopereçä } \\
\text { goveoneds pox } \\
\text { inter esse }\end{array}$ & & & & & & $\begin{array}{l}\text { Sim etria dos } \\
\text { compersapoles }\end{array}$ & 2 \\
\hline $\begin{array}{l}\text { Conrencional. Agja } \\
\text { em pepís }\end{array}$ & \multirow{2}{*}{$\begin{array}{l}\text { Coodemaçäa das } \\
\text { perspectivas do } \\
\text { obsurvador e } \\
\text { participtente }\end{array}$} & 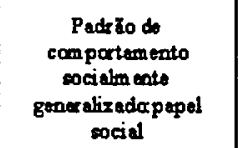 & 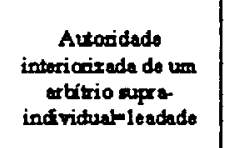 & \multirow{2}{*}{$\begin{array}{l}\text { Deres versess } \\
\text { indina çấ }\end{array}$} & $\begin{array}{l}\text { Perepectiva } \\
\text { do grupo } \\
\text { primério }\end{array}$ & Conformidudo a paptis & 3 \\
\hline $\begin{array}{l}\text { Integrefảo gri ada } \\
\text { por narmas }\end{array}$ & & $\begin{array}{c}\text { Peptis rocialmente } \\
\text { Bener alizador istem a } \\
\text { do normas }\end{array}$ & $\begin{array}{c}\text { Autoridade } \\
\text { intericcisade da } \\
\text { rontade coletive } \\
\text { impessoal-legim idade }\end{array}$ & & $\begin{array}{l}\text { Perpectiva } \\
\text { de um } \\
\text { coletivo }\end{array}$ & $\begin{array}{l}\text { Conformidade co } \\
\text { istema de norm as } \\
\text { oxistontes }\end{array}$ & 4 \\
\hline \multirow{2}{*}{$\begin{array}{l}\text { Pó. } \\
\text { canrencional-Disaux } \\
\text { so }\end{array}$} & \multirow{2}{*}{$\begin{array}{l}\text { Intoraçäo das } \\
\text { perspoctivas do falente } \\
\text { odo mundo }\end{array}$} & $\begin{array}{c}\text { Regra pera } 0 \text { exase de } \\
\text { normerpainctpio }\end{array}$ & \multirow[b]{2}{*}{$\begin{array}{l}\text { Validez ideal ressess } \\
\text { ratider social }\end{array}$} & \multirow[b]{2}{*}{$\begin{array}{l}\text { Autonomia verous } \\
\text { Heteronomia }\end{array}$} & $\begin{array}{c}\text { Perpective } \\
\text { de } \\
\text { pincipios }\end{array}$ & {$\left[\begin{array}{c}\text { Orientayjo em funfara do } \\
\text { principios de justiça }\end{array} \mid\right.$} & 3 \\
\hline & & 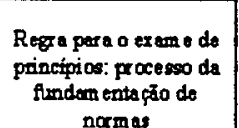 & & & $\begin{array}{l}\text { Pergoectiva } \\
\text { procedur il }\end{array}$ & 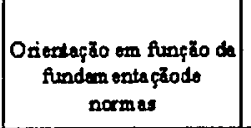 & 6 \\
\hline
\end{tabular}

FONTE: HABERMAS 1989, P. 201-

O estádio pós-convencional é o que estabelece o conceito da capacidade de agir. É neste estádio que o mundo das relações ordenadas é moralizado:

"O conceito de legitimidade das normas de ação é decomposto nos componentes do reconhecimento factual e da qualidade de ser digno de reconhecimento. A essas diferenciações nos conceitos da norma e da validez deontológica corresponde uma diferenciação no conceito do dever; agora, o respeito à lei não serve "per se" como motivo ético. À heteronomia, isto é, à dependência de normas existentes, opõe-se a exigência de que o agente, ao invés da validez social de uma norma, erija ao contrário a sua validade em princípio de determinação de seu agir" (HABERMAS 1989, p. 196).

Assim, o agir moral passa a significar o agir regulado por normas no qual o agente se orienta por pretensões de validez examinadas reflexivamente. A moral fundamentada na ética do discurso revela então um "ponto de vista moral" orientado pela reciprocidade na troca de papéis da fala discursiva que pretende assegurar a participação eqüitativa de todos os envolvidos na argumentação, sem coação e em um entendimento mútuo lingüístico. 


\section{PROCEDIMENTOS METODOLÓGICOS}

A metodologia do estudo é de cunho qualitativo, desenvolvida através da análise sistemática e comparativa de matérias, artigos e cartas de leitores na mídia em papel e fundamentada no estudo de estádios morais segundo a lógica do desenvolvimento de Habermas.

Habermas, discutindo que o entendimento em alguns documentos não é nenhuma operação científica neutra e, que quem quer compreendê-los traz à tona a sua subjetividade em um processo de entendimento com o fim de reconhecer-se-no-outro, recupera um trecho da exposição de Jacob Grimm publicado em Debates dos germanistas Veshandlungen der Germanisten, Fankfurt am Main, 1847.

"A Química e a Física servem a ele como exemplos de ciências exatas, baseadas no cálculo, que apreendem a natureza como um mecanismo, decompõem-na e a montam novamente tendo em vista fins técnicos. De modo totalmente diverso operam as ciências "inexatas" que - graças a um ânimo [Gemüt] sensível, formado com sutileza ("a uma disposição rara de naturezas singulares") - penetram na multiplicidade orgânica e no interior da criação histórica da humanidade. Elas se caracterizam não pela "alavanca e invenções que geram admiração e amedrontam o gênero humano, mas antes, pelo valor e dignidade dos seus objetos: "O humano na linguagem na poesia, direito e história está-nos mais próximo do coração que os animais, plantas e elementos". (Cf. HABERMAS 2001, p. 11-12)

MINAYO (1992, p. 253), em seu livro "O desafio do conhecimento: pesquisa qualitativa em saúde", define as metodologias qualitativas como aquelas capazes de incorporar a questão do significado e da intencionalidade como inerentes aos atos, às relações e às estruturas sociais e desenvolve uma reflexão teórico-metodológica visando demonstrar o caráter científico desta abordagem.

A utilização desta alternativa metodológica explica-se pela natureza dialógica da investigação onde pretende-se refletir a relação leitor, mídia e ética discursiva. Existe a necessidade de explicitar os textos em pauta, articulando-os aos contextos específicos de 
cada autor e, assim, tentar compreender os valores, intenções, disposições e sentimentos destes em um dado momento histórico.

As fontes jornalisticas escolhidas - Folha de São Paulo (FO) e O Estado de São Paulo (OE), foram analisadas no periodo de 1996 - 2001. Cada uma guarda caracteristicas diferenciadas. A FO se apresenta como um jornal a serviço do leitor e que não esconde informação, mantendo uma proposta de linha editorial crítica, apartidária e pluralista. Por outro lado, o OE assegura ter compromisso com a liberdade e a independência e a verdade e conciliar harmonicamente a tradição e a modernidade. Com respeito ao leitor, o $\mathrm{OE} \mathrm{diz}$ ser o intermediário entre o fato ou fonte de informação e, portanto, como seu intérprete se sente no dever de publicar toda denúncia fundamentada que the chegue ao conhecimento, pois o cidadão merece ser defendido. Para a FO o leitor é quem delega ao jornal a tarefa de investigar os fatos, recolher material jornalístico, editar e publicar como delegação de um mandato. ${ }^{36}$

Segundo dados fornecidos pelas empresas o perfil dos leitores ${ }^{37}$ mantém proporção entre os sexos: $50 \%$ de homens e $50 \%$ de mulheres para a FO e $53 \%$ e $47 \%$ respectivamente para OE. Quanto à faixa etária observamos para FO $32 \%$ até 29 anos, $36 \%$ na faixa de $30 / 49$ anos e $32 \%$ para os com 50 anos e mais; no OE $40 \%$ até 29 anos, $39 \%$ entre $30 / 49$ anos e $21 \%$ para 50 anos e mais. $O$ grau de escolaridade está distribuído para a FO em $12 \%$ ensino fundamental, $28 \%$ ensino médio e $43 \%$ ensino superior enquanto para OE observa-se $19 \%, 39 \%$ e $42 \%$ na mesma seqüência de níveis (a FO fornece também $13 \%$ cursando pós-graduação). Existe um predomínio das classes sociais A e B em ambos periódicos: FO $42 \%$ classe A, $43 \%$ classe B e $14 \%$ classes C/D; OE $29 \%$ classe A, $49 \%$ classe $\mathrm{B}$ e $22 \%$ classe $\mathrm{C} / \mathrm{D}$ sendo que a renda familiar mensal distribui-se para FO em $17 \%$ até 10 salários mínimos, $41 \%$ de 10 a 30 s.m. e $36 \%$ acima de 30 s.m.; OE $30 \%$ até 10 salários mínimos, $33 \%$ de 10 a 30 s.m. e $11 \%$ acima de 30 s.m.

Os jornais fornecem suas publicações através de bancos de dados gerados pelos seus sítios oficiais. Os bancos são semelhantes na forma de busca e, do arrolamento

\footnotetext{
${ }^{36}$ estas informações foram retiradas do "Manual geral da redação da Folha de São Paulo" (Folha de São Paulo 1987, p. 27-36) e do "Manual de redação e estilo de O Estado de São Paulo" ( O Estado de São Paulo 1990, p. 15-82).

${ }^{37}$ Os dados fornecidos pelas duas agências estão distribuidos de formas diferentes, foi feita aproximação de alguns dados para ser possivel algumas comparações.
} 
primeiro, estabeleceu-se como o descritor mais indicado para ambos: "saúde and ética"38 (outras expressões acumulavam temas que não se referiam ao objeto). Da leitura dos artigos obtidos extraiu-se as ocorrências (pela redação dos periódicos) quanto aos temas éticos discutidos, a ética em discussão no espaço de opinião do leitor e varredura de alguns assuntos polêmicos ocorridos no período investigado.

O mecanismo detectado indica ser a mídia propositora dos assuntos relacionados à ética em saủde, o que provocava a reação dos leitores, considerando-se ser esta a maneira fundamental para que a compreensão do comportamento discursivo investigado revelasse qual o entendimento de seus colocutores sobre essa questão.

A partir dos eventos levantados, estudou-se as cartas publicadas no período que apresentaram reflexões e contra-reflexões à semelhança do discurso falado, observando os aspectos de reversibilidade, universalidade e reciprocidade já discutidos no capítulo anterior. Dessa forma destacou-se para estudo grupos de reflexões determinados por um dado conjunto de artigos e cartas.

Os grupos dialógicos conduziram à leitura de artigos e matérias dos jornais publicados à época permitindo a delimitação e reconhecimento do momento histórico, podendo-se assim estabelecer: a) a relação de realidade externa daquilo que é percebido; b) a relação de realidade interna daquilo que o falante quer expressar enquanto intenções próprias; c) a relação com uma realidade normativa daquilo que se reconhece social e culturalmente.

$\mathrm{Na}$ seqüência, as falas do grupo discursivo de leitores foram contrapostas com o quadro de estádios de interação, perspectivas sociais e estádios morais de Habermas (Quadro 2). As conversações, respeitando a hierarquização dos tipos de ação segundo a lógica do desenvolvimento de que as estruturas cognitivas nas passagens de um estádio para ou outro não são substituídas e sim reorganizadas, foram analisadas nos três níveis cognitivos - pré-convencional, convencional e pós-convencional; investigando transversalmente, as características dos vários estádios de juízo moral para cada falante: as estruturas de perspectivas, as estruturas da expectativa de comportamento, conceito de autoridade, conceito de motivação e as perspectivas sociais.

\footnotetext{
${ }^{38}$ Para o buscador do jornal O Estado de São Paulo, as palavras saúde e ética não foram acentuadas, pois este não aceita acentos ou cedilhas.
} 
QUADRO 2 - ESTÁDIOS DE INTERAÇÃO, PERSPECTIVAS SOCIAIS E ESTÁDIOS MORAIS

\begin{tabular}{|c|c|c|c|c|c|c|c|}
\hline \multirow{2}{*}{\begin{tabular}{|c|}
$\begin{array}{l}\text { Estrumuras } \\
\text { cogritivas }\end{array}$ \\
Tigos de ecio \\
\end{tabular}} & \multirow{2}{*}{$\begin{array}{l}\text { Estruteses do } \\
\text { perpertiras }\end{array}$} & \multirow{2}{*}{$\begin{array}{l}\text { Estrubre de expectativa } \\
\text { de conpartem ento }\end{array}$} & \multirow{2}{*}{ Conceito de autoridede } & \multirow{2}{*}{$\begin{array}{l}\text { Conceito do } \\
\text { noctivef̧ico }\end{array}$} & \multicolumn{2}{|c|}{ Parspectivas woriais } & \multirow{2}{*}{$\begin{array}{l}\text { Entídios } \\
\text { do } \\
\text { juiso } \\
\text { madi }\end{array}$} \\
\hline & & & & & Petspectire & Reprosentefoto de justipa & \\
\hline Pro-convencional: & \multirow{3}{*}{$\begin{array}{l}\text { Conex to enciproce do } \\
\text { perpectivas de efio }\end{array}$} & \multirow{3}{*}{$\begin{array}{l}\text { Padrăo do } \\
\text { compartanento } \\
\text { perticuler }\end{array}$} & \multirow{3}{*}{ 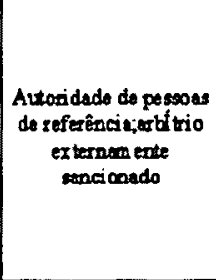 } & \multirow{3}{*}{ 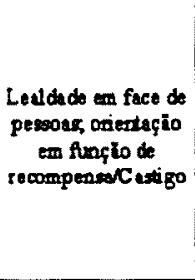 } & \multirow{3}{*}{$\begin{array}{l}\text { Pex spectiva } \\
\text { egocênirica }\end{array}$} & \multirow[b]{2}{*}{$\begin{array}{l}\text { Complean entariedado de } \\
\text { arden o obeditncie }\end{array}$} & \multirow[b]{2}{*}{1} \\
\hline $\begin{array}{l}\text { Interaçäo goremada } \\
\text { por watoridado }\end{array}$ & & & & & & & \\
\hline $\begin{array}{l}\text { Cooperscäo } \\
\text { governeda po } \\
\text { interesse }\end{array}$ & & & & & & $\begin{array}{l}\text { Sim tria des } \\
\text { compensengoes }\end{array}$ & 2 \\
\hline $\begin{array}{l}\text { Comventionalisgi } \\
\text { om peptie }\end{array}$ & \multirow{2}{*}{$\begin{array}{l}\text { Coodernaglo das } \\
\text { perspectives do } \\
\text { obserradore } \\
\text { partiapante }\end{array}$} & 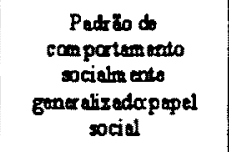 & 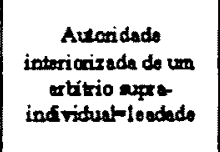 & \multirow{2}{*}{ 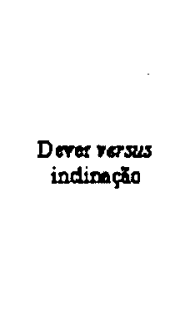 } & $\begin{array}{l}\text { Ferpetive } \\
\text { do grupo } \\
\text { primério }\end{array}$ & Conformidado a pequis & 3 \\
\hline $\begin{array}{l}\text { Integerto gieda } \\
\text { par normes }\end{array}$ & & 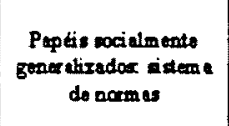 & $\begin{array}{l}\text { Autoridade } \\
\text { interiocizeda ds } \\
\text { rontede ed otive } \\
\text { impersoal=legimidede }\end{array}$ & & $\begin{array}{l}\text { Perepodiva } \\
\text { de un } \\
\text { edetion }\end{array}$ & $\begin{array}{c}\text { Conformidade to } \\
\text { itsema de nocm as } \\
\text { existentes }\end{array}$ & 4 \\
\hline \multirow{2}{*}{$\begin{array}{l}\text { Pós: } \\
\text { econvenciond:Diear } \\
10\end{array}$} & \multirow{2}{*}{ 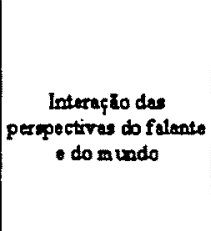 } & $\begin{array}{l}\text { Regra para o exeme do } \\
\text { normex principio }\end{array}$ & \multirow[b]{2}{*}{$\begin{array}{l}7 \text { alider ideal verses } \\
\text { valider encial }\end{array}$} & \multirow[b]{2}{*}{ 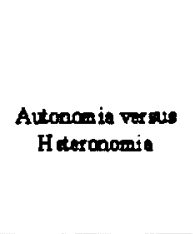 } & $\begin{array}{l}\text { Per apectiva } \\
\text { de } \\
\text { priectpion }\end{array}$ & $\begin{array}{l}\text { Orientaçio em funçio de } \\
\text { pringipios de justi̧a }\end{array}$ & 5 \\
\hline & & $\begin{array}{c}\text { Rega pera o exume de } \\
\text { principios: grocesso de } \\
\text { fundem enta ģấo do } \\
\text { normes }\end{array}$ & & & $\begin{array}{l}\text { Perpectiva } \\
\text { procedural }\end{array}$ & $\begin{array}{c}\text { Orientagto em funçlo de } \\
\text { fundem eniafitod: } \\
\text { nermas }\end{array}$ & 6 \\
\hline
\end{tabular}

FONTE: HABERMAS 1989, P. 201-

Em sintese, os passos de investigação dispõem-se em: a) identificação de situação de diálogo; b) ordenação e descrição do momento histórico; c) determinação de nível de tipo de ação e estádio de juízo moral; d) explicitação de estruturas de perspectivas: conexão recíproca eu-tu, coordenação de observador e participante, interação do falante e do mundo; e) explicitação de perspectivas sociais: egocêntrica, grupo primário, coletivo, princípios e procedural com suas respectivas representações de justiça: complementaridade de ordem e obediência, simetria de compensações, conformidade de papeis, conformidade ao sistemas de normas existentes, orientação em função de princípios de justiça e orientação em função das normas e f) identificação dos conceitos de autoridade e de motivação investido pela fala do sujeito.

À guisa de exercício, considere-se o seguinte caso, excluído do escopo principal da análise deste trabalho. No dia 28 de dezembro de 2002, a FO publicou reportagem com referência a divulgação pela empresa Clonaid, da seita dos raelianos, do nascimento do primeiro clone humano. ${ }^{39}$ A reportagem trazia em seu bojo um conjunto de informações

\footnotetext{
${ }^{39}$ Em 02/10/2002 o mesmo jornal já havia noticiado que a empresa teria informado de gestações viáveis de clones humanos
} 
sobre clonagem, seita raeliana e a empresa Clonaid. Somava-se ainda um artigo opinião sobre o assunto e uma análise feita pelo editor de ciência da FO.

Como de costume, na presença de assuntos polêmicos, a edição trazia um conjunto de opiniões sobre o assunto de representantes da comunidade cientifica e religiosa o qual analisaremos para exemplificar a aplicação do quadro de desenvolvimento e destacar algumas tendências dentro dos discursos particulares. Da comunidade científica, registraram-se os seguintes depoimentos:

SEVERINO ANTINORI, ginecologista italiano que anunciou para o começo do ano que vem o nascimento de um clone:

"[A notícia] me faz rir e ao mesmo tempo me desconcerta, porque cria confusão entre as pessoas que querem fazer pesquisa científica séria e as que não querem. Nós continuamos o nosso trabalho científico, sem fazer anúncios. Eu não participo dessa... corrida".

VOLNEI GARRAFA, presidente da Sociedade Brasileira de Bioética:

"Acho isso de uma irresponsabilidade total. Se eles conseguiram um clone, o que eu duvido, porque a tecnologia não está suficientemente desenvolvida, o que fizeram com os embriōes em excesso e os [fetos] aberrantes? Não consigo entender, a não ser por sensacionalismo, qual é a utilidade da clonagem reprodutiva, quando ainda há muito o que avançar no campo da fertilização "in vitro". Isso fere todo e qualquer aspecto ético da pesquisa e do desenvolvimento tecnológico".

ISAIAS RAW, bioquímico, presidente da Fundação Butantan:

"Se é verdade, ia acontecer mesmo. Se era viável na [ovelha] Dolly, é viável no homem. Mas qual é a consequência dos monstros que eventualmente vamos criar? Há problemas como o envelhecimento precoce, por exemplo. Você não tem como saber a curto prazo, porque algumas doenças hereditárias só aparecem depois de uma certa idade".

LYGIA DA VEIGA PEREIRA, geneticista, professora do Instituto de Biociências da USP:

"O mais assustador é que pode ser verdade. Qualquer clínica de fertilização "in vitro" bem equipada está capacitada para fazer isso. A questão é o preço biológico da clonagem: quantos fetos malformados, quantos abortos em estágio avançado. Nós aprendemos que a clonagem é um fracasso em mamíferos, e até hoje ninguém conseguiu clonar um primata. Você tem de 
acreditar na palavra dessa gente, que faz as coisas absolutamente à revelia da comunidade científica internacional".

CRODOWALDO PAVAN, geneticista, ex-presidente do CNPq:

"É uma irresponsabilidade. Um absurdo. Essas pessoas estão fugindo da crítica do resto da comunidade científica. Não sou contra a clonagem humana, mas estão fazendo como se fosse farra de fim de ano. Daqui a pouco vamos ter "paraísos clonais", como existem os paraisos fiscais. Ninguém demonstrou que isso pode ser feito com segurança".

GLENN McGEE, bioeticista da Universidade da Pensilvânia, EUA:

\begin{abstract}
"É uma bobagem. Acho muito, muito improvável que tenham feito um clone. Estão roubando dinheiro de vítimas inocentes. Os problemas técnicos com macacos são tão grandes que ninguém conseguiu cloná-los. E eles são primatas, como nós. Boisselier não disse nada sobre quantas falhas aconteceram em estágios iniciais do processo. Não disse como obteve o consentimento esclarecido das voluntárias. E trouxe um jornalista de quem ninguém nunca ouviu falar para comprovar o feito. No mínimo, esse anúncio traz um problema enorme para o debate sobre células-tronco e clonagem terapêutica".
\end{abstract}

Os pronunciamentos da comunidade científica mantiveram o discurso em niveis pré-convencional - estádio 2 ( cooperação governada por interesses) e convencional estádio 3 (agir em papéis) - “...Acho isso de uma irresponsabilidade total.... Isso fere todo e qualquer aspecto ético da pesquisa e do desenvolvimento tecnológico". ) O estádio 3 foi destacado, na sua maioria, em conexão recíproca de perspectivas de ação (eu - tu ); com perspectiva egocêntrica - “.....Nós continuamos o nosso trabalho cientifico, sem fazer anúncios. Eu não participo dessa... corrida"; perspectiva grupo primário quando autoreferem a própria comunidade científica e perspectiva de coletivo somente na fala de Glenn Mcgee - "..... Estão roubando dinheiro de vítimas inocentes....... Não disse como obteve o consentimento esclarecido das voluntárias." e representação de justiça em simetria de compensações, ou seja, ação por interesse da própria comunidade científica “...... Você tem de acreditar na palavra dessa gente, que faz as coisas absolutamente à revelia da comunidade cientifica internacional."; “.... Essas pessoas estão fugindo da crítica do resto da comunidade cientifica."; “.....Não consigo entender, a não ser por sensacionalismo, qual é a utilidade da clonagem reprodutiva, quando ainda há muito o que avançar no campo da fertilização "in vitro"."

Já entre os representantes da comunidade religiosa, foram coletadas duas falas: 
LEVI CORRÊA DE ARAÚJO, pastor da $1^{\mathrm{a}}$ Igreja Batista de Santo André:

"Não há por que se assustar com a clonagem. Ela não impede a minha fé. O desenvolvimento da ciência é algo absolutamente oriundo da capacidade que Deus deu ao ser humano. E quem dá o sopro da vida não é o cientista, e sim Deus. O clone é outro ser".

EDUARDO RODRIGUES DA CRUZ, professor do Departamento de Teologia e Ciências da Religião da PUC de São Paulo:

"Do ponto de vista da moral, não só da igreja, clones humanos são inadmissíveis. Então, a Igreja Católica condenaria e tentaria evitar que essa experiência se repetisse. Mas, se um clone nascesse, ele teria o estatuto de qualquer ser humano. A condenação aos pais não é extensível à criança".

Tais pronunciamentos mantiveram o discurso em nível préconvencional/convencional - estádio 1, 2, 3: agir em papéis com perspectivas de observador e participante e padrão de reconhecimento de papel social com noção de autoridade interiorizada de um juízo supra-individual (lealdade) é o estádio mais alto observado. Denota-se um discurso sem questionamentos transparecendo que os deveres estão encaixados nos hábitos concretos da vida (dever versus inclinação) - "Do ponto de vista da moral, não só da igreja, clones humanos são inadmissiveis"; onde questões como estas não são respondidas a partir delas mesmas mas de um ponto externo cosmológico "O desenvolvimento da ciência é algo absolutamente oriundo da capacidade que Deus deu ao ser humano". Interessante notar a relação de lealdade em face de pessoas (recompensa castigo) com a transição de uma fala de estádio 1 para estádio 2 na relação de representação de justiça - "Então, a Igreja Católica condenaria [interação governada por autoridade, ordem e obediência] e tentaria evitar que essa experiência se repetisse. Mas, se um clone nascesse, ele teria o estatuto de qualquer ser humano" (simetria de compensações, interesse). 


\section{RESULTADOS}

A análise geral dos dois jornais demonstrou as características próprias de cada linha editorial, assim como o comportamento reativo dos leitores de Folha da São Paulo e de O Estado de São Paulo revelou uma conversação diferenciada. As cartas da FO apresentam maior propensão, quantitativa e qualitativa de colóquio, ou melhor, a forma de tratar os assuntos "polêmicos" pela redação da FO tende a gerar uma discussão mais prolongada de maneira a manter uma articulação enriquecida entre leitor/redação e interleitores. Evidenciar-se-á tal aspecto ao longo da apresentação dos casos.

A diversidade dos temas tratados inclui: criação da Comissão Nacional de Ética em Pesquisa (CONEP), pesquisas médicas, doação compulsória de órgãos para transplante, eutanásia, legalização do aborto, direitos dos pacientes, clonagem, planos de saúde, drogas, dupla porta no atendimento dos serviços de saúde e controle de medicamentos. Não houve domínio de proposição para os temas por qualquer um dos pontos observados - redação e leitor, ou seja nenhum desses foi provocador dos assuntos e sim os fatos ocorridos na ocasião é que, quando noticiados, despertaram as interlocuções. O mesmo não aconteceu quando criada a situação de discurso pois, neste momento, percebe-se a presença de alguns leitores incitando argumentações e contra-argumentações.

A seguir apresento os resultados obtidos por blocos temáticos dentro do conjunto de cartas de cada jornal. O material obtido está disposto cronologicamente ${ }^{40} \mathrm{em}$ anexo I e II deste trabalho. A análise está restrita às cartas que seguiram uma lógica de argumentação com outras cartas e/ou artigos e reportagens dos jornais, portanto o conjunto de cartas sobre o tema não identificado com o outro da interlocução - o jornal ou um leitor, não foi submetida à análise dada a dificuldade de se estabelecer, com certeza, sua pretensão de validez: verdade, correção e sinceridade.

\footnotetext{
${ }^{40}$ a cronologia respeita as datas das cartas dos leitores. Os artigos/reportagens aos quais eles se remetem foram aproximados do falante independente da data de publicação.
} 


\section{o aborto}

$\mathrm{O}$ aborto foi uma questão fortemente referenciada no período investigado. Em um primeiro momento concentram-se cartas pela ocasião da votação sobre o projeto de lei 20/91 (PL 20/91), apresentado pelo deputado Eduardo Jorge (PT-SP) e deputada Sandra Starlin (PT-MG). Este determinava que os serviços da rede pública deveriam atender e executar aborto em casos de estupro.

O projeto referenciava a situação estabelecida no Código Penal Brasileiro, do Decreto - lei $\mathrm{n}^{\circ} 2848$ de $07 / 12 / 1940$, vigente na ocasião, procurando regulamentar e viabilizar o disposto no inciso $\mathrm{II}^{41}$

“art. 128 - Não se pune o aborto praticado por médico:

Aborto necessário

I - se não há outro meio de salvar a vida da gestante;

Aborto no caso de gravidez resultante de estupro

II- se a gravidez resulta de estupro e o aborto é precedido do consentimento da gestante ou, quando incapaz, de seu representante legal.

A complexidade da matéria envolvida e suas implicações sociais e religiosas provocou importante polêmica. Outras propostas para criação deste direito já haviam sido feitas, inclusive a de permissão de aborto em casos de má formação."

A igreja, representada pela Conferência Nacional dos Bispo do Brasil - CNBB, desde 1996 declarava-se contrária e reiterava algumas de suas conviç̧ões: a indissolubilidade do casamento, a relação entre amor e procriação, a imoralidade das relações sexuais antes do casamento, o aborto, a masturbação e os métodos anticoncepcionais. Em 1997 a CNBB iniciou campanha sistemática contra o projeto e em 2 de outubro desse mesmo ano, com a visita do papa João Paulo II ao Brasil, acirraram-se as discussões principalmente após a declaração da primeira dama Ruth Cardoso em defesa da regulamentação do aborto no dia anterior à sua chegada.

\footnotetext{
${ }^{41}$ este assunto está contido na Parte Especial do código - dos crimes contra a pessoa e em especial dos crimes contra à vida. À época da revisão em 1941 já trazia uma observação: "Militam em favor da exceção razões de ordem social e individual, a que o legislador penal não pode deixar de atender", o que pode ser consultado em Brasil. Código penal. Organização dos textos, notas remissivas e índices por Juarez Oliveira. $6^{a}$ ed. São Paulo: Saraiva, 1991, p. 23-24 e p. 74.
} 
$\mathrm{Na}$ realidade, este assunto permeia quase todo o período. Durante o ano de 1996 o projeto esteve aguardando a aprovação da Comissão de Constituição e Justiça e de Redação da Câmara sobre a sua constitucionalidade e juricidade, recebendo parecer favorável no mês de setembro. Dois meses após, em 5 dezembro, um grupo de parlamentares de oposição ao projeto, entrou com pedido de recurso contra a decisão da Comissão, impedindo e protelando a sua tramitação.

No decorrer da segunda metade do período, a descriminação do aborto foi aprovada pelo plenário da $11^{\text {a }}$ Conferência Nacional de Saúde (CNS), órgão deliberativo do Ministério da Saúde cujas decisões tornam-se diretrizes para a condução de políticas públicas na área da saúde. ${ }^{42}$ Isto fez emergir a discussão em maior amplitude.

Situações de estupro em crianças também provocaram o diálogo em todo o período. Narração dos casos e determinações dadas pelos juízes implicados foram noticiados pelos dois jornais ajudando na reflexão sobre o aborto legal.

\section{Leitores e discursos}

A análise seguinte apresenta discussões tanto entre autores representantes da igreja, do judiciário, profissionais da saúde, como de organizações não-governamentais e do leitor-cidadão dos dois periódicos.

\section{DISCURSO 1}

O primeiro diálogo (Anexo I, p. 1-2) desenrola-se a partir de um editorial do jornal Folha de São Paulo que declara ter o então cardeal-arcebispo d. Paulo Evaristo Arns, defendido o não-desenvolvimento da gravidez nos casos de estupro. No dia seguinte a FO divulgou que a assessoria de imprensa da Arquidiocese de São Paulo referiu ser o pronunciamento d. Paulo, não uma defesa do aborto em caso de estupro mas o entendimento de que a mulher estuprada deve de imediato buscar um ginecologista para efetuar uma lavagem uterina evitando dessa forma que a concepção ocorra.

Identifica-se uma pretensão de verdade controversa que é argüida pelo leitor Antonio Ribeiro de Almeida

"A Folha declarou que o cardeal Arns é favorável a que mulheres vitimas de estupro façam aborto. Logo em seguida o cardeal, por

\footnotetext{
${ }^{42}$ lembre-se aqui, seu importante papel no período pré-constituinte para as determinações de assuntos relativos à saúde promulgados na Constituição de 1988.
} 
sua assessoria, declarou que não era bem assim e que continuava fiel à posição da igreja sobre o problema. Quem mentiu? A Folha ou o cardeal?" FO-04/01/96

Tanto leitura do editorial e a transcrição da entrevista dada pelo arcebispo falham por pretensão de correção. Enquanto o editorial refere

"É no mínimo corajosa a atitude do arcebispo de São Paulo, dom Paulo cardeal Arns, de defender o não-desenvolvimento da gravidez nos casos de estupro." FO-22/12/95

a transcrição é assim apresentada em nota da redação

"É este o conselho que devemos dar a uma moça estuprada: vá de imediato ao ginecologista e faça o tratamento, não espere a criança se formar no seu seio". No dia seguinte, sem negar 0 conteúdo da entrevista, d. Paulo afirmou que o tratamento a que se referia era uma lavagem intra-uterina para impedir a concepção." FO- 12/01/96

Verifica-se a presença de uma propensão, tanto na leitura do editorial quanto na gravação do cardeal, de uma conversação ambígua que leva o leitor Antonio a entrar em diálogo com o jornal. Este coloca-se no estádio moral pós-convencional, pois racionalmente aplica uma regra para o exame da situação - a credibilidade de duas instituições.

A carta publicada despertou a reflexão do leitor Juraci Josino Cavalcante que, em FO-12/01/96, frente a uma fala clara orientada em princípios de justiça- estádio 5 , se vê obrigado a exigir da FO um comportamento que atenda a estes princípios.

\section{DISCURSO 2}

Para os leitores de O Estado de São Paulo, dois artigos, um de d. Lucas Moreira Neves, cardeal arcebispo de Salvador e presidente da CNBB, "Malgrado a violência, a vida", (Anexo II, p. 3-4) e outro, do deputado federal José Genoíno (PT-SP), "Não se pode punir em nome de concepções morais, religiosas ou filosóficas", (Anexo II, p. 1-2) também fazem alusões à declaração de d. Paulo relatado no discurso 1.

D. Lucas conclui o seu texto em um parágrafo final opinando sobre este assunto

\footnotetext{
"Finalmente, acato, sem reserva, a orientação de bispos e moralistas católicos sobre a lavagem vaginal ou intra-uterina com o fim, não de eliminar um zigoto ou embrião e, portanto, um ser vivo, mas de criar uma barreira à concepção. Registro, contudo, a opinião de uma das maiores autoridades do mundo
} 
no campo da bioética. Segundo o professor Elio Sgreccia, exdiretor do Instituto de Bioética da Faculdade de Medicina da Universidade Católica Gemelli, de Roma, hoje, vice-presidente do Conselho Pontificio para a Família, instantes depois do estupro, dá-se ou não a concepção. Portanto, a lavagem ou será supérflua, se não houve a fecundação, ou será abortiva, se houve. Aconteceu essa evolução de 50 anos para cá." OE02/01/96

José Genoíno, faz menção à d. Paulo ao tratar sobre o parecer contrário ao PL 20/91 dado pelo deputado federal Hélio Bicudo

\begin{abstract}
"O parecer do deputado Hélio Bicudo na CCJ, entretanto, nega acolhimento ao projeto de lei dos deputados. Além de admitir a possibilidade do aborto somente no caso de risco de vida da mulher em conseqüência da gravidez e de atribuir a decisão a uma junta médica, independentemente do consentimento da gestante ou de pessoas da família, Hélio Bicudo se pronuncia contrário a todo aborto voluntário, inclusive nos casos de estupro. Ele propõe que o Estado assuma a assistência à gestante e se responsabilize pela vida e pela educação das crianças geradas pelo estupro. Essa posição representa grave retrocesso em relação ao que a legislação brasileira já conseguiu avançar na matéria. Por um lado, quer obrigar as mulheres estupradas a aceitar uma gravidez originada de um ato de violência abominável. Essa imposição, que corresponderia a uma imposição do Estado, resultaria num ato de violência contra a consciência e contra o direito da mulher de dispor de seu corpo tão grave quanto a violência do próprio estupro. Por outro lado, a solução proposta por Bicudo - de o Estado criar e educar as crianças geradas pelo estupro - resultaria na constrangedora situação de a sociedade visualizar os "filhos do estupro", abrindo espaços para discriminações com suas graves conseqüências psicológicas e sociais. Registre-se que o cardeal-arcebispo de São Paulo, dom Paulo Evaristo Arns, num ato de coragem que Ihe é peculiar, admitiu, recentemente, a possibilidade do aborto nos casos de estupro." OE-12/01/96
\end{abstract}

$\mathrm{O}$ artigo de d. Lucas transparece, como ele próprio refere, sua função de magistério da Igreja. Ele discorre sobre diversas situações de estupro e o papel do sacerdote em apoiar e orientar a decisão da mulher em não abortar. $\mathrm{Na}$ realidade, o artigo é às pessoas que professam a fé cristã com destaque para o aspecto inviolável da vida em um discurso transcendental

"Árduo, não porque o tema, abordado por dever de consciência, seja obscuro, e o articulista não saiba o que dizer. Ao contrário, a vida e a sacralidade da vida, objetos do artigo, são o que há de mais claro e quem só escreve para transmitir o magistério da Igreja sabe perfeitamente o que vai dizer. (...) Entretanto, a 
moral evangélica, mesmo diante do caso dramático da mulher violentada e grávida, não cessa de afirmar: 'A vida é sagrada. A vida é o que mais se aproxima do Absoluto de Deus. Por isso, a vida é inviolável desde o instante da concepção até o derradeiro suspiro. Ninguém tem o poder de suprimir a vida humana de um inocente, ainda mais quando é pequenino e indefeso. Portanto, o aborto não é moralmente lícito, nem após um estupro'." OE02/01/96

e, ao final, demonstra o seu apoio à proposta do deputado Hélio Bicudo

"Li e ouvi na mídia reações iradas à proposta do deputado Hélio Bicudo, do PT de São Paulo: que o Estado assuma a educação das crianças geradas por estupro que as mães, com liberdade $e$ responsabilidade, decidem ter, mas não estão em condições de educá-las. Tal proposta não pretende condenar essas crianças aos institutos estatais de reeducação de crianças abandonadas, tais como os conhecemos e os tememos. Pretende que, com o amparo do Estado, as crianças nascidas do estupro encontrem uma casa-lar, uma família alternativa que as adote ou soluções similares que garantam um ambiente de ternura e afeto para quem de afeto e ternura terá especial necessidade." OE$02 / 01 / 96$

Enfim, ele reforça as recomendações difundidas pela igreja católica e a CNBB, ou seja, a partir de um horizonte de um todo concebido do ponto de vista da história da salvação cosmológica onde os deveres estão encaixados nos hábitos concretos da vida dever versus inclinação, e também está localizado no estádio 4/convencional, pois d. Lucas tem uma perspectiva de um coletivo: o conjunto de pessoas católicas que devem agir em conformidade com as suas regras mas que não trabalha a relação autonomia versus heteronomia.

Por outro lado, o artigo de Genoíno convoca a sociedade a participar do processo de decisão de encaminhamento para as questões do aborto

"A Câmara dos Deputados e a Comissão de Constituição e Justiça
(CCJ) serão obrigadas a se pronunciar, em breve, sobre a
questão do aborto, tema polêmico por conta de suas injunções
morais, religiosas e jurídicas. Ocorre que, atualmente, tramitam
várias emendas e projetos que tratam o assunto de forma global
e parcial. Diante disso, é importante que a sociedade acompanhe
as decisões que serão tomadas para que se possa pronunciar
sobre essa complexa questão, que diz respeito particularmente
às mulheres." OE-12/01/96

Ainda com intuito elucidativo apresenta o rol de projetos a favor do aborto em tramitação no Congresso Nacional contrapostos às emendas e pareceres contrários 
apresentados. A análise das reflexões por ele apresentadas identifica um discurso pósconvencional como pode ser demonstrado no parágrafo a seguir

"Se vivemos numa sociedade democrática e plural, tanto as
posições favoráveis como as posições contrárias à prática do
aborto devem ser respeitadas. As que são contrárias de forma
absoluta não precisam praticá-lo. Mas em nome dessas
concepções não se pode punir ninguém. Não se pode querer
impor uma legislação que faça com que o Estado viole a
consciência, a vontade e a autodisposição do corpo das
mulheres." OE-12/01/96

Denota-se ainda que Genoíno não se confronta com a Igreja, anuindo à idéia de que ela não se contrapõe por preceitos religiosos e sim por direito à vida, ${ }^{43}$ quando ressalta a frase

"Todos os que se pronunciam em favor da manutenção da criminalização do aborto o fazem em nome do direito absoluto à vida." OE-12/01/1996

Do conjunto de cartas relacionadas aos dois artigos, somente uma traz referência a outro leitor e não foi localizada no banco de dados. Todas são datadas em 27/01/96 com a presença de atores vinculados a papéis de oponentes e proponentes. Nota-se um comportamento mais agressivo e irônico dos oponentes ao aborto e portanto ao artigo de d. Lucas. Estas não foram consideradas para a análise, pois estes comportamentos sarcásticos afrontam a pretensão de validez na sua qualidade de correção.

As analisadas trabalham em uma perspectiva social egocêntrica do nível préconvencional e, portanto, em uma perspectiva de ação eu-tu diferencial do comportamento dos leitores do bloco contrário às lógicas não abortivas. (Anexo II, p. 1)

\begin{abstract}
"Pimenta nos olhos dos outros é colírio. Encômios para José Genoíno (13/1). Repúdio ao projeto de Hélio Bicudo, de o governo manter creches para os filhos resultados de estupro. Gostariamos de saber o que faria o sr. Hélio Bicudo se tivesse de enfrentar a gravidez, proveniente de estupro, de uma filha ou neta. Nós que subscrevemos esta somos professoras aposentadas, mães, avós e bisavós. Que o aborto seja um direito
\end{abstract}

\footnotetext{
${ }^{43}$ um dos argumentos usados pela igreja para justificar sua posição contrária ao aborto e identificado quando percorremos o conjunto de correspondências e artigos coletados, é o de que estes não são religiosos e transcendem a isso, pois estão falando do respeito à vida humana.
} 
da mulher. Que o controle de natalidade seja uma coisa séria" OE-27/01/96

"Nós, mulheres conscientes e lutadoras, sabemos que é perda de tempo dirigir energia para a crítica à Igreja Católica e outras. Mas o artigo de dom Lucas Moreira Neves (3/1) é de tamanha crueldade $\mathrm{e}$ insensibilidade que não é possível se calar e ser cúmplice. O conceito de "vida" da Igreja merece reflexões. Sendo o articulista um homem de uma igreja machista, não teria mesmo cultura suficiente para entender o horror que pratica ao declarar que o fruto do estupro deve vir à luz em qualquer caso. D. Lucas, é preciso aprender com o coração o respeito à democracia e, assim, o respeito às mulheres. São elas que devem aceitar ou não o filho gerado pela covardia de uma delinqüência própria de cultura machista." OE-27/01/96

As cartas com argumentos de objeção ao artigo do Genoíno mantém o diálogo na terceira pessoa de um observador participante do nivel convencional.

"Não concordo com o artigo do deputado José Genoíno (13/1), que afirmou que aborto é questão de saúde pública. É uma questão de vida humana. Ou se respeita a vida ou não se respeita. Aborto é assassinato consciente de uma vida humana indefesa. Por outro lado, alegra-me que haja gente de bem e corajosa, como o sr. Hélio Bicudo, defendendo a vida custe o que custar" OE-27/01/96

"Pelos artigos que tenho lido do sr. José Genoíno, confio em suas boas intenções. Mas gostaria de dizer-lhe o seguinte: quando um homem, na sua ação política, prescinde da lei moral (aborto é homicídio, of. o $5^{\circ}$ mandamento), esta ação, embora aparentemente "resolva" problema imediato, é ação de curta raiz e de baixo alcance." OE-27/01/96

"Como sacerdote católico, tantas vezes obrigado pelo ofício de confessor a orientar casos trágicos, agradeço a dom Lucas Moreira Neves pela esplêndida lição em Malgrado a violência, a vida. Se o sr. Euclides Ap. dos Santos não quiser concordar $(4 / 1)^{44}$, lembre, porém, que a Igreja, longe de transformar borboletas em lagartas, está acostumada a fazer de lagarta borboleta (conforme a natureza). E isto desde que seu Fundador, morrendo na cruz, disse ao criminoso que estava a seu lado: "Hoje você estará comigo no paraíso" (LC. 24, 43). Pe. Donato Vaglio, Bragança Paulista." OE-27/01/96

\footnotetext{
${ }^{44}$ esta correspondência não foi localizada no banco de dados do jornal.
} 
DISCURSO 3

A discussão deste bloco desenvolve-se entre representantes do legislativo, os deputados federais: Marta Suplicy (PT-SP), Hélio Bicudo (PT-SP) e Eduardo Jorge (PTSP).

Frente aos posicionamentos de oposição ao aborto de Hélio Bicudo, Marta Suplicy envia carta desaprovativa ao jornal (Anexo I, p. 7). Isto desencadeia duas correspondências: a réplica do criticado e um opinativo de Eduardo Jorge (Anexo I, p. 7).

A carta desencadeante lamenta a argumentação pautada em principios religiosos de Hélio Bicudo.

\begin{abstract}
"Lamento que o companheiro Hélio Bicudo (PT) se paute por fundamentos de sua crença religiosa ao tratar de direitos sexuais. Questões de fé devem ser respeitadas em nivel individual, mas não podem ser transformadas em padrão ao se legislar para o conjunto dos cidadãos e cidadãs." FO-02/07/96
\end{abstract}

Marta, após descrição de sua posição favorável com respeito ao aborto, esterilização e união civil entre pessoas do mesmo sexo, conclui a carta também em ação de nível convencional aqui caracterizado em argumento de legitimidade partidária.

"À vista das discussões havidas no PT sobre os três temas
citados, creio que as posições dos deputados José Genoíno,
Eduardo Jorge e as minhas estão mais de acordo com a
militância e a direção do nosso partido." FO-02/07/96

Por toda a análise, Hélio Bicudo mantém um tipo de ação caracterizada entre préconvencional/convencional. Identifica-se com um juizo moral que varia de uma perspectiva egocêntrica e de grupo primário do estádio $2 / 3$, quando as situações implicam em princípios religiosos, para uma perspectiva de um coletivo com o ponto de vista moral em conformidade de sistemas de normas da Igreja Católica. Para as questões de outra propriedade seu argumento é dado em nível pós-convencional, estádio 5. Esse é um exemplo da idéia de hierarquização dos tipos de ação em conexão com a lógica do desenvolvimento - sentido cumulativo de perspectivas.

Bicudo em FO 03/07/96, responde afastando-se de uma argumentação baseada em preceitos religiosos. Argumenta formalmente pela não união civil entre pessoas do mesmo sexo o que o coloca em uma posição de interação guiada por normas do nível convencional. A fala antecedente à argumentação legal interpõe traços de um conceito de motivação de lealdade em face de pessoas em perspectiva benevolente eu-tu. 
"Pelo contrário, respeito aqueles que optaram por um estilo de vida diferente do meu. Não os discrimino, considerando-os minorias, mas sim pessoas humanas. $E$ entendo que para preencherem suas necessidades patrimoniais sucessórias a lei civil já as abriga, inexistindo necessidade de casamento legal, com papel passado." FO 03/07/96

Por último, tem razão a sua argumentação conclusiva evidenciada em nível pósconvencional decorrente da débil argumentação convencional referida na conclusão da carta de Marta Suplicy.

"Por final, não sei onde e como a conclusão de que as posições profligadas merecem o acordo da militância e da direção do PT." FO 03/07/96

Na terceira e última carta deste bloco, Eduardo Jorge inicia o diálogo com Bicudo na relação eu-tu diferenciando suas perspectivas das dele (estádio 2, pré-convencional). Deste ponto, passa a contextualizar as suas posições coordenando-as às perspectivas de um observador e apontando realidades sociais amplas (estádio 6, pós-convencional).

\begin{abstract}
"Respeito Hélio Bicudo e evito polêmicas com ele, porém: insistir na criminalização do aborto é ser conivente com os nossos indices vergonhosos de mortalidade entre mulheres jovens. Insistir na obstrução a qualquer programa amplo de planejamento familiar é negar uma aspiração universal de homens e mulheres. Insistir na discriminação aos homossexuais é negar a quem pregou o amor ao próximo sem qualquer exceção." FO 07/07/96
\end{abstract}

Neste período, ainda sobre o mesmo tema, foram identificadas duas cartas: uma de apoio ao artigo "Esterilização, aborto e homossexuais" FO-30/6 assinada pelo bispo Raymundo Damasceno Assis, secretário-geral da CNBB _Conferência Nacional dos Bispos do Brasil, FO- 17/07/96 e outra discordando, FO-18/07/96 firmada por Toni Reis e David Harrad. (Anexo I, p. 8)

A primeira não apresenta reflexões sobre o assunto sendo espaço para a campanha de oposição instituída pela CNBB à época e a segunda sugere ser uma reivindicação por direitos iguais e de cidadania de homossexuais. Ambas são moções de apoio não instigando outras reflexões e pelo tal não provocando a continuidade na discussão. ${ }^{45}$

\footnotetext{
45 Algurmas cartas ainda de 1996 (Anexo I, p. 1-15) não foram analisadas por não apresentarem relação dialógica identificada ou relacionada com o tema. À exemplo, a carta FO-09/04/96 relacionada a um artigo de Marcelo Coelho "Comprar revistas de esquerda é ato de teimosia" FO-22/03/96 foge ao tema proposto; a FO-21/05/96, apesar de relacionada à questão aborto trata de uma situação particularizada ao dialogar com FO-08/05/96 "Grupo de católicos defende o aborto" e não provocou os leitores; a carta FO-08/12/96
} 
DISCURSO 4

Este diálogo acontece entre o coordenador do movimento Pró-Vida da Diocese de Anápolis, Goiânia, Luiz Carlos Lodi da Cruz e Anibal Faúndes, professor titular de obstetrícia da Unicamp e presidente da Associação Internacional de Saúde Materna e NeoNatal (Anexo I, p. 13). A primeira não pode ser considerada com pretensão de validez pois a fala

\begin{abstract}
"A partir do dia $1^{\circ}$, uma gestante poderá continuar tendo que esperar horas na fila para ter um atendimento precário, se o desejo for cuidar da saúde do filho. Mas, se o seu desejo for matá-lo, haverá uma equipe multiprofissional especialmente preparada para atendê-la com toda a solicitude. Refiro-me ao 'serviço' de aborto que será inaugurado no mês que vem no atual Hospital Materno-Infantil de Goiânia" FO- 17/02/97
\end{abstract}

não condiz com a verdade. A carta dá a entender que a unidade fará aborto mas a reportagem explica que isto é uma forma de contracepção de emergência

\begin{abstract}
"Uma iniciativa simples da Secretaria Municipal da Saúde e da Delegacia da Mulher de Goiânia transformou a cidade em pioneira no pais no uso da "contracepção de emergência". O serviço consiste em oferecer a mulheres vitimas de estupro uma superdosagem de pilulas anticoncepcionais." FO-23/02/97
\end{abstract}

O professor Aníbal ao se referir à carta de Lodi, amplia a discussão interagindo suas perspectivas de falante com as perspetivas do mundo estabelecendo um discurso pósconvencional com argumentação orientada para a fundamentação de uma nova norma.
"(...)durante meio século, a vítima de estupro só por exceção é atendida nos hospitais públicos, vendo-se obrigada a recorrer ao aborto clandestino. Já que a violência sexual contra a mulher é

\footnotetext{
parabeniza o editorial da FO "Tecnologia e risco" que trata do assunto mas também não dialoga com os leitores; o caso discutido na carta FO-7/10/96 trata de uma observação com respeito à programa de televisão e ainda o caso relativo ao leitor FO-05/12/96 e a reportagem "Justiça começa a autorizar o aborto" de FO01/12/96 que discute a sindrome de Down e a legalização do aborto. O mesmo ocorreu para algumas para $\mathrm{O}$ Estado de São Paulo em um fato ocorrido sobre aborto na Inglaterra onde uma mulher com gravidez gemelar decide abortar um dos fetos alegando-se impossibilitada de criar duas crianças OE-05/08/96e OE -06/08/96. O caso é peculiar, pois não se trata de má formação do feto ou ocorrência de estupro. Apesar disso, não foi assinalado diálogo interleitores e as cartas de leitores levantadas simplesmente opinam sobre o assunto $\mathrm{OE}$ 14/03/96. Ao final da reportagem $O E$-05/08/96 existe uma alusão à destruição de embriões vencidos e uma das correspondências opina sobre este acontecimento. A próxima troca de cartas interleitores já situada no ano de 1997, OE -13/01/97, e assinada por Paulo $\mathrm{F}$. Cunha, não permitiu análise dado que não é uma interação comunicativa, pois não conduz a processos de entendimento por falhar na pretensão de validez. A ambigüidade e ironia de sua escrita torna ininteligivel seu proferimento e impede avaliar verdade, correção e sinceridade na sua fala.
} 
uma realidade incontestável, e que a gravidez dela resultante é uma segunda violência intolerável para a maioria delas, torna-se impostergável encontrar uma forma de responder às necessidades dessas mulheres. O hospital, que anuncia sua proposta de atender esses casos, não está absolutamente aumentando sua carga de trabalho. Pelo contrário: evitará as graves complicações do aborto clandestino, ao mesmo tempo que protege um direito da mulher violentada." FO- 20/02/97

\section{DISCURSO 5}

Em 21/08/97 a Comissão de Constituição e Justiça da Câmara aprovou o PL 20/91, sobre a obrigatoriedade de atendimento pelo Sistema Único de Saúde dos casos de aborto previstos no Código Penal já referido. As cartas analisadas neste bloco derivam das reportagens que FO publicou no dia seguinte sobre o assunto.

O leitor Eduardo Grígolo analisa o fato em uma lógica positivista do tipo se....então: se o aborto é legal então aborto é a legalização da pena de morte (Anexo I, p. 17).

\footnotetext{
"Sobre a decisão da Comissão de Constituição e Justiça da Câmara sobre o aborto: trata-se da 'legalização' da pena de morte. Será que impedir que um ser indefeso viva não é uma violência maior do que o estupro que o gerou?" FO 30/08/97
}

Nesta lógica, Eduardo apresenta um comportamento socialmente generalizado de representação em conformidade com o sistema de normas do estádio 4 mas, o mote tal se dá em uma perspectiva egocêntrica, pois não se identifica uma expansão do posto para o coletivo.

Da mesma forma, a leitora Fátima toma da lógica positivista na sua interlocução de oposição, mantendo também uma perspectiva egocêntrica com estruturas de perspectiva de conexão recíproca e simetria de compensações na representação de justiça (Anexo I, p. 18).

\footnotetext{
"Ao sr. Eduardo Grigolo ('Painel do Leitor', 28/8) e todos os homens que são contra o aborto nos casos de estupro: que tal uma lei em que a vítima não tivesse o direito de abortar, mas em que o estuprador, ao cometer 0 ato, tivesse 0 pênis cortado?" FO-31/08/97
}

\section{DISCURSO 6}

Esta seqüência de cartas ocorre na mesma época do discurso 5 e alguns leitores dialogam com o ministro da saúde Carlos Albuquerque e o presidente do Supremo 
Tribunal Federal Celso de Mello. As cartas analisadas a seguir orientam-se frente à postura contrária do primeiro e favorável do segundo.

Os pronunciamentos foram bastante polêmicos na ocasião e com destaque especial ao do ministro Celso de Mello pois, pela primeira vez, um ministro rompeu com a tradição do sagrado do Supremo Tribunal de Justiça. Na ocasião tanto a FO como o OE escreveram editorial sobre o assunto e elaboraram reportagens e entrevistas para tratar do tema: FO23/08/97, FO-28/08/97, FO-30/08/97, FO-33/09/97, FO-21/09/97, FO-05/10/97 e OE $22 / 08 / 97$, OE $-24 / 08 / 97$ OE $-25 / 08 / 97^{46}$

As duas primeiras cartas são contrárias ao aborto mas argumentam de forma diversificada. A primeira faz uma leitura egocêntrica de um padrão de comportamento individual para a questão do direito à vida enquanto a segunda, na relação eu-tu, posicionase também como uma observadora adotando a perspectiva da terceira pessoa que olha para si própria. (Anexo I, p. 14-15)

\begin{abstract}
"Por continuar acreditando que o feto não é apêndice no corpo da mãe e toda pessoa, desde a sua concepção, tem direito à vida, parabenizo o ministro Carlos Albuquerque por sua posição contrária ao projeto que prevê a obrigatoriedade de atendimento pelo SUS dos casos de aborto previstos no Código Penal." FO24/08/97
\end{abstract}

\begin{abstract}
"Causou-me profunda indignação a frase do ministro da Saúde, Carlos Albuquerque, a respeito do projeto de lei que regulamenta - aborto em casos de estupro ou de perigo de vida para a gestante: 'Sou contra o aborto devido a minha formação religiosa, moral, ética e profissional'. Como aceitar que uma mulher seja obrigada a dar à luz, criar e amar um filho que ela não escolheu ter? E se fosse com uma filha do ministro?" FO24/08/97
\end{abstract}

As três próximas demonstram suas opiniões sobre o ministro sendo que a terceira atinge o nivel convencional ao trabalhar na interação de tipo de ação guiada por norma, cobrando da autoridade a vontade coletiva - olhar para a realidade brasileira, em uma perspectiva do falante do mundo. (Anexo I, p. 16-19)

\begin{abstract}
"Gostariamos de parabenizar a Folha pela excelente cobertura que está fazendo sobre a implantação dos serviços de saúde gratuitos para os casos de aborto previstos em lei e a desastrosa declaração do ministro da Saúde, Carlos Albuquerque." FO$25 / 08 / 97$
\end{abstract}

\footnotetext{
${ }^{46}$ esta é uma das situações que podemos observar a presença maior do jornal FO no tratamento do assunto. Editorial de 23/08/97 lamenta a posição do ministro da saúde.
} 
"Inacreditáveis as declarações do ministro da Saúde, Carlos Albuquerque, e da Igreja Católica em relação ao projeto de regulamentação do aborto legal, que já existe há 57 anos." FO28/08/97

"Causou-me espanto a atitude do sr. ministro da Saúde de propor veto ao projeto que libera o aborto na rede pública em caso de estupro e risco de vida. Será que mais uma vez a hipocrisia de nossos políticos vai passar por cima de uma realidade brasileira?" FO-05/09/97

Os leitores do Estado de São Paulo para a mesma ocasião apresentaram pontos de vista com linguagens mais diversificadas (Anexo II, p. 8-12). Partem desde falas egocêntricas do estádio 1 e 2 do nível pré-convencional de relação eu-tu até argumentações com sistemas de perspectivas de nível convencional e pós-convencional. Faço destaque para as falas da quarta e quinta carta da sequêencia $O E-28 / 08 / 97$. A primeira olha para o Estado em uma referência egocêntrica acumulando no discurso uma cooperação governada por interesses ao argumentar sobre a separação do Estado e Igreja e a segunda trabalha com reciprocidade de ações respondendo no mesmo contexto que o ministro - aplicar a regra de ouro.

"Não posso conter o entusiasmo em face da coragem de nosso ministro da Saúde, Carlos Albuquerque. Finalmente, temos no Ministério alguém preocupado com a vida, e não em aparecer e agradar movimentos de pressão." OE-27/08/97

"Traz-nos alivio, alegria e esperança a bravura de nosso ministro da Saúde ao assumir sua posição contrária ao aborto. Ver um homem público falar de valores morais, éticos e religiosos resgata nossa esperança e patriotismo. Parabéns, sr. ministro. É de homens como o senhor que se faz uma verdadeira nação cristã." OE-27/08/97

"Só gostaria de saber se o ministro da Saúde e outros homens que atacam esta proposta de lei de forma tão acirrada criariam um filho, ou um neto, bastardo com o mesmo amor, como se fosse o próprio filho? Ou se eles na surdina cometeriam fraticídio?" OE-27/08/97

"O nosso ministro da Saúde vem sendo injustamente atacado por ativistas que não medem palavras na tentativa de menosprezar o conteúdo moral e ético de seu posicionamento contrário ao projeto que pretende regulamentar o aborto legal. Como se fossem sábios inatacáveis, não se pejam de afirmar que o ministro "ignora" aspectos de sua pasta, mas demonstram total indigência de saber quando, na tentativa de minimizar e 
reduzir o peso das declarações, reafirmam a separação da Igreja e do Estado, como se moral e ética fossem exclusividade da Igreja ou da religião. Se Estado laico é sinônimo de Estado sem compromissos morais e éticos, então é preciso rever a Constituição, pois acredito que até mesmo os parlamentares mais afoitos, se raciocinarem um pouquinho, concluirão que basta ser humano para aspirar o bem e a felicidade, tendo em conseqüência conviç̧ões morais e éticas, independentemente de credo religioso." OE-28/08/97

"Por suas declarações intempestivas e para livrar-se da suspeita de cinismo, o sr. ministro da Saúde, homem honrado, deve demitir-se do cargo caso o presidente venha a sancionar lei que for aprovada pelo Congresso sobre a regulamentação do aborto legal na rede pública, para mulheres sem recursos para pagar uma clínica particular." OE-28/08/97

"Gostaria de manifestar nosso apoio ao sr. ministro da Saúde, dr. Carlos César Albuquerque, contrário ao aborto, pois achamos que, independente das circunstâncias, o aborto é assassinato de um inocente." OE-29/08/97

Ainda no conjunto de cartas deste bloco destacarei, a seguir, para cada uma delas seus traços pessoais:

Usa da lógica do se...então usando do discurso do ministro para buscar uma reflexão com perspectiva do estádio 3 da regra do ouro: se é bom para eu é bom tu (para todos).

\begin{abstract}
"Então fica combinado assim, segundo nosso ministro da Saúde: mulher vitima de estupro que venha resultar em gravidez não poderá se submeter ao aborto - afinal ele é a favor da vida! Mas é permitido que crianças e adultos morram de sarampo, lepra, tuberculose, meningite e muitas outras doenças já erradicadas em outros países. Essa hipocrisia "dos pela vida" me causa náuseas!" OE-27/08/97
\end{abstract}

Faz diferenciação do mundo interno e externo ao olhar a realidade, acumulando a perspectiva de um observador e coloca em dúvida o sistema de normas duvidando de uma simetria de compensações

"Gostaria de dar os parabéns ao ministro da Saúde por ter tido a coragem de posicionar a favor da vida e contra o aborto. Acreditar que a legalização vá diminuir o número de abortos clandestinos demonstra um enorme desconhecimento da realidade social, na qual muitas jovens procuram justamente a clandestinidade do aborto para fugir do reconhecimento de sua situação por sua família. Ou seja, mesmo com a legalização, abortos clandestinos continuarão a ser praticados." OE-27/08/97 
Este último leitor escreveu também para FO em 05/08/97 usando o mesmo início de carta. Nesta seu argumento se completa e ele contesta a posição egocêntrica do ministro remetendo à realidade do mundo externo - nível convencional

\begin{abstract}
"Causou-me espanto a atitude do sr. ministro da Saúde em propor veto ao projeto aprovado na Comissão que libera o aborto na rede pública em caso de estupro e risco de vida. Será que mais uma vez a hipocrisia de nossos políticos vai passar por cima de uma realidade brasileira? Que a Igreja queira impedir, em parte aceito, já que quando seminarista vivenciei seus princípios retrógrados. Mas o sr. ministro alegar ser contra o projeto por princípios religiosos é inaceitável. o ministro não deve ter trabalhado em pronto-socorro atendendo mulheres vítimas de estupro ou com septicemia pós-aborto, que, desesperadas, procuram curandeiras, pais-de-santo." OE-27/08/97
\end{abstract}

Discute a conformidade de sistema de normas na perspectiva de comportamento socialmente generalizado do nível convencional cobrando a legitimidade da autoridade

\begin{abstract}
"Nada mudou por aqui desde a chegada de Cabral há 497 anos. É só conferir na primeira página do Estado de 22/8. FMI sugere cuidado com déficit externo. Continuamos colônia e muito mal administrada. Sem poder. Sem comentários, a foto diz tudo. Ministro vai pedir veto a aborto a $\mathrm{FH}$. Nas entrelinhas lê-se que irritado o presidente da CNBB é contra o assunto. A Santa Madre Igreja continua agindo como nos tempos do Tratado das Tordesilhas. A nossa independência foi a melhor anedota de português que já escutei até hoje." OE-27/08/97
\end{abstract}

E por último um leitor reclama do ministro o seu papel convencional e pósconvencional em fazer a conexão do interagir guiado por normas com o interagir na perspectiva de um observador participante fazendo-as a partir das perspectivas de sipróprio com as do mundo.

"Ou se revoga o artigo 128 do Decreto-lei 2.848 , de $7 / 12 / 40$ (Código Penal), ou o ministro da Saúde deve exigir, com simples portaria, que a rede pública de saúde cumpra a lei, executando o aborto necessário e o aborto no caso de gravidez resultante de estupro. É bizantina a discussão em torno da desnecessária regulamentação. Ademais, o ministro deverá sempre lembrar que "a saúde é direito de todos e dever do Estado", conforme o artigo 196 da Constituição." OE-29/08/98

O comportamento dos leitores com respeito ao ministro Celso de Mello foi distinto ao grupo que se dirige ao de Carlos Albuquerque, pois somando-se os dois jornais somente foram identificadas quatro cartas sendo três de representantes do judiciário: do Instituto 
Brasileiro de Advocacia Pública FO- 05/10/97 e procuradores do Estado, Conselho Executivo da Associação Juízes para a Democracia que envia a mesma carta para os dois jornais FO- 08/09/97e OE- 9/09/1997 e uma da associação Católicas pelo Direito de Decidir FO- 30/08/97

\section{DISCURSO 7}

A reunião de cartas deste discurso 7 é gerada a partir da declaração da primeira dama Ruth Cardoso na ocasião da visita do papa João Paulo II ao Brasil:

"a relação entre o Congresso Nacional e o papa é zero."

Esta refere-se à não intervenção da Igreja nos negócios do Estado. Sua fala está colocada no estádio 5 , pós-convencional. Diz respeito ao contrato social, que as pessoas adotam uma variedade de opiniões e valores relativos ao seu grupo e que devem obedecer as leis do contrato, as leis do Estado.

Uma carta foi desfavorável a este pronunciamento, FO- 18/10/97. Afora comentar o pensamento da primeira dama, conversa com uma leitora representante da Comissão de Cidadania e Reprodução, FO- 03/10/97. Esta carta argúi sobre a parcialidade da declaração feita comentando que as partes contrárias devem ser ouvidas de modo igualitário. $\mathrm{O}$ que se percebe é uma argumentação que transita da idéia do direito eqüitativo do estádio 1, préconvencional (a razão para fazer o que é direito é servir às necessidades e interesses próprios num mundo em que é preciso reconhecer as outras pessoas) para o estádio 4 , convencional, (e se todos fizéssemos o mesmo?’). (Anexo I, p. 25 e 32)

"Estranhamos a manifestação da leitora Margareth Arilha ('Painel do Leitor', 3/10) _sobre a posição de Ruth Cardoso em relação ao papa e ao aborto legal_, porque é facciosa. A população em geral defende a pluralidade de opiniões. Idéias contrárias devem ser recebidas e meditadas com o mesmo respeito." FO- 18/10/97

"A Comissão de Cidadania e Reprodução (CCR) vem a público dar total apoio à posição externada por Ruth Cardoso no sentido de preservar o direito à manifestação da pluralidade de opiniões no campo dos direitos sexuais e reprodutivos, repudiando qualquer tipo de pressão que a Igreja Católica possa vir a exercer sobre os poderes maiores do Estado brasileiro Executivo, Legislativo e Judiciário. "Margareth Arilha, secretária-executiva da Comissão de Cidadania e Reprodução (CCR), seguem-se mais nove assinaturas (São Paulo, SP) FO03/10/97 
A carta seguinte elogia a Folha de São Paulo na forma de cobertura dada ressaltando o aspecto variedade de opiniões do estádio 5 (regras relativas ao grupo devem ser apoiadas no interesse da imparcialidade). (Anexo I, p. 25)

\footnotetext{
"Nota dez para a Folha. Ao dar na primeira página a chegada de Sua Santidade, o papa, e seu ataque ao aborto, também destaca a posição pró direito ao aborto da primeira-dama, Ruth Cardoso. É dessa maneira que consolidaremos a democracia brasileira: ouvindo sempre os dois lados!" FO- 05/10/97
}

O leitor Idoeta concorda com Ruth Cardoso em sua posição de estádio 6, pósconvencional e ressalta a importância do espaço da Igreja e o direito à vida com argumento do estádio 5 semelhante à carta anterior (Anexo I, p. 26)

\begin{abstract}
"Graças a alguém, hoje vivemos em uma república laica. A sra. Ruth Cardoso está certa quando invoca a separação entre o Estado e as religiões _a majoritária inclusive_ nas deliberações dos três poderes sobre a dura questão do aborto. $O$ atual debate sobre a defesa da vida também oferece à hierarquia católica nova oportunidade para que enfim manifeste, sem ambiguidade, sua oposição incondicional à pena de morte." FO- 06/10/97
\end{abstract}

\title{
DISCURSO 8
}

Em dezembro de 1997 o PL 20/91 foi para votação no Congresso Nacional. Neste período uma nova sequêencia de cartas voltam a aparecer no espaço de leitores dos jornais FO e OE. A análise que se segue restringe-se a um grupo de juristas em discussão sobre o assunto no jornal Folha de São Paulo. Volta em cena o deputado Hélio Bicudo com o professor Ives Gandra da Silva Martins (Anexo I, p. 24), argumentando em oposição ao aborto legal e contracenam com argumentos favoráveis Marcelo Pereira, doutor em Direito Estado/USP (Anexo I, p. 23); Flavia Piovesan, procuradora do Estado e a professora Silvia Pimentel. (Anexo I, p. 34-35)

A conversação inicia-se em setembro com um artigo do deputado Hélio Bicudo FO12/09/97 sob o título "O aborto e a Constituição: As disposições do projeto não protegem a vítima de estupro quando pretendem possibilitar a interrupção de gravidez". Nos dias subseqüentes duas cartas trazem manifestações sobre o mesmo. A carta assinada pelo Marcelo Pereira faz uma denúncia ao conteúdo falacioso do artigo colocando em dúvida a pretensão de validez quanto a correção e sinceridade. 
"Embaralha conceitos e tenta justificar uma convicção pessoal
em termos legais, dando uma interpretação falaciosa ao
dispositivo constitucional mencionado." FO- 13/09/97

Em FO-17/09/97, o jurista Yves Gandra em argumentação positivista, cumprimenta o deputado e concorda com a sua interpretação de que a Constituição de 1988 colocou o direito à vida como direito fundamental lembrando que já havia discorrido sobre o assunto em seu livro com Celso Bastos sobre comentários a Lei Maior e conclui

"O que era 'legal' no passado é 'inconstitucional' no presente. Qualquer forma de aborto atinge a vida, direito plenamente garantido na Constituição, sendo, pois, maculadora da ordem jurídica." FO-17/09/97

As duas cartas são construídas na relação eu-tu para uma perspectiva individualista concreta a qual trabalha para o primeiro a relação de interesses individuais conflitantes e concordes para o segundo - nível pré-convencional.

A discussão é retomada em novembro, FO-27/11/97, quando Piovesan e Pimentel publicam um novo artigo sobre o tema, "O direito constitucional ao aborto legal", fazendo referência às posições contrárias de Bicudo e Gandra. Ao contrário do artigo de Bicudo, a argumentação das autoras afasta-se de um mero discurso positivado para uma outra dimensão de experiência moral que trabalha a hermenêutica não exclusivamente em critérios abstratos e gerais positivados na Constituição Federal e Código Penal mas buscam o contexto e o momento da discussão também como força de argumento.

Isto leva à redação de uma carta de Yves Gandra replicando as duas autoras a qual transcrevo em sua integridade para análise

"Em artigo publicado sob o título 'o direito constitucional ao aborto legal', à pág. 1-3 (Opinião), de ontem, as professoras Flávia Piovesan e Silvia Pimentel contestam posição minha e de Hélio Bicudo, alegando que, na Constituição Federal, o direito à vida, 'ainda que fundamental, não é, contudo, absoluto', sobre reproduzir a Lei Suprema de 1988 o principio de direito anterior. Argumentam que os direitos à liberdade e à propriedade podem ser conjugados com a tolerância e a justiça social.

Não me parecem, todavia, corretas as afirmações. Dos cinco direitos fundamentais, quatro deles (igualdade, segurança, liberdade e propriedade) têm, na própria Constituição, elementos redutores de seu absolutismo, como bem acentuam as juristas, ao exemplificarem com as limitações à liberdade $e$ à propriedade. $O$ direito à vida, não. Em nenhum momento a Constituição abre nenhum campo para sua redução, motivo pelo qual, dos cinco direitos fundamentais elencados no 'caput' do 
artigo, quatro deles são relativos e um absoluto. Por outro lado, a Constituição Federal atual assegura o 'próprio direito à vida', enquanto a anterior apenas assegurava 'direitos concernentes à vida', sendo pois, na dicção pretérita, relativo o direito à vida e, na atual, absoluto.

É, de resto, a interpretação que Celso Bastos e eu ofertamos, ao comentarmos, em 15 volumes, pela Saraiva, a Constituição do Brasil.

Ademais da exegese constitucional, por convicção própria, sou contra todos os atentados à vida, não aceitando soluções jurídicas adotadas por outros países, como a pena de morte, a eutanásia e o aborto." FO- 28/11/97

Denota-se mais uma vez uma argumentação positivista. Sua fala transita entre o nível pré-convencional/convencional misturando condições do ponto de vista egocêntrico que não considera os interesses dos outros. Ele adota o ponto de vista do sistema quando reforça a sua posição com respeito à Constituição Federal. A intenção da carta é única e exclusivamente confutar as duas juristas.

Nas vésperas da eleição a Folha de São Paulo novamente publica artigo de Hélio Bicudo onde ele mantém sua posição com respeito ao aborto legal. Bicudo volta a argumentar positivamente sobre a Constituição e o direito à vida sem fazer referência às duas juristas mas, abrindo uma brecha nova na sua fala que o posiciona em novo nível de ação comunicativa. Ele sai da posição egocêntrica de interação governada por autoridade (poder hermenêutico jurídico) do nível pré-convencional para uma posição de observador participante do nível convencional contudo ainda somente justificado no direito positivado. (Anexo I, p. 39)

"O que se pode fazer, compreendendo as pressões psicológicas e
sociais a que a mulher possa estar sujeita, uma vez cometido o
delito, é não aplicar à gestante a pena prevista na figura penal
do "aborto criminoso", como a lei penal também permite." FO-
$05 / 12 / 97$

Em decorrência deste comportamento, uma nova carta de Piovesan e Pimentel é publicada em FO-11/12/97, onde elas discorrem sobre o comportamento contraditório de Bicudo (Anexo I, p. 39)

"O artigo 'Aborto legal, ledo engano', de Hélio Bicudo, na Folha de 5/12, revela explícita contradição quando afirma que a Constituição de 1988 não recepciona o aborto legal previsto pelo Código Penal. Ao mesmo tempo em que faz tal afirmação, o autor apresenta argumentos jurídicos pela admissão do aborto 
legal. Quanto ao aborto em caso de risco de morte da gestante, alude ao instituto do estado de necessidade. Quanto ao aborto em caso de estupro, admite que 0 que se pode fazer, 'compreendendo as pressões psicológicas e sociais a que a mulher possa estar sujeita (...), é não aplicar à gestante a pena prevista, como a lei penal também permite'." FO-11/12/97

A forma de discurso das autoras não difere no conteúdo e no tipo de ação que já permeava o artigo anterior. Desenvolve-se nivel pós-convencional motivado na relação autonomia e heteronomia com orientação em função da fundamentação de normas. Isto pode ser denotado no encaminhamento dado à questão na seqüência da carta

"A partir desse raciocínio, comprova a existência de um complexo e tenso conflito valorativo, que implica a relativização do direito à vida: na primeira hipótese, para salvaguardar a vida da gestante, e na segunda, para proteger a dignidade da mulher vítima do estupro. Vislumbra-se, assim, a adoção do pensamento contemporâneo que justifica a relativização de direitos fundamentais à luz do paradigma da dignidade humana _interpretação que é absolutamente consonante com a Constituição de 1988 e que é reiterada pelas autoras que esta subscrevem. Daí a importância da aprovação do PL20/91, que regulamenta o atendimento pela rede pública de saúde dos casos de aborto previstos em lei, o que beneficiará, principalmente, as mulheres pobres." FO-11/12/97

Contudo, uma última carta de Bicudo às juristas, FO-13/12/97, não volta a evidenciar passagem de um nível para o outro. Novamente e o deputado volta a argumentar limitando-se a um discurso no direito positivado, nivel pré-convencional.

"Gostaria de lembrar às ilustres subscritoras da carta inscrita no 'Painel do Leitor' de 11/12, sob o título 'Aborto legal', que seria interessante uma leitura da norma constante do artigo $5^{\circ}$, parágrafo $2^{\circ}$, da Constituição Federal: 'Os direitos e garantias expressos nesta Constituição não excluem outros decorrentes do regime e dos princípios por ela adotados, ou dos tratados internacionais em que a República Federativa do Brasil seja parte' e, de seguida, do que está escrito no artigo $4^{\circ}$, inciso I, da Convenção Americana de Direitos Humanos (Pacto de São José da Costa Rica), ratificado pelo Brasil: 'Toda pessoa tem o direito de que se respeite a vida. Esse direito deve ser protegido pela lei e, em geral, desde o momento da concepção'. Encartado o direito à vida, desde a concepção, como cláusula pétrea, não há, em definitivo, que falar em 'aborto legal'." 


\section{DISCURSO 9}

O PL 20/91 foi retirado de pauta de votação em 10/12/1997 juntamente com o PL 1151/95 da deputada Marta Suplicy que tratava da união civil entre pessoas do mesmo sexo, por proposição do deputado federal Salvador Zimbaldi (PSDB-SP). Até esta data um outro bloco de discussão situa-se como última troca de cartas entre leitores para o ano de 1997. Duas pessoas concentram as discussões aqui desenvolvidas: o padre Luiz Carlos Lodi da Cruz já visto no discurso 4 e a leitora Bartira Martins. O colóquio dá início porque Lodi levou duas crianças, uma filha e um neto de mulheres estupradas, ao plenário da Câmara no dia 25/11/97, durante audiência pública sobre o PL 20/91. (Anexo I, p. 35-37)

A primeira carta é de Bartira, FO-04/12/97 (Anexo I, p. 35), numa relação eu-tu pré-convencional. Ela trabalha com a relação recíproca de perspectivas de ação as quais são reconhecidas como potencialmente diferentes, Bartira responde à ação de Lodi ${ }^{47}$ em usar de qualquer estratégia para obter o que deseja na mesma linguagem e comportamento ao comparar vermes e vírus ao discurso de direito à vida utilizado por Lodi.

\section{"Senhor padre Luiz Carlos Lodi da Cruz, meta-se com o seu terço e a sua batina. O corpo da mulher só a ela pertence." Sugestãozinha: não mate os vermes ou vírus que seu corpo possa vir a abrigar, pois são formas de vida."}

Esta reação de Bartira não é comum a todas as pessoas. No mesmo espaço e dia do leitor, outro modo de opção expressiva se apresenta como resposta ao comportamento de Lodi. A leitora Glória L. Xavier Pedro concorda que as crianças foram expostas à situação vexatória e ela aplica a regra de ouro do estádio 3 mas, ainda em dúvida indaga se neste caso o fim não justifica o meio.

\footnotetext{
"Concordo que as crianças foram expostas a uma situação vexatória, mas será que nesse caso o fim não justificou os meios? Com certeza absoluta, justificou."
}

Neste momento, os leitores que escrevem para o painel do leitor enviam cartas para Lodi e para Bartira, FO- 05/12/97 e FO- 08/12/97. Duas leitoras, adversárias ao aborto, mantendo diálogo eu-tu do estádio 1 , no qual a pessoa não relaciona dois pontos de vista, compreendem a carta de Bartira de uma outra maneira

"É inconcebivel, malcriada, agressiva e inoportuna a manifestação da leitora Bartira Martins, no 'Painel do Leitor' de $3 / 12$, contra o padre Luiz Carlos Lodi da Cruz, que defende a

\footnotetext{
${ }^{47}$ ver entrevista FO-01/12/97 em anexo.
} 
vida e critica o aborto. Comparar vermes e vírus ao ser humano foi a prova do limite de sua inteligência. Mesmo para pessoas assim não se deseja a morte por aborto."

"É horripilante saber que existem psicopatas soltos com direito a extravasar suas opiniões, como Bartira Martins no 'Painel do Leitor' de 4/12. Equiparar um ser humano a vermes e vírus é coisa de doente mental. $O$ corpo da mulher não the pertence nem pelas leis humanas _quanto mais o de um filho, que não é produto exclusivamente da mulher. Que d. Bartira aprenda a rezar o terço; Deus vai perdoá-la e curá-la dessa doença terrivel."

Estas são intercaladas com um leitor, FO- 08/12/97, que conversa com Lodi em linguagem de estádio 3, convencional que, na perspectiva do indivíduo em relação aos outros, aplica a regra de ouro e aduz:

"Acho que só Freud explica o desejo do padre Luiz Carlos Lodi da Cruz de ser preso. Se ele não respeita a dignidade de dois menores, não deve ter a menor consideração pela sua."

Ainda neste mesmo ano, ocorre uma reflexão elogiosa nível convencional, estádio 3 do agir em papéis, de uma leitora com o articulista da FO Marcelo Coelho, FO- 03/12/97, com respeito ao artigo "Discurso antiaborto é atentado contra 'vida humana",

"Nota dez para o artigo escrito por Marcelo Coelho em $3 / 12$,
'Discurso antiaborto contra a vida humana'. Podemos chegar à
conclusão que a igreja realmente não se importa com o amor e
que o sexo existe somente para a reprodução, não importa se a
mulher foi vítima de estupro." FO- $15 / 12 / 97$

Com respeito a este assunto o jornal OE apresenta somente uma carta tratando do assunto. Este jornal quando não publica todas as cartas enviadas inclui ao final da seção um agradecimento às cartas não publicadas e cartas enviadas por Lodi não foram publicadas, pois seu nome consta por diversas vezes nesta lista. A única correspondência referida sobre o assunto é de uma leitora que elogia ironicamente a atitude de Lodi em levar as crianças à tribuna da Câmara dos Deputados. Ela mantém fala em nível convencional com a perspectiva de um observador do estádio 3 , justificando o papel da mulher e da mãe justificado no código penal em estádio 4 .

"(...) As mães estupradas desejaram ter seus filhos. A mulher que for estuprada, ficar grávida e desejar ter seu filho pode têlo. O legislador de 1940 foi muito sensivel e humano ao perceber e amparar a dor da mulher que, além de estuprada, ficou grávida e não quer continuar essa situação. Não tem nada que 
ver com gravidez indesejada, planejamento familiar, assassinato ou ser contra a vida. É a ocorrência de um crime e, novamente, a facilidade de defender os direitos humanos de todos, menos o da vítima. O padre precisa levar à tribuna pelo menos duas mulheres (há milhões) desesperadas que ficaram grávidas de criminosos estupradores e tiveram ou têm dificuldade de abortar (as pobres, é claro)." OE- 1/12/1997

\title{
DISCURSO 10
}

O conjunto de cartas deste bloco referem-se ao ano de 1998. O projeto está em recurso e a tensão latente. No final deste ano, conforme resolução 258 do Ministério da Saúde, foi assinada a norma técnica intitulada "Prevenção e tratamento dos agravos resultantes da violência sexual contra mulheres e adolescentes", pelo ministro José Serra. Apresento um perfil das cartas enviadas despolarizadamente durante o ano e assim também será feito para os anos de 1999, 2000 e $2001 .^{48}$

As três primeiras apresentam conversa em nível convencional na perspectiva de um observador, variando a competição de argumentos: direito e tutela da vida, conhecimento médico e pareceres para aborto em mal formação, direito humanos e vida

\begin{abstract}
"Após ler e refletir sobre a entrevista concedida pelo professor dr. Ney Moura Teles, na pág. 1-4 (Brasil), de 23/2, gostaria de recordar ao professor que o grande escopo do direito é tutelar a vida. Portanto legalizar o aborto nos casos em que o feto tenha 'deformações físicas' e permitir a 'ortotanásia' é ferir o grande escopo do Direito. Em nossos tempos contemporâneos, a vida tem tido pouco apreço, fruto de uma sociedade materialista e hedonista. Se podemos apagar uma simples luz com um toque no controle remoto, por que não abolirmos quaisquer formas de sofrimento? Sofrimentos esses que na verdade são nossos, não do feto e do doente. Que o direito diga não a tudo isso e nos tutele de verdade." FO- 03/03/98
\end{abstract}

"Quando a Folha defende no editorial "O aborto e a lei", de 24/2, que, "no caso da interrupção da gestação de crianças sem chances de sobrevida, pode-se dizer que o debate está amadurecido' pois, "com o respaldo de parecer abalizado de médicos, juízes têm concedido direito ao aborto', está simplesmente agindo ou com ingenuidade ou com má-fé. Tais pareceres de médicos estão longe de refletir a verdade sobre o que é a vida e não são os baluartes da última palavra. $O$ assunto continua imaturo. Parece-nos que a Folha está defendendo o

\footnotetext{
${ }^{48}$ A carta FO- 25/07/98 'Marta deixa polêmica fora de sua campanha", trata de uma denúncia à não adequada informação sobre a campanha de Marta Suplicy e não dos aspectos desta discussão.
} 
hitlerismo, a raça pura, sem anomalias, com seres perfeitos, que devem predominar sobre os imperfeitos, que nada são e portanto devem ser eliminados." FO- 09/03/98

"Em relação às notícias de reforma do Código Penal, gostaria de lembrar que direitos humanos e vida não combinam com aborto, eutanásia, estupro. Pobre do país que não protege os que não têm voz, mas possuem direitos naturais." FO-26/03/98

As duas cartas seguintes argumentam em nível pré-convencional com padrão de comportamento particular em interação governada por autoridade, pois ambas orientam-se em função de recompensa e castigo: aborto é pecado e castigado / aborto é crime mesmo não punido.

\begin{abstract}
"Na edição de 18/4, reportagem publicada em Mundo sobre o Santo Sudário contém um engano. Por intermédio do padre ou não, a misericórdia divina perdoa todos os pecados, desde que haja arrependimento e propósito de não mais cometê-los. Não há pecado imperdoável nem circunstâncias especiais, como a visita ao Santo Sudário a Turim, para o seu perdão. 0 aborto também está entre eles." FO-23/04/98
\end{abstract}

\begin{abstract}
"Seria deselegante se a Folha, após abrir espaço para uma abortista, não o abrisse para um artigo de quem está a favor da vida e da defesa do mais desarmado dos seres: o bebê no ventre materno ("O blefe dos abortistas", Luiz Carlos Lodi da Cruz, Opinião, pág. 1-3, 24/4). O aborto provocado será sempre criminoso, ainda que não punivel." FO-27/04/98
\end{abstract}

Finalmente as duas últimas refletem um discurso jurídico em nível convencional. Tratam os conflitos entre oponente e proponente em tomadas de posições individuais em conformidade com os sistemas e normas. A primeira cobra da positividade do direito não respeitado pelo promotor de justiça ao interpor recurso quanto à autorização de aborto de uma criança estuprada e, a segunda, peca por correção e sinceridade ao tratar em sua competição argumentativa sobre uma fala não argumentada pela representante da Comissão da Mulher advogada da OAB-SP.

"A Comissão da Mulher Advogada da Seccional Paulista da OAB,
reafirmando o compromisso com o respeito à dignidade da
pessoa humana, como valor ético essencial, exterioriza o
protesto em relação ao tratamento que a Igreja Católica vem
dispensando à criança C.B.S. e sua família, legalmente
respaldada para a realização do aborto de gravidez decorrente
de estupro, na cidade de Israelândia, Goiás. É descabida a
atitude e ilegal o recurso do promotor de Justiça Reuder Motta, 
pois sua manifestação é mais uma agressão à menina." FO$26 / 09 / 98$

\begin{abstract}
"Como advogado e presidente da Associação Nacional dos Advogados Contra o Aborto, venho protestar contra o pronunciamento da Comissão da Mulher Advogada da Seccional Paulista da OAB ('Painel do Leitor', 26/9), o qual confunde respeito à dignidade da pessoa humana como valor ético essencial com o direito de matar seres humanos ainda não nascidos, pelo fato de terem sido, tanto quanto a mulher violentada, vítimas de algum degenerado." FO- 29/09/98
\end{abstract}

\title{
DISCURSO 11
}

$\mathrm{O}$ assunto é retomado neste ano por conta do deputado Severino Cavalcanti (PPBPE) ao apresentar proposição junto à Comissão de Seguridade Social da Câmara dos Deputados contra a aplicação da norma do Ministério da Saúde, assinada no ano anterior, a qual autorizava os hospitais públicos a realizar abortos em mulheres estupradas que queriam interromper a gravidez. Em 31 de janeiro de 2003 a mesa diretora da Câmara dos Deputados arquivou o caso.

As duas primeiras cartas decorrem do editorial FO- 21/08/99 "Sectarismo antiabortista" e ambas de profissionais ligados à instituições relacionadas. $\mathrm{O}$ primeiro enquadra-se no discurso convencional com uma ação guiada por normas e portanto pela legitimidade da mesma. Thomaz Rafael Gollop, diretor do Instituto de Medicina Fetal de São Paulo, explica que

\footnotetext{
"Nenhum médico é favorável ao abortamento. É forçoso reconhecer entretanto que, em determinadas situações, ele é a única saída possível e deve ser contemplado com assistência médica exemplar. " FO- 27/08/99
}

A segunda fala, de Nubor Orlando Facure e Lourdes Gomes Facure, diretores do Instituto do Cérebro em Campinas, situa-se na perspectiva egocêntrica de cunho religioso contrário ao aborto e preocupado com o ser que está sendo gerado e o direito à vida.

"Os argumentos da Folha não levam em conta, como de costume, a maior vítima no caso, que é um ser vivo que está sendo gerado e, diga-se de passagem, completamente sem culpa. Ainda precisamos criar um 'Código de Direito da Criança' que está por nascer e aguardar comprovação pela ciência de que a vida física é uma expressão acanhada da vida espiritual que floresce em todos nós." FO- 27/08/99 
As próximas três cartas fazem parte de uma única conversa. Primeiro a representante do Conselho Estadual da Condição Feminina, Maria Aparecida de Laia faz uma colocação que é altercada por um leitor que escreve sistematicamente para os dois jornais investigados. A seguir uma leitora argumenta com este último

"Como é possível que, às vésperas do século 21 , ainda se
discuta um tema aprovado pelos parlamentares em 1940?
ministro da Saúde, ao regulamentar essa norma técnica, nada
mais quer do que fazer cumprir o dever do Estado." FO-
$15 / 09 / 99$

Três dias depois, o leitor Olival Oliveira dos Santos critica esta carta trazendo uma argumentação pré-convencional de ação governada por interesse e criando um conflito guiado por interesses
"A leitora Maria de Lara49 ('Painel do Leitor', 15/9) comete erro palmar ao julgar o modo de pensar de parlamentares da década de 40. Hoje em dia, o problema continua o mesmo: discernir sobre as circunstâncias do estupro, ou seja, se aconteceu realmente ou se houve uma relação sexual consentida. Mesmo para médicos esse é um problema de solução difícil." FO- $17 / 09 / 99$

Em decorrência deste fato, três dias depois, o painel do leitor traz uma nova carta, FO- 20/09/99, tratando do assunto colocado por Olival, também iniciada em argumento pré-convencional de perspectivas de ação recíprocas terminando em simetria de papéis.

\begin{abstract}
"(...) Segundo o leitor, o problema do aborto legal é 'discernir se houve estupro ou relação sexual consentida'. Esse homem parte do princípio de que se deve duvidar sempre da palavra da mulher. Coloca a 'vida' do produto da concepção em patamar de dignidade maior do que o da vida, da liberdade e da integridade física e psicológica da mulher. Esse homem propaga o velho pensamento machista: só se houver certeza de que a mulher não manteve relações sexuais 'porque quis' é que o feto poderia ser removido. Assim, segundo esse homem, seria preferivel, na dúvida, obrigar-se uma mulher a dar à luz ao filho de um estuprador a sacrificar o feto. Ou seja, na dúvida, a favor do feto, jamais a favor da mulher. Esta não tem direitos humanos, pois não é vista como pessoa, mas sim como uma barriga, uma escrava da reprodução, enfim, uma subcidadã. O machismo é um preconceito tão ignominioso quanto o racismo. A discriminação de sexo, e não o aborto, deveria ser crime." FO20/09/99
\end{abstract}

\footnotetext{
${ }^{49}$ o leitor Olival grafou de forma errada o nome de Maria Aparecida de Laia.
} 
A última carta, aplica uma ação pré-convencional como já analisado anteriormente, estádio 2, perspectiva egocêntrica, na qual observa-se o conceito de autoridade em arbítrio sancionado externamente pela figura de Deus.

\begin{abstract}
"A respeito da reportagem sobre aborto (Cotidiano, 19/12), creio que, excetuando o risco de morte para a mãe, que praticamente já não existe devido aos avanços da medicina, o ato de aniquilar um ser humano no ventre materno constitui covarde assassinato doloso, com consequências horriveis para os participantes diretos e indiretos. Se não são punidos pelas leis dos homens, que é falha, o serão pela lei de Deus, que é infalível." FO$24 / 12 / 1999$
\end{abstract}

\title{
DISCURSO 12
}

No ano de 2000 o assunto aborto aparece somente no segundo semestre acompanhando as eleições municipais. As cartas FO- 20/09/00, FO- 18/10/00, FO24/10/00 simplesmente mencionam o termo no contexto das eleições à prefeitura de São Paulo (Marta Suplicy e Paulo Maluf). Nesta ocasião a Folha de São Paulo escreve um editorial em 01/10/00 sob o título "Química do aborto" e nos dias subsequentes alguns leitores voltam a discutir a questão. Os dois leitores contra o aborto reconhecem que ele é contra a vida e à natureza e que as pessoas que o praticam devem ser punidas estádio 2 , pré-convencional mas, diferentemente de outros leitores já avaliados, ambos se posicionam em um estádio 4 convencional adotando o ponto de vista do sistema e reconhecem na posição de um observador a necessidade de se acabar com as causas do aborto dentro da sociedade. (Anexo I, p. 63-64)

"É de surpreender a argumentação do editorial 'Química do Aborto' (Opinião, 1\%/10). Quer defender o aborto? Defenda. Quer considerar desprezível a vida do feto em favor da vida da mulher que aborta? Faça-o. Mas com decência e coerência. Pensemos com a cabeça: os fetos são vitimas da decisão dos que os abortam. As mulheres que abortam, quando sofrem as consequências, são vítimas da própria decisão de abortar. Elas correm o risco de uma espécie de opção provável pelo suicídio. Os fetos são puramente assassinados e de surpresa, sem qualquer ato culposo da parte deles. São as mais inocentes das vítimas. Não se quer, de modo algum, menosprezar a mulher que aborta. Não se menospreza o assassino que assassina, seja qual for a sua justificação. Apenas se afirma que o faz por decisão própria. No caso do aborto, a assassina do feto corre o risco de estar se suicidando. No caso do assassino, ele corre o risco de ser punido pela Justiça. O que é preciso é que a 
sociedade acabe com as causas do aborto e com as causas de tantos outros males, e não que, por não conseguir fazê-lo, legalize tudo o que for contra a natureza humana." FO- 06/10/00

"Excelente o editorial 'Química do aborto' (Opinião, 1\%/10), mas para provar que o colunista não sofreu as barbáries do aborto e, portanto, tem toda a liberdade para defender suas idéias que resultam em agressões contra a natureza humana. Aquele resultado 'positivo' do teste de gravidez fornecido pelo laboratório quer dizer alguma coisa? Chega de paliativos. Não se pode corrigir um mal com outro ainda maior. Enquanto estivermos colocando o homem como centro de tudo, não chegaremos a lugar nenhum, a não ser ao apodrecimento da sociedade, onde tudo é permitido. $O$ que se tem feito de concreto pelas nossas crianças e adolescentes que precocemente já são vítimas de todo esse processo? Apenas propagandas, filmes, novelas e programas apelativos para aguçar o seu instinto sexual e desvirtuar os verdadeiros valores morais, que resultarão na defesa de critérios ditos em favor da vida." FO$07 / 10 / 00$

Uma terceira leitora apresenta uma reflexão de estádio $3 / 4$ com perspectiva de coletivo quando se coloca entre o grupo de mulheres que reivindicam direitos e ao chamar a sociedade para a discussão do direito ao aborto passa para um comportamento socialmente generalizado da lealdade entre mulheres à legitimidade da situação em sistemas de normas

\begin{abstract}
"(...) Parabéns por saírem na frente na defesa desse direito de nós, mulheres. Espero que, a partir de agora, possamos contar com um interlocutor de peso na luta para ampliação do direito ao aborto. A sociedade não pode mais ignorar a terrivel situação com que se deparam centenas de milhares de mulheres quando optam por interromper uma gravidez indesejada $e$, na clandestinidade, pagam por essa insurreição até com a própria vida." FO- 07/10/00
\end{abstract}

\title{
DISCURSO 13
}

A conversa destas duas leitoras fazem a passagem do ano 2000/2001. Ambas fazem referência ao editorial "Aborto e crime", FO-23/12/00, que trata da aprovação da moção favorável a descriminalização do aborto pela plenária da $11^{\mathrm{a}}$ Conferência de Saúde. (Anexo I, p. 69)

A primeira, desfavorável ao aborto elogia em estádio 4 a defesa da vida das mulheres - perspectiva de coletivo. 
"Parabéns à Folha pelo editorial referente à aprovação pela $11^{\mathrm{a}}$ CNS da moção favorável à descriminalização do aborto ("Aborto e Crime", Opinião, pág. A2, 23/12). Embora discordando de que a questão deva ser tratada de modo prático, pois o direito das mulheres de interromper uma gestação indesejada ainda se coloca no plano filosófico e ético, a defesa da vida das mulheres, posição na qual se baseia o editorial, merece todo o nosso aplauso." FO- 02/01/2001

E a segunda peca por pretensão de validez- correção conforme evidencia a sua última frase

\begin{abstract}
"Também publicou no dia $\mathbf{2 3}$ de dezembro um excelente editorial ('Aborto e Crime') sobre o mesmo tema, superando o 'mito' de que esse não é um assunto para tempos natalinos" FO$02 / 01 / 2001$
\end{abstract}

\title{
DISCURSO 14
}

No ano de 2001 existe um grupo de cartas que discute o assunto a partir do Editorial "Luxo conservador", FO- 29/04/01. Na sua maioria são cartas que congratulam o editorial expondo sobre o aspecto amplo com que vem sendo tratando o assunto e sobre a questão da descriminalização do aborto. (Anexo I, p. 70)

\begin{abstract}
"A Folha tem adotado em relação ao debate do direito ao aborto um tratamento equilibrado e contemporâneo, destacando sempre as perversas consequências da ilegalidade dessa prática no Brasil" FO- 30/04/01
\end{abstract}

"Queremos cumprimentar a Folha pela seriedade com que tem focalizado a questão do aborto em seus editoriais, discutindo, dentre outros aspectos, sobre as consequências sociais da proibição do direito ao aborto em nosso país" FO- 30/04/01

"Quero parabenizar a Folha pela coragem com que vem apostando no debate sobre a necessidade de descriminalização do aborto em nosso país." FO- 02/05/01

Elas ainda enfocam a importância de uma discussão que interaja as perspectivas do falante coordenada com as perspectivas de observador e falante

\footnotetext{
"Uma postura humanista por parte da mídia é fundamental para que a questão do aborto seja debatida de forma serena e objetiva." FO- 20/04/01

"Ao referir-se à gravidade do problema da interrupção da gravidez no Brasil, o editorial "Luxo Conservador" enfatiza
} 
acertadamente as consequências, para a saúde das mulheres, do aborto praticado em condições inseguras, em especial as mortes $e$ as sequelas a que estão sujeitas principalmente as mulheres pobres, em decorrência da legislação proibitiva" FO- 20/04/01

" Acredito que essa atitude e o editorial 'Luxo conservador' (pág. A2, 29/4) contribuam não só com o debate mas com a conquista de um dos direitos humanos mais caros às mulheres, que é o de poder escolher sobre a sua vida reprodutiva." FO- 02/05/01

Somente uma carta manteve a discussão em um padrão de comportamento particular na relação eu-tu ao insistir numa representação de justiça que complementa ordem e obediência. Assim, acredita que as pessoas devem ser motivadas a agir em cooperação governada por interesses para não serem depois castigadas

\begin{abstract}
"Mas não se fala de um outro aspecto envolvido na questão: a morte de um ser indefeso. Antes de adotar uma posição diante do assunto, a Folha deveria mostrar às mulheres que elas, antes de desfrutarem da satisfação na relação sexual, precisam ponderar sobre as possiveis consequências decorrentes do ato, pois é melhor prevenir do que matar depois. As mulheres favoráveis à prática do aborto deveriam ser conscientizadas de que são donas de seu corpo, mas não podem decidir sobre a vida que nele se desenvolve. Deveriam ser alertadas de que $o$ aborto é um crime contra a vida de quem não está em condições de se defender. Não há palavra que defina essa agressão covarde que não seja o termo assassinato. É preciso valorizar a vida, não a morte." FO- 04/05/2001
\end{abstract}

São ainda reconhecidas uma carta, FO- 25/01/2001, que ironiza o termo conservador utilizado pela Folha de São Paulo que julgo faltar em pretensão de validez dado que não foram encontradas reportagens que fazendo alusão a isto. Ao final, um último diálogo entre leitores que usa o termo aborto para discussão político-partidária como pode ser lido a seguir

"Recentemente, a Direção Nacional do PT 'obrigou' o governador petista do Mato Grosso do Sul a desistir do convite feito a um representante do PFL para que integrasse a equipe do governo daquele Estado. As razões do 'veto' petista ao governador estariam ligadas, segundo o PT, a um conceito 'pefelista' de ação política e de ética incompatíveis com o 'padrão' ético e político do PT. Será interessante ver, nos próximos dias, se Lula e José Dirceu também irão 'obrigar' o deputado federal petista Professor Luizinho a desistir do projeto de lei de sua autoria que facilita o aborto. Todos os eleitores, especialmente os cristãos, saberão se - respeito à vida faz parte do 'padrão' ético do PT." FO$18 / 04 / 2001$ 
"Gostaria de perguntar ao sr. Francesco Scavolini ('Aborto', 'Painel do Leitor', pág. $A 3,18 / 4$ ) se seria ético condenar uma pessoa a crescer sem $\circ$ amor da família, virando mais um marginal na sociedade. Sim, pois como o sr. Scavolini é contrário ao aborto, deve preferir que as mães tratem seus filhos nãodesejados como bastardos em vez de evitar esse sofrimento. Entre viver indignamente e não viver, fico com a segunda alternativa. No mais, até o século retrasado, a Igreja Católica considerava os fetos de até 40 dias como 'sem-alma'." FO$18 / 04 / 2001$

O jornal O Estado de São Paulo não apresentou cartas de leitores discutindo este tema para os anos de 1998, 1999, 2000 e 2001. Ainda em 1998 encontramos algumas reportagens e artigos mas que não trouxeram o leitor a discussão.

\section{as drogas}

No final do ano 1995 e início de 1996 começaram as discussões para a alteração das penalizações com respeito às drogas. Isto significava fazer recair punições mais pesadas no traficante, variando o grau da pena conforme a qualidade do tráfico e não prender mais o usuário e, sim, restringir-lhe direitos.

Isto deveu-se a uma proposta feita pelo Conselho Federal de Entorpecentes COFEN para mudança da lei em vigência 6368/76, que dispunha sobre medidas de prevenção e repressão ao tráfico ilícito e uso indevido de substâncias entorpecentes ou que determinem dependência física ou psíquica. Dessa forma, o usuário ao invés de ir para a prisão, poderia prestar serviços à comunidade, ter limitação de fim de semana ou interdição de seus direitos.

Em 29 de outubro de 1996 Conselho Nacional de Política Criminal e Penitenciária propôs o projeto de lei 2684/96, que objetivava a alteração dos artigos $43,44,45,46,47$, 55 e 77, da seção II, das penas restritivas de direitos, do Código Penal Brasileiro, Decretolei n. 2.848 , de 7 de dezembro de $1940 .^{50}$ Este PL transformou-se na lei $9714 / 98$ em 25 de novembro de 1998.

De acordo com a redação essa lei , passou a constar do inc. I, art. 44, do CP, que

"as penas restritivas de direitos são autônomas e substituem as privativas de liberdade, quando aplicada pena privativa de liberdade não

\footnotetext{
${ }^{50}$ este assunto pode ser consultado no Brasil. Código penal. Organização dos textos, notas remissivas e indices por Juarez Oliveira. $6^{a}$ ed. São Paulo: Saraiva, 1991, p. 53-64.
} 
superior a quatro anos e o crime não for cometido com violência ou grave ameaça à pessoa ou, qualquer que seja a pena aplicada, se o crime for culposo".

Assim, a ampliação das alternativas à prisão permitia, no caso de crimes de menor gravidade, impor restrições aos direitos do condenado, que não o estigmatizasse com a prisão e permitisse uma maneira mais rápida e efetiva de reintegração social.

A lei atual sobre entorpecentes, lei 10.409/02, somente foi editada em 11 de janeiro de 2002 e dispõe sobre a prevenção, o tratamento, a fiscalização, o controle e a repressão à produção, ao uso e ao tráfico ilícitos de produtos, substâncias ou drogas ilícitas que causem dependência física ou psíquica, elencados pelo Ministério da Saúde.

Ainda sobre este assunto, no período investigado foi constituída a Comissão Parlamentar de inquérito - CPI do Narcotráfico em 09 de dezembro de 1999. Essa comissão tinha a finalidade de apurar organizações que atuavam no narcotráfico no Estado de São Paulo, suas relações com roubo de cargas, assassinatos, lavagem de dinheiro e demais atividades criminosas, assim como o envolvimento, a participação ou a colaboração de agentes públicos e órgãos estatais nas ações do tráfico de drogas.

O relatório final de investigação da comissão foi aprovado em 28 de junho de 2001. Durante um ano e nove meses ela examinou dados obtidos com a quebra do sigilo bancário, fiscal e telefônico de pessoas suspeitas de envolvimento com o narcotráfico e o crime organizado e, apresentou uma relação de indiciados da qual faziam parte deputados, delegados, desembargadores, juizes, policiais civis e militares de 17 estados do Brasil.

\section{Leitores e discursos}

A análise deste tema apresenta algumas peculiaridades. Pouco foi registrado da presença da igreja, judiciário, governo e organizações não-governamentais.

No geral, o tema é pouco provocativo e não manteve polêmica mais evidente no percurso dos anos analisados sendo tratado mais com um olhar para grupos envolvidos do que refletidos para papéis sociais mais amplos.

Interessante notar que a busca do jornal O Estado de São Paulo levantou uma série de cartas da seção "São Paulo Reclama", com queixas voltadas para o cotidiano do leitorcidadão: a rua, o bairro, o transporte, sendo a droga aí referida de forma distanciada do centro de discussão. 


\title{
DISCURSO 1
}

Esta seção traz duas cartas enviadas no ano de 1996 para a Folha de São Paulo e a reflexão dirigida pelo leitor à cada uma delas.

A primeira, FO- 01/0196, é uma carta de Fernando Gabeira, deputado federal (PVRJ) criticando um artigo de Fernando Molica, "Entre apitos e balas" publicado em dezembro de 1995. Gabeira alude sobre Molica insinuar um certo favorecimento dos ricos em detrimento dos pobres na nova política de drogas: proposta de mudança de grau de penalidade para usuários. (Anexo I, p. 72)

"Os primeiros [os ricos - LMP] brincam com a polícia que tenta reprimir a prática: usam apitos para avisar o resto do grupo que está na hora de apagar o baseado.

Os outros não têm lá muito tempo para brincadeiras. Entre eles, as drogas são, em primeiro lugar, produtos que devem ser comercializados. Na falta de outras opções, é um trabalho. Só que, por aqui, a polícia não é recebida com apitos, mas com balas.

Os primeiros vivem na mesma órbita dos legisladores. Ao deixar de punir o consumo, nossos parlamentares atendem a um certo clamor social e previnem eventuais problemas domésticos." FO$22 / 12 / 95$

Gabeira desenvolve sua reflexão discutindo em função de princípios de justiça, estádio 5, pós-convencional. Mantendo interação das perspectivas do falante e do mundo apresenta alguns dados sobre o assunto

\begin{abstract}
"Basta fazer um levantamento no fórum do Rio para se constatar que os processos contra consumidores de drogas se concentram nas áreas mais pobres. (..)Na verdade, tanto no campo do consumo como no do tráfico quem vai para a cadeia são os mais pobres. Como explicar que a maioria dos 'traficantes', condenados por um crime que supõe organização e capacidade material, seja na verdade de quase indigentes? (...) Na verdade, o consumo transcende os limites do Posto 9." FO- 01/01/96
\end{abstract}

Ao mesmo tempo, não mantém o mesmo estádio quando faz referência às classes ricas argumentando em uma perspectiva egocêntrica:

\footnotetext{
"Nas ricas, funciona o suborno. (...) Molica parte do princípio de que quem fuma maconha é a classe média abastada." FO$01 / 01 / 96$
}

A resposta do jornalista ao seu questionamento, nega que tenha incorrido em erro quanto à correção na sua pretensão de validez e que os dados oferecidos reforçam a 
importância de se continuar a discussão sobre o assunto que não se resolve unicamente com a aprovação desse projeto de lei.

"Os dados citados na carta a respeito da condição social dos
presos por tráfico reforçam a importância de não deixar que a
discussão sobre drogas seja encerrada com a eventual
aprovação do projeto." FO- $01 / 01 / 96$

$\mathrm{Na}$ outra carta, o leitor Israel Alves de Araújo diverge da manifestação dos advogados criminalistas Maurides de Melo Ribeiro e Alberto Zacharias Toron, presidente do Conselho Estadual de Entorpecentes de São Paulo, exposto por eles na reportagem "Para advogados, apitar em Ipanema é exercer cidadania" (Anexo I, p. 73-74).

Enquanto os depoimentos da reportagem são colocados em nivel pós-convencional, estádio 6, em uma contextura que não se baseia no aspecto do direito positivado e, sim, na validade de princípios éticos universais.

\begin{abstract}
"É tudo uma questão de interpretação. Numa visão legalista e isolada da lei, tais condutas seriam criminosas. Mas se a lei for interpretada à luz do contexto social, elas constituem-se em manifestações legítimas da cidadania", afirma o advogado criminalista Maurides de Melo Ribeiro." FO- 10/02/96
\end{abstract}

"A Constituição assegura às pessoas o direito de emitir suas opiniões e críticas. É legítimo externar opinião sobre a conveniência ou não de criminalizar-se o uso de drogas" Alberto Zacharias Toron FO- 10/02/96

O leitor, que considera que apitar na praia de Ipanema é crime e não exercício de cidadania, argumenta em nivel convencional, estádio 4 na perspectiva da legitimidade a qual o direito é cumprir com os deveres contratados, ou seja, em uma interação guiada por normas

"Ouso divergir: o caso não se trata de apitar ou não. É notório que os supostos apitadores são, também, usuários da droga fumada na praia de Ipanema, e a conduta dos portadores de apitos consiste em apitar, quando da aproximação da polícia, com o intuito de avisar aos demais usuários. $E$, com isso, evitar o flagrante por porte e uso de entorpecentes, o que ainda é crime no Brasil. Portanto, é fácil observar que a conduta dos apitadores de Ipanema pode ser perfeitamente enquadrável no artigo 14 da lei 6.368/76. Apitar na praia de Ipanema, quando se reúnem pessoas que fazem uso de drogas, não é cidadania, mas crime previsto no artigo 12 , parágrafo $2^{\circ}$, 1 , da lei $6.368 / 76$." FO- 26/02/96 


\title{
DISCURSO 2
}

Outras cartas foram também publicadas neste ano e neste discurso 2 apresento o conjunto delas fragmentadas em várias reportagens. (Anexo I, p. 76-78)

A primeira está assinada pelo embaixador do Peru a partir de uma publicação de um texto traduzido do jornal inglês "The Independent". Ele esclarece ser um texto equivocado e podendo comprometer o presidente Fujimori. O diálogo eu-tu aqui defrontado traz dúvidas quanto a pretensão de correção.

A segunda carta trata de uma representação contra o filme "Trainspotting" referida em FO- 30/11/96 na reportagem "Drogas são o 'alvo' brasileiro" descrevendo uma cena do filme

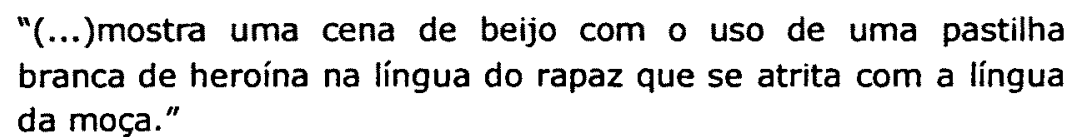

A partir do pressuposto incentivo que a cena pode trazer ao uso de drogas, utiliza uma fala em diálogo eu-tu, na perspectiva de ser bom e preocupar-se com as outras pessoas, estádio 3 , para justificar seu ato

\begin{abstract}
"O sócio da Pandora Filmes, patrocinador do 'Trainspotting', deve visitar urgentemente um centro de recuperação de drogados levando consigo sua filha de dez anos para sentir a decadência da juventude com o uso de drogas. Não defendo a censura, mas, sim, a juventude, incluindo a filha do sócio da Pandora Filmes" FO- 02/08/96
\end{abstract}

A terceira correspondência também faz uma crítica à idéia de incentivo ao uso de drogas Aqui há referência às tiras de quadrinhos de Glauco e o seu personagem "Doy Jorge". O leitor utiliza-se da ironia fazendo diversos questionamentos numa perspectiva egocêntrica

\footnotetext{
"mostram o lado gozado (?), descontraido (?) e informal (?) das drogas. É preciso fazer esse tipo de humor? $E$ a Folha tem mesmo que publicá-lo?" FO-27/11/96
}

O Estado de São Paulo para o mesmo período apresentou muita correspondência do espaço denominado "São Paulo Reclama" pertencente ao caderno Cidades. As cartas fazem referência à drogas, não como objeto da comunicação como já foi referido na 
introdução deste tema. Para a única carta com interlocutor reconhecido o artigo por ele referido não foi localizado no banco de dados. (Anexo II, p. 28-30)

\section{DISCURSO 3}

Esta seção trata de um caso ocorrido no início do ano de 1997, no centro da cidade de São Paulo - Rua Amaral Gurgel, FO- 02/02/97. A reportagem do jornal Folha de São Paulo flagrou dois policiais militares agredindo um adolescente em uma batida policial. Há uma descrição detalhada das cenas assim como apresentava imagens do ato. As análises são de leitores comentando o fato dois dias depois. (Anexo I, p. 79-80)

A primeira, assinada pela deputada federal Telma de Souza, adjetiva o fato como chocante e usa do ocorrido para uma cobrança política em uma perspectiva de respeito por outras pessoas como fim e não como meio, estádio 6, pós-convencional.

\section{"(...) Será que o mesmo empenho usado para a reeleição não poderia ser usado para proteger nossas crianças?" FO- 02/02/97}

O outro leitor faz uma reflexão oposta à anterior, em um discurso de preservação do sistema social, estádio 4 , convencional, com matiz do estádio anterior no que diz respeito em conservar a confiança dos parceiros, a lealdade, em face das pessoas orientadas em função de recompensa e castigo.

\footnotetext{
"Espero que a exagerada e sensacionalista reportagem sobre a blitz contra drogas na rua Amaral Gurgel (31/1) não seja causa de punição dos policiais envolvidos e, principalmente, não reduza a presença da Policia Militar na região, onde diariamente dezenas de mulheres que dirigem seus veiculos desacompanhadas são vítimas de assalto nos semáforos por esses menores infratores. É lamentável que a reportagem nunca tenha denunciado ou flagrado a atuação dos menores, colaborando, assim, com a defesa dos direitos das cidadãs." FO- 02/02/97
}

Um último leitor elogia a atuação corajosa dos repórteres. Este leitor toma uma perspectiva do mundo, questionando a ação da instituição policia

\footnotetext{
"É duro acreditar que apesar desse jornalismo arrojado, investigativo e denunciativo a truculência continue desesperando nossas vidas. Enquanto isso, os verdadeiros bandidos continuam fabricando reeleições. Parabéns, Folha!"
}

O discurso está orientado em manter o bem-estar da sociedade, estádio 4, convencional. Ele adota o ponto de vista do sistema e conserva as relações individuais em 
termos do lugar neste sistema: a truculência versus verdadeiros bandidos- "mesmo os repórteres cumprindo o seu papel os políticos não cumprem os deles".

\section{DISCURSO 4}

Este discurso procede de um artigo da articulista da FO, Marilene Felinto, "Vagabundagem universitária começa no trote", publicada em 25 de fevereiro de 1997. Dois eleitores opinam em falas controversas. (Anexo I, p. 80-81)

O primeiro reflete a fala da articulista para a idéia do trote como

"(...) uma forma de traficantes se apoderarem de novos viciados em drogas e de jovens rapazes 'ficarem' com as novas meninas" FO- 06/03/97

e termina em uma perspectiva orientada em função de princípios que as pessoas podem concordar ou não, compondo uma sociedade destinada a ter práticas leais ou benéficas

\section{"Ainda temos uma pequena parcela de universitários que se preocupam com a sociedade e exercem de fato sua cidadania." FO- 06/03/97}

O outro realiza uma fala incisiva com a finalidade de manter a instituição - USP, estádio 4, convencional. Sua perspectiva traz um certo egocentrismo do estádio 2 terminando em uma fala eu-tu: é preciso reconhecer as necessidades e interesses próprios. (Anexo I, p. 80-81)

\footnotetext{
"(...) Será que ela sabe o esforço dessa massa de 'vagabundos, elitistas, movidos a MTV e shopping centers'? Certamente que não. Mostra, assim, que não conhece a concorrência atual nas universidades públicas para cursos como medicina, engenharia mecatrônica, odonto, jornalismo, entre outros (...)." FO06/03/97
}

\section{DISCURSO 5}

Em 02 de junho de 1997, o caderno Folhateen do jornal FO, publicou uma matéria cujo objeto era discutir a cola ${ }^{51}$ na escola (Anexo I, p. 83-85). Dois leitores conversaram entre si sobre o assunto. Um tomou de exemplo a orientação de punição do EEPSG Caetano de Campos para fazer críticas pessoais ao colégio, utilizando uma fala negativa de 
estádio 3, ou seja, a regra de ouro aplicada: não fazes para o outro o que não queres que façam para ti, ou ainda, os professores e a diretoria não respeitam os alunos e vice e versa

\begin{abstract}
"(...)e a propósito de o regimento da EEPSG Caetano de Campos não prever punição para tal ato, gostaria de acrescentar que não só não há punição como não há aula, higiene, material didático, salas decentes, professores ou alunos interessados. Em compensação, tem de sobra falta de respeito dos professores para com os alunos (e vice-versa) e drogas sendo consumidas e distribuídas na escola. Tudo a olhos vistos da diretoria incompetente, que nada faz." FO- 16/06/97
\end{abstract}

O seguinte, responde negando as denúncias também em estádio 3 na idéia de "nós cumprimos nosso papel"

\begin{abstract}
"O missivista destila, ainda, sua irreverência e injúria, citando 'falta de respeito dos professores para com os alunos (e viceversa)', o que não corresponde à realidade da relação professoraluno nesta escola. A acusação de consumo e distribuição de drogas na escola põe sob suspeita, ou acusa de omissão, a própria vigilância diuturna que policiais militares destacadas para cá fazem no portão de entrada e mesmo no pátio interno. Informamos que a direção deste estabelecimento não recebeu nenhuma denúncia sobre os fatos expostos na carta, o que aguarda seja feito diretamente pelo zeloso cidadão leitor deste jornal." FO- 18/06/97
\end{abstract}

\title{
DISCURSO 6
}

Uma leitora troca opinião com uma sugestão dada em um artigo intitulado "As mulheres e a aids". (Anexo I, p. 85)

"O poder público tem de agir rapidamente, com a criação de campanhas que abordem a situação especifica das mulheres e estimulem de maneira eficaz a prevenção." FO- 02/08/97

Diante dessa fala, a leitora amplia o discurso, e insere o homem em uma condição de igualdade na discussão de idéia de direito do estádio 5 , pós-convencional, de que as regras devem ser apoiadas nos interesses da imparcialidade dado que são resultante de um contrato que coloca todos em iguais condições. Ela faz a superação da estrutura anterior de lealdade para o principio de justiça.

"por que não incluir os parceiros homens junto com as mulheres na discussão sobre a epidemia, desde que são esses os principais

${ }^{51}$ verbete Aurélio: Bras. Gir. Copiar clandestinamente num exame escrito; filar(FERREIRA 1999). 
responsáveis pela transmissão sexual do HIV para as mulheres _seja como usuários de drogas injetáveis, bissexuais e outros homens sexualmente ativos?" FO- 09/08/97

\section{DISCURSO 7}

Este discurso é uma das raras referências ao momento de mudança legal com a proposta do PL 2684/96. O senador Romeu Tuma (PL-SP) reprova a imprecisão da nota publicada no caderno Brasil. (Anexo I, p. 86)

\footnotetext{
"Recém-aprovado na Câmara, o projeto que cria penas alternativas às de prisão corre o risco de ser desfigurado no Senado. O relator Romeu Tuma (PFL-SP) já decidiu protelar seu parecer. Alega que pretende ouvir representantes da segurança pública." FO- 02/09/97
}

Aduz que ela teve a intenção de colocá-lo em um agir conforme as normas, estádio 4 , convencional (ter uma atitude em manter o funcionamento institucional ao decidir ainda discutir o tema com representantes da segurança pública).

Tuma responde ter consciência da necessidade de mudança de norma e da incapacidade do Estado em dar cumprimento legal ao vigente até aquele momento. Tenta usar de uma regra para o exame de normas do estádio 5 ao aguardar manifestação de magistrados mas, na realidade, sua resposta guarda características do estádio 4, que tem uma representação de justiça em conformidade ao sistema de normas existentes (ao solicitar parecer de magistrados) ao invés de interagir suas perspectivas de falante e do mundo de um estádio 5, pós-convencional (ouvir todos os implicados na questão para poder estabelecer uma nova validez ideal que condiga com a realidade social).

"Foi isso o que ouvi, mais uma vez, de dignos e experientes membros do Judiciário. É tanta a preocupação que, por meio de suas entidades de classe, constituíram um grupo de estudos para examinar o problema e dar-me colaboração, pois fui designado para relatar o projeto de lei 2.684/96 que aumenta para 14 o número de penas alternativas. Acredito na importância de aguardarmos por alguns dias a manifestação dos magistrados, antes da apresentação do relatório, para elaborá-lo com mais propriedade. Não me consta que tanto os juizes como o deputado Hélio Bicudo representem o sistema de segurança pública ou tenham interesse em procrastinar a aprovação daquele projeto de lei." FO- 05/09/97 


\title{
DISCURSO 8
}

Em setembro de 1997, um novo comandante-geral assumiu a Policia Militar (PM) do estado de São Paulo, coronel Carlos Alberto de Camargo. Em decorrência deste fato houve uma reformulação nos quadros e operações da PM. Um leitor escreveu para a FO fazendo críticas às declarações fornecidas à imprensa.

\begin{abstract}
"e à ação da sua tropa, violentando e constrangendo cidadãos nas ruas de São Paulo ao abordar e revistar todos os veículos, indiscriminadamente: realmente é preciso repensar a polícia. Operações como essa não servem para nada além de perturbar o já caótico trânsito e constranger ilegalmente cidadãos." FO25/09/97
\end{abstract}

O leitor trabalha um único aspecto das situações apresentadas, percebe que o sistema de "blitz" constrange o cidadão mas em uma relação de um espectator- perspectiva de observador e participante, que aplica a regra de ouro dizendo: se eu não sou bandido então eu não quero ser parado na rua. Ao mesmo tempo, lendo-se as reportagens, o leitor falha em verdade ao referir ser necessário repensar a polícia, pois as propostas do novo comando prometem ser inovadoras e tentam estabelecer uma interação dos falantes com o mundo da vida. Assim, dois dias depois, no mesmo espaço do leitor surge a réplica dada pelo relações públicas da PM

"Temos consciência de que uma abordagem policial, mesmo que
efetuada dentro dos mais estritos principios de legalidade e
respeito, causa incômodo, porém é um eficiente meio de
prevenir o crime, por meio da apreensão de armas, drogas e da
captura de criminosos procurados. Quanto ao fato de o
missivista alegar que as operações não servem para nada,
informamos que já na primeira delas foram apreendidas 9 armas
de fogo, lavrados 6 flagrantes de porte de entorpecentes e 73
outros, por crimes diversos. É importante que se saliente que as
medidas implantadas pelo atual comandante-geral não se
resumem a isso. A principal mieta é a implantação do
policiamento comunitário, que paulatinamente mudará a cultura
da segurança, tanto por parte do policial como do cidadão." FO-
$27 / 09 / 97$

Dois aspectos interessantes se destacam: um quanto a fala que justifica a ação dentro dos princípios da legalidade, estádio 4 , convencional, enquanto outra agrega sinais de estádio 5, pós-convencional, que pretende através de um novo agir superar estruturas internas dos policiais e cidadãos mudando assim as expectativas de ambos: aproximar uma validez de fato - a legalidade da ação da polícia em validez social - o cidadão próximo do 
policiamento comunitário. Isto é comprovado e detalhado no artigo "Grupo vai planejar polícia de quarteirão" (Anexo I, p. 88)

\begin{abstract}
"A outra prioridade anunciada por Camargo é a implantação do policiamento comunitário, que ficará sob responsabilidade do chefe do CPM, coronel Valdir Suzano.

Suzano formará uma comissão com representantes da sociedade civil para implementar na prática o policiamento.

Até ontem, a comissão já contava com a participação da ABI (Associação Brasileira de Imprensa), OAB (Ordem dos Advogados do Brasil), Fiesp (Federação das Indústrias do Estado de São Paulo) e da Pastoral do Menor.

A idéia de Camargo é que cada dupla de policial seja responsável pelo patrulhamento de uma pequena área, conhecendo a população e seus problemas." FO-20/09/97
\end{abstract}

\title{
DISCURSO 9
}

Este próximo discurso é resultado de um conjunto de reportagens editadas em 22 de setembro de 1997 que trataram de pesquisa feita pelo Grupo Interdisciplinar de Estudos de Álcool e Drogas do Instituto de Psiquiatria do Hospital das Clínicas da Faculdade de Medicina da Universidade de São Paulo (Grea), para conhecer e medir o uso de drogas entre os alunos da universidade. (Anexo I, p. 86-87).

Um leitor parabeniza o propósito e a forma de abranger o assunto e trazer a discussão em âmbito mais ampliado, FO- 23/09/97. Outro leitor, provocado por uma fala do Diretório Acadêmico Livre (DCE) da Universidade de São Paulo(USP)

"O uso de drogas é uma questão de foro íntimo. Se for por prazer, depressão ou mesmo uma busca da morte, é um problema individual. $O$ tráfico é condenável, mas o DCE não tem posição oficial de como deve ser combatido."

discute o aspecto coletivo e não individual da decisão da pessoa em utilizar drogas

"(...)A preocupação do coordenador do DCE me pareceu bastante equivocada. $O$ uso de drogas, lícitas ou ilicitas, deixou de ser uma questão de foro intimo a partir do momento em que a sociedade foi convocada para pagar as contas das consequências do consumo delas." FO- 28/09/97 


\section{DISCURSO 10}

Em novembro de 1997, um conjunto de rock denominado Planet Hemp foi preso acusado de fazer apologia da droga na letra de suas músicas. Eles foram indiciados pelos artigos 12 e 18 da lei de entorpecentes 9368/76.

"Art. $12-$

\section{(...)}

$\S 2^{\circ}$ - Nas mesmas penas incorre, ainda, quem:

I - induz, instiga ou auxilia alguém a usar entorpecente ou substância que determine dependência física ou psíquica;

II - utiliza local de que tem a propriedade, posse, administração, guarda ou vigilância, ou consente que outrem dele se utilize, ainda que gratuitamente, para uso indevido ou tráfico ilícito de entorpecente ou de substância que determine dependência física ou psíquica;

III - contribui de qualquer forma para incentivar ou difundir o uso indevido ou o tráfico ilícito de substância entorpecente ou que determine dependência física ou psíquica."

"Art. 18 - As penas dos crimes definidos nesta lei serão aumentadas de um terço a dois terços:

I - no caso de tráfico com o exterior ou de extraterritorialidade da lei penal;

II - quando o agente tiver praticado o crime prevalecendo-se de função pública relacionada com a repressão à criminalidade ou quando, muito embora não titular de função pública, tenha missão de guarda e vigilância;

III - se qualquer deles decorrer de associação ou visar a menores de 21 (vinte e um) anos ou a quem tenha, por qualquer causa, diminuída ou suprimida a capacidade de discernimento ou de autodeterminação;

IV - se qualquer dos atos de preparação, execução ou consumação ocorrer nas imediações ou no interior de estabelecimentos de ensino ou hospitalar, de sedes de entidades estudantis, sociais, culturais, recreativas, 
esportivas ou beneficentes, de locais de trabalho coletivo de estabelecimentos penais, ou de recintos onde se realizem espetáculos ou diversões de qualquer natureza, sem prejuízo da interdição do estabelecimento ou do local."

A polêmica criada surgiu com o argumento da controvérsia entre os artigos da lei 6368 e o exposto no artigo $5^{\circ}$ da Constituição de 1988 (Brasil 1988)

"Art. $5^{\circ}$ Todos são iguais perante a lei, sem distinção de qualquer natureza, garantindo-se aos brasileiros e aos estrangeiros residentes no país a inviolabilidade do direito à vida, à liberdade, à igualdade, à segurança e à propriedade, nos temos seguintes:

\section{(...)}

IX- é livre a expressão da atividade intelectual, artística científica e de comunicação, independentemente de censura ou licença;"

Várias cartas foram publicadas mas somente duas tiveram interlocutores identificados. A primeira acusa um editorial do jornal Folha de São Paulo, FO- 15/11/97, em manter uma postura mal disfarçada da mesma apologia à maconha que o grupo de rock praticou. (Anexo I, p. 93)

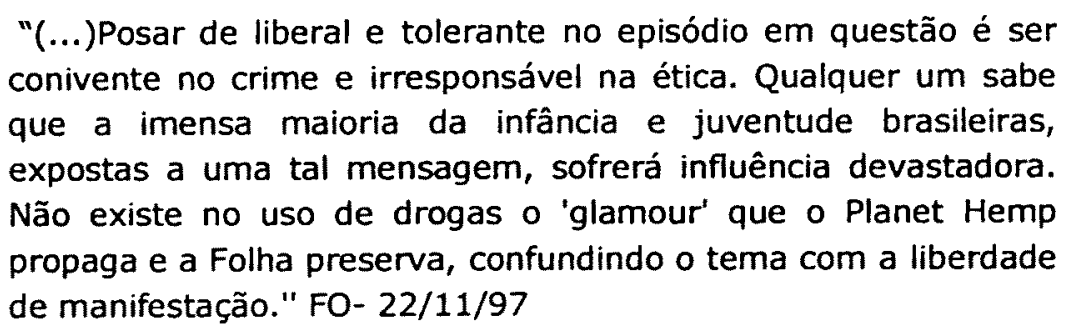

O leitor discute o problema somente com respeito ao aspecto dos perigos da publicidade da maconha nos grupos adolescentes, tem um comportamento socialmente leal a seguir as regras que as pessoas esperam que ele e os adolescentes sigam; ser bom aos olhos dos outros e aos próprios olhos. Dessa forma, sua leitura do editorial falha na correção e ele não consegue observar outros aspectos ali expostos, construídos em expectativas de comportamento que confrontam uma validez social com a validez existente na construção de um ideal baseado em regras de princípios, pós-convencional, estádio 5/6. (Anexo I, p. 93)

"A detenção dos integrantes do grupo procurou, como já é de costume, atingir apenas alvos fáceis (porque ostensivos) no combate a uma prática com a qual o mundo contemporâneo tem 
convivido de maneira bastante conflituosa. A verdade é que as sociedades ainda não criaram consensos significativos quanto aos procedimentos para coibir ou mesmo tolerar o uso de entorpecentes. O pior é que a repressão às vezes acaba por chamar uma atenção excessiva para fatos que talvez estivessem destinados a não ter repercussão.

O episódio torna, pois, mais do que oportuna a tarefa de rever a atual legislação sobre uso de tóxicos; alerta também para a importância de a sociedade não transigir na defesa contínua da liberdade de expressão, sem a qual a democracia fenece." FO$15 / 11 / 97$

No final do mesmo ano uma outra correspondência discute dois artigos publicados ainda sobre o comportamento do Planet Hemp: FO- 22/11/97, "Sem passaporte para o crime" do professor Celso Ribeiro Bastos e FO- 26/11/97 "O Planet Hemp e a hegemonia do cinismo" do dr. Alberto Zacharias Toron já presente na análise do discurso 1. (Anexo I, p. 95-98)

Ambos trazem leituras diferenciadas sobre o assunto. Ambos mantêm linguagens diametralmente opostas. Enquanto Celso Bastos discorre sua argumentação em estádio 4, convencional e 5 pós-convencional, pois ao tempo em que adota o ponto de vista do sistema que define regras, complementa-se na perspectiva dos acordos formais do contratoo ponto de vista moral é o ponto de vista legal;

"A lei pode ser dura. Não obstante isso, em vigor, tem de ser
cumprida. Quem não gosta das leis em vigor deve lutar
politicamente pela sua mudança e, se se considerar atingido por
qualquer lei de forma abusiva, procurar a reparação pelo
Judiciário. Esse é o funcionamento normal de um Estado
democrático de Direito. Se os roqueiros não se enquadram nessa
normalidade, têm, inevitavelmente, de arcar com as
consequências. E ponto final." FO- $22 / 11 / 97$

Toron vai além do aspecto liberdade de expressão per si refletindo sobre a qualificação dessa liberdade a partir de regras de princípios que reconhecem as pessoas como fins e não como meios. Critica o discurso estádio $4 / 5$ dos positivistas que conserva as relações sociais em termos de sistemas, cumprindo o seu dever em manter o bem estar da sociedade, ou, discursa que direito é cumprir com os deveres com os quais concordou com a finalidade de manter a instituição Estado.

"É evidente que a liberdade de expressão não é ilimitada. Imagine que alguém resolva sair por aí pregando o extermínio de judeus e negros sob o argumento de constituirem "raças inferiores", "malignas" ou coisa parecida. (...)Quem aplaudiu a ação da polícia, reduzindo o acontecimento a mera aplicação da 
lei penal, por uma questão de coerência, deveria reclamar a prisão das pessoas citadas e, também, de uma legião de pessoas que pensam da mesma maneira.

O discurso moralista parte de premissas falsas, como a de que "o uso das drogas destrói a vida", "perverte as relações humanas", "corrói a vida familiar" e "inspira atitudes criminosas". Colocações genéricas como essas servem para criar - alarmismo, mas ao confundir as inúmeras e diferenciadas drogas, cujos efeitos e sintomas são as vezes até opostos, caem no descrédito. Assim, uma coisa é a maconha, outra, bem diferente, o crack ou a heroína. Depois, são médicos que estão afirmando que a Cannabis, ao invés de incitar um comportamento criminoso, tende a suprimi-lo na exata medida que induz à letargia.

Podemos até discordar do que pensam alguns médicos, políticos, cientistas sociais e juristas, mas uma sociedade democrática não pode amordaçar os que discordam das idéias dominantes, sob o risco de se criar algo ainda pior, que é o totalitarismo engessador das inexoráveis mudanças sociais. Aliás, a liberdade filosófica teve por precursores toda a sorte de heréticos que o braço secular castigou durante todo o curso da Idade Média." FO- 26/11/97

O leitor comenta a favor do artigo de Toron e contrário à Celso Bastos em uma perspectiva de princípios, pós-convencional, estádio 5

"O fato de a Constituição considerar o tráfico ilícito de entorpecentes e drogas afins crime inafiançável não pode servir de pretexto para restringir a liberdade de expressão. Fazer música é bem diferente de traficar." FO- 05/12/97

Existem ainda duas cartas que conversam entre si mas o objeto principal do discurso não são as drogas e sim a retirada da feira de artesanato da Praça da República, da cidade de São Paulo. ${ }^{52}$

\section{DISCURSO 11}

$\mathrm{O}$ discurso inicial de 1998 refere-se a um leitor concorde com o artigo "O avesso do direito" do advogado Rodrigo da Cunha Pereira. Segundo este, todo desejo acaba por

\footnotetext{
52 À semelhança, outras duas discutem um artigo que trata da abertura legal dos cassinos e não mantêm conversa interleitores mas com publicações do jornal: uma carta fala sobre a censura de livros de uma editora e outra sobre um artigo do sr. Ermírio de Morais tratando do emprego no setor automotivo e o impacto do uso do álcool nos acidentes de trânsito (Anexo I, p. 99-100). Para este mesmo ano O Estado de São Paulo ainda mantém a característica já referida sobre o espaço "São Paulo Reclama". Uma trata da peruada, festa dos alunos da Faculdade de Direito da Universidade de São Paulo e uma última sobre um jogador de futebol denominado Reinaldo e o uso de drogas, ambas não analisadas.
} 
reclamar um direito na forma de determinar um meio em restringir impulsos que inviabilizem o convívio social. (Anexo I, p. 102)

"Sem esses referenciais, não seria possível a ordenação jurídica nos moldes em que está. É que somos sujeitos do desejo e, portanto, determinados por ele. E ele, muitas vezes, precisa mesmo de um limite externo _ a lei jurídica." FO- 06/06/97

O leitor, assim como o subscritor do artigo, parte do princípio que o ser (estádio 1, onde as perspectivas eu-tu mantêm um padrão de comportamento particular - o desejo) para que conviva em outro estádio do quadro de perspectivas, necessita entrar em acordo com outras pessoas e estabelecer uma regra concreta que, no futuro, pode ser determinada sob o ponto de vista de um sistema de regras definidas. Para este caso as perspectivas de Selman ajudam a aclarar a reflexão: perspectivas pensadas em termos unilaterais do nível 1 quando se tornam auto-reflexivas exigem uma habilidade em se sair mentalmente fora de si e adotar uma perspectiva de segunda pessoa. Então, elas conscientizam a impossibilidade de fazer coisas que pode não querer, nível dois, e passam a manter uma aparência visível para exibir-se como pessoa boa e guardar uma realidade oculta dentro de si (o desejo) .

"O direito entende que o ato final do desejo deve ser
'destipificado' da alegórica categoria criminal. Pode-se
'destipificar' o ato. Mas não se pode negar a existência de um
desejo, a não ser produzindo uma neurose. O advogado Rodrigo
da Cunha Pereira, em 'o avesso do direito' (Cotidiano, 'Data
Venia', 6/6), lembra bem o cristianismo: não desejar a mulher
do próximo, não desejar a morte do próximo etc... Lutar sempre
contra os meus desejos naturais (Spinoza), pois o mal vem do
desejo (Schopenhauer). Essa neurose que vivemos do 'querer é
poder' vem em última análise propiciando o crescimento do
consumo de drogas em todo o mundo. Que ninguém se engane
com falso moralismo. A mesma indústria que fomenta o sexo
alimenta paralelamente o uso de drogas, armas etc." FO-
$13 / 06 / 98$

O leitor remete esta argumentação para discutir o crescimento do consumo de drogas na relação do uso do desejo

"A mesma indústria que fomenta o sexo alimenta paralelamente o uso de drogas, armas etc." FO- 06/06/97

DISCURSO 12

"Sobre a coluna 'Gol, álcool e violência', de Luiz Caversan (pág. 1-2, Opinião, 19/6), gostaria de acrescentar um elemento que 
faltou em suas observações: responsabilidade paterna. Em nossos dias existe uma tendência em jogar para a sociedade e para o governo toda a responsabilidade sobre as mazelas nacionais, fazendo-nos esquecer que, se cada um de nós fizesse a sua parte, o todo seria melhor." FO- 01/07/98

Esta é uma carta de estádio 3, convencional. O leitor tenta aclarar um aspecto não envolvido por Luiz Caversan em seu artigo: "a responsabilidade paterna", ser importante em seu papel de pai, ou filho, ou amigo. Simultaneamente, também é fundamental que todos mantenham em funcionamento a instituição. Ou seja, ele tem a perspectiva do indivíduo com relação aos outros somada a um diferencial societário do acordo mas a autoridade ainda se manifesta em um arbítrio supra individual. (Anexo I, p. 103)

Neste ano de 1998, poucas cartas foram localizadas no banco de dados da FO. Registro uma discutindo resultados, um ano depois, da pesquisa relatada no discurso 9. Nesse momento, novos resultados são apresentados e Gilberto Dimenstein os examina no artigo "Estudo conclui que uso de álcool dobra durante curso".

Um leitor concorda com a leitura de Dimenstein de que o aumento de consumo não é uma fatalidade e, sim, "um reforço de uma tendência". Esta conversa não apresenta reflexões éticas e sim estatísticas do assunto e existe um erro de correção por parte do leitor. A fala

\section{" (...) Absolutamente falaciosa a inferência de que o número de usuários de drogas salte de $39 \%$ para $82 \%$ só por causa do curso médico." FO- 15/08/97}

não condiz com o texto de Dimeinstein

"De cada 100 alunos de medicina no sexto ano da faculdade, 82 bebem com frequência _o que não significa um caminho inexorável ao alcoolismo, mas o reforço de uma tendência.

No primeiro ano do curso, essa média é de 39 em cada 100 alunos." FO- $12 / 08 / 98^{53}$

\footnotetext{
${ }^{53}$ A carta de esclarecimento da segurança pública do Rio de Janeiro com respeito à matéria divulgada sobre eles pelo jornal não foi avaliada, pois trata da violência e não do objeto em estudo.
} 


\title{
DISCURSO $13^{54}$
}

A carta que trata este discurso foi publicada no ano de 1998 no O Estado de São Paulo. Um médico faz referência ao artigo "Violência gerada pelas drogas" de Luiza Eluf. (Anexo II, p. 31-33)

$\mathrm{O}$ artigo levanta questões a respeito de o presidente Fernando Henrique Cardoso criar a Secretaria Especial da Política Nacional do Controle de Drogas para coordenar as ações nesta área em todo o território nacional. A fala, empregada na perspectiva do estádio 5 , coloca a responsabilidade de ação na figura do Estado no sentido de cumprir os deveres do contrato.

\begin{abstract}
"Alguém precisa informar o nosso bem-intencionado presidente de que o controle do uso e do tráfico de drogas só pode ser feito com o aparelhamento sistemático do Estado e de seus funcionários, isto é, da Polícia Federal, das polícias estaduais, da rede pública de saúde, das escolas, enfim, de todos os serviços básicos, para que possam cumprir suas obrigações $e$, efetivamente, reduzir ao mínimo o flagelo das drogas. Caso contrário, secretaria nacional nenhuma levará a cabo a tarefa." FO- 03/04/98
\end{abstract}

O leitor coaduna com o artigo também nesta perspectiva, ambos no estádio pósconvencional de perspectivas formais, ambos reconhecem a inabilidade do governo em lidar com o problema. Também os dois mantêm características em perspectivas sociais do estádio 4, pois não fazem a interação das perspectivas do falante e do mundo sem assumir a perspectiva do outro, terceira pessoa na reflexão.

\begin{abstract}
"Uma Secretaria Especial da Política Nacional do Controle de Drogas, não tenho dúvidas, será mais um escritório burocrático entre tantos outros na capital federal, inócuos sorvedouros do dinheiro público. Pessoas habilitadas a reprimir o tráfico, cuidar dos dependentes e prevenir sua disseminação, sobretudo nas escolas, ou seja, investimentos em segurança pública, saúde e educação respectivamente, também não tenho dúvida, reduziriam em muito o problema e o retirariam do rol das grandes preocupações da sociedade brasileira." FO- 05/04/98
\end{abstract}

\footnotetext{
${ }^{54}$ A carta levantada de $O E$ para este ano não pode ser analisada, pois o artigo de referência não foi localizado no banco de dados do jornal. A presença de cartas do São Paulo Reclama não foi evidenciada para este ano.
} 
DISCURSO 14

O discurso em pauta transcorre no jornal FO em 1999. Trata-se de duas leitoras discutindo o tabagismo em função de uma foto publicada no caderno Mais, FO 08/08/99. (Anexo I, p. 106)

Uma leitora critica a foto por esta estar relacionada à figura de intelectuais em um momento em que o mundo se movimenta contra o cigarro. Ela exige da FO uma coordenação de suas ações dentro de um sistema estabelecido e mutuamente compartido, nível 3, do estádio 5, convencional, com visas em proteger seus próprios direitos e os direitos dos outros.

"No mínimo nojenta e de um profundo mau gosto a capa do caderno Mais! de 8/8. Deu até para sentir o mau cheiro dos cigarros acumulados no cinzeiro e no prato. Associar esse produto nefasto a uma conversa de intelectuais _como se o cigarro fosse um ícone dessa 'elite'_.. é, no mínimo, falta de bom senso e desafinação com todo um movimento em nivel mundial contra seu uso." FO- 15/08/99

O diálogo apresentado pelo outro insiste na mesma qualidade de discurso mas a favor do cigarro.

\begin{abstract}
"(...) a capa de Mais! de $8 / 8$ está afinada com a resistência ao patrulhamento mundial contra o cigarro. $\dot{E}$ mil vezes preferivel fumar cigarro a consumir drogas, um mercado em franca expansão." FO- 18/08/97
\end{abstract}

DISCURSO $15^{55}$

$\mathrm{O}$ artigo de Marcelo Coelho publicado no caderno Ilustrada de 08 de dezembro de 1999, "Proibição das drogas é obra de drogados", provocou a discussão com dois leitores. Ele desenvolve seu pensamento em três colocações: acredita que proibir o uso de drogas faz aumentar o tráfico; declara ter usado cocaína sem se viciar e que o problema não está na legalização ou não da droga mas em outra esfera de discussão. Marcelo coloca-se na perspectiva de um ego observador em interação interpessoal e coordena a sua fala com o mundo da vida. Conclui dizendo que não será uma norma justificada em princípios tão restritos como o mal que o entorpecente faz que irá solucionar a questão, ou melhor, uma

\footnotetext{
${ }^{55}$ Para este ano O Estado de São Paulo apresenta algumas cartas que não permitiram análise ou por afastarem-se do objeto de estudo ou por não ter sido localizado artigo de referência.
} 
norma baseada em cálculo racional de utilidade para drogados se pensada na relação: quanto mais proíbo mais tenho acesso. (Anexo I, p. 106-107)

\begin{abstract}
"De minha parte, experimentei cocaína umas quatro ou cinco vezes. Essa droga não corresponde ao que se espera de uma droga: ausência do mundo, inconsciência, falta de culpa, fantasia. Teve em mim o efeito de acelerar o tempo: eu piscava os olhos, e duas horas tinham passado. Seu poder excitante acarretava uma contrapartida muito incômoda: uma espécie de mal-estar nas pernas, do gênero que se sente em viagens demoradas de avião. Os músculos não relaxam, senti um contrapelo na carne, uma aflição ácida nos nervos. É possivel que a cocaína exerça, sobre outros organismos, efeitos de que nem desconfio. Tenho certeza, entretanto, do seguinte fenômeno: a adição, o vício, a dependência que uma droga produz não depende de algum segredo químico que exista dentro dela. O dependente de uma droga (não sei no caso do crack) está doente de outra coisa, está doente de si mesmo, não da substância que consome.
\end{abstract}

\title{
(...)
}

O que existe, no horror a drogas como cocaína e maconha e na tolerância frente ao álcool e ao cigarro, é talvez uma rivalidade geracional; a desconfiança mítica de que com determinados produtos químicos os jovens tenham acesso a prazeres que desconhecemos. Ridiculas as iniciativas que apostam, contra as drogas, no "esclarecimento" da juventude. Esse suposto "esclarecimento" não é resposta ao problema real, que é o de legalizar ou não. Legais, o álcool e o cigarro são objeto de campanhas muito eficazes a respeito de seus malefícios. Cocaina e maconha não precisam ser proibidas para que se "esclareça" o usuário. Não; a proibição não faz sentido. É irracional. Deve ter sido obra de drogados." FO- 08/12/99

Os leitores se colocam em situação diferenciada: um não aprova o texto e o outro sim. O que não concorda traz um discurso eu-tu, pois apesar de achar que a proibição não é a solução, a sua reflexão se mantém em perspectiva interpessoal

"Será que ele nunca teve na sua família ou nas suas relações de amizade alguém que literalmente acabou com sua vida ou com a da sua família por conta da droga?" FO- 11/12/99

O favorável agrega em sua reflexão a idéia de vício ao consumismo. A falta de maior explicitação do assunto impediu análise mais detalhada. 
DISCURSO 16

A primeira carta do ano 2000 traz a reflexão auto-critica a partir de reportagem sobre o conflito entre as favelas Heliópolis e Paraguai na cidade de São Paulo. (Anexo I, p. 108-109)

A carta mostra uma reflexão transparecendo a passagem do estádio 2 - o direito é agir para satisfazer os interesses e necessidades próprios, para o estádio 4 - o direito é manter a instituição como um todo considerando as conseqüências do "E se todos fizessem o mesmo?"

\begin{abstract}
"Há pouco tempo, essas notícias se referiam ao Rio de Janeiro, e nós, passivamente, assistíamos 'de camarote' o que acontecia no Estado irmão sem tomarmos a mínima providência para prevenir o exemplo do banditismo em nosso território. Aí está! E agora, como vamos combater tal criminalidade?" FO- 06/03/00
\end{abstract}

Sua conclusão coloca na mão do Estado a responsabilidade de solucionar a questão, estádio 2 de autoridade de pessoa de referência.

"Até quando vamos ficar nas mãos de bandidos? Com a palavra o secretário da Segurança Pública." FO- 06/03/00

\title{
DISCURSO 17
}

Uma única carta discute a reportagem "Viúva, jovem, futuro incerto", FO23/04/00, que mostra a vida de mulheres de traficantes. A leitora pondera em nível convencional estádio 3 sua preocupação com as pessoas envolvidas com traficantes: mulheres e filhos. É uma fala benevolente que consegue avaliar o outro sem referenciar o sistema de relações entre eles. (Anexo I, p. 111-112)

\footnotetext{
"A reportagem sobre as jovens viúvas (Cotidiano, 23/4) mostra a que ponto chegou o tráfico de drogas. É lamentável saber que uma jovem de 24 anos já acumula a amarga experiência de ser viúva de traficante, com dois filhos pequenos para criar, tendo que viver às escondidas com os pequenos, sem a menor condição de thes oferecer educação, segurança e vida com dignidade." FO- 30/04/00
}

\section{DISCURSO 18}

Esta carta traça um paralelo entre o uso de drogas e o álcool. O artigo de referência, o editorial "Droga esquecida", FO- 30/9/00, conta que em um estudo feito no Brasil, 87\% 
dos usuários de drogas são alcoólatras. Numa perspectiva social, o leitor analisa as pessoas que consomem álcool numa perspectiva do estádio 4, convencional, no sentido que, mesmo ficando bêbados à semelhança dos drogados, sentem-se socialmente bem, pois sua ação é legalmente aceita pelo sistema e portanto isto está de acordo com o contrato. (Anexo I, p. 121-122)

"(...) Ainda assim, graças aos impostos recolhidos pelo governo, tem seu consumo não só tolerado como largamente estimulado. Afinal de contas, qual a diferença, em termos de prejuízos sociais, entre quem produz, vende e consome bebidas alcoólicas e os assim chamados 'traficantes e usuários de drogas'? É simples: uns prejudicam a si mesmos e à sociedade; os outros apenas deixam de cumprir o segundo item. E o mais engraçado é ver pessoas que adoram tomar um belo porre e ainda assim se consideram muito diferentes daqueles que eles entendem como 'drogados'." FO- 09/10/00

\section{DISCURSO $19^{56}$}

O artigo "Laços de família" de Gilberto Dimeinstein, aborda os aspectos psicosociais das drogas

"A discussão sobre a liberalização das drogas se torna grave não por causa dos traficantes, mas devido aos estímulos da sociedade_a começar da família.

A família moderna não tem tempo. Pai e mãe trabalham, chegam cansados em casa e, como é previsivel, não querem mais aborrecimento. Imaginamos compensar a falta de atenção pagando terapeutas, professores particulares e brinquedos caros. Também, nesse jogo de compensações, dizemos poucos "nãos"." FO- $19 / 11$

e a carta FO- 23/11/00 argumenta em estádio 4, chamando a responsabilidade da sociedade para enfrentar a questão no sentido de preservar o sistema social e nos cumprimentos de suas obrigações. (Anexo I, p. 122-123)

"(...) Realmente, não é possivel continuar tratando a questão do consumo de drogas com tanta superficialidade e hipocrisia como fazemos hoje. Como psiquiatra envolvido na recuperação de

\footnotetext{
${ }^{56} \mathrm{O}$ conjunto de cartas FO- 25/04/00, FO- 27/04/00, FO- 09/05/00, FO- 17/05/00 não foram submetidas a análise. Elas decorrem de um artigo denominado "Drogas e prioridades" do jornalista e escritor Olavo de Carvalho. O artigo falha na pretensão de validez ao vincular o consumo de drogas com a esquerda e pelo tal gerou estas cartas que ou denúnciam a falha ou se aproveitam da mesma discursando sobre tema distante ao ora analisado (Anexo I, p. 110-111). Assim também não foram analisadas outras cartas que não se caracterizam como discurso ou não tiveram artigos de referência localizados tanto para a FO como para OE.
} 
drogados, sinto-me como se estivesse 'enxugando gelo', já que a capacidade de a sociedade produzir problemas nessa área é muito maior do que a de prover recursos para superá-los."

\title{
DISCURSO 20
}

O ministro-chefe do Gabinete de Segurança Institucional da Presidência da República e general de divisão do Exército Alberto Mendes Cardoso, em artigo denominado "Considerações sobre "Traffic", tece uma série de considerações sobre este filme candidato ao prêmio Oscar 2001. Sua análise é ampla, levantando questões na perspectiva da terceira pessoa que coordena simultaneamente as do si-próprio do(s) outro(s) do nível 3 e em ação mutuamente compartida universalmente. Ele abrange aspectos internacionais e brasileiros envolvidos no tráfico de drogas, percebendo e acatando princípios universais e referindo, em especial, a liberdade e os valores sociais. (Anexo I, p. 125-127)

\begin{abstract}
"Por fim, mas sem esgotar o rol de mensagens, a fita demonstra o aspecto fundamental do diálogo na família. Junte-se à família a escola e _sob os pontos de vista de orientação moral e de valorização da vida_a religião, teremos a base para a formação integral da pessoa.
\end{abstract}

Na questão de drogas, como em toda matéria política, a grande ferramenta da liberdade é o cidadão consciente e bem informado. O filme "Traffic" alimenta um debate necessário, que vem sendo empreendido crescentemente pelos mais diversos setores da sociedade brasileira. É um belo filme." FO- 25/03/01

A partir dessa publicação, duas cartas são enviadas ao jornal FO. A primeira atevese somente em um aspecto e transpôs o uso de drogas e suas conseqüências coletivas para o consumo e suas conseqüências coletivas sócio-econômicas

"(..) um pouco reducionista. Quando alguém compra refrigerante, tênis, remédio, computador etc. também não está sustentando a injustiça socioeconômica entre indivíduos e paises _a mesma desigualdade que está no cerne do binômio produção/consumo de 'I_? ${ }^{\prime 57}$ FO- 28/03/01

O outro leitor, relata ter usado o filme como instrumento de reflexão com o filho $\mathrm{e}$ concorda com o aspecto do diálogo com a família e escola mas, em uma fala de estádio 5 ,

\footnotetext{
${ }^{57}$ assim está digitado no banco de dados.
} 
aceita que as pessoas adotem uma variedade de valores e opiniões e propõe uma lei de cálculo de utilidade geral

\begin{abstract}
"Então, por que não vender as drogas e cobrar impostos que financiem os gastos do Estado com as consequências delas? As drogas, hoje, estão muito mais acessiveis do que podemos imaginar. Não sugiro praças ou lugares especiais para viciados, porque acho uma hipocrisia combatermos apenas algumas drogas." FO- 28/03/01
\end{abstract}

\title{
DISCURSO 21
}

$\mathrm{O}$ artigo do Prof. Marco Segre, FO- 31/05/01, gerou duas cartas com argumentações opostas. (Anexo I, p. 127)

Enquanto a primeira não acredita no argumento da proibição, nem na descriminalização das drogas, colocando o processo de decisão do seu uso ou não sobre o indivíduo e seu direito individual de dispor sobre seu próprio corpo, análise feita em estádio 2, pré-convencional: perspectiva individualista concreta porque está ciente de que todos tem direitos individuais

\begin{abstract}
"(...) A descriminalização das drogas mantêm um dos negócios mais lucrativos do mundo. O pseudo-argumento de manter na ilegalidade certos tipos de droga que alteram a consciência das pessoas, com o suposto intuito de proteger a saúde do cidadão, não resiste à menor análise. Há que se respeitar o direito do individuo de dispor de seu próprio corpo da maneira que bem entender. $O$ Estado não pode tratar pessoas adultas $e$ conscientes como se fossem crianças que ainda não sabem discernir o bem do mal" FO-03/06/01
\end{abstract}

A segunda sustenta apoiar a descriminalização como meio de solução para a questão, ou seja, diferentemente da anterior, que enfoca no individuo, para esta o Estado é responsável sobre a questão e deve decidir baseando-se em principios universais

"(...)Penso que o Brasil deva estar atento e procurar somar com - bloco europeu, que vê na descriminalização da droga o caminho para a almejada saúde social das nações. (...)Não devemos fazer apologia do uso da droga, mas, sim, vê-la realmente como problema de saúde e tentar resolver o problema funesto de sua comercialização com racionalidade $e$ no verdadeiro interesse da humanidade, não no interesse dos grupos que só lucram com a manutenção desse 'status quo'." FO- 08/06/01 


\title{
DISCURSO 22
}

Em agosto de 2001 um editorial da Folha trouxe comentários sobre como a revista britânica 'The Economist' abordava a questão das drogas em caráter utilitarista, estádio 5, pós-convencional. (Anexo I, p. 128-129)

\begin{abstract}
"(...) Para "The Economist" há razões teóricas e práticas a reclamar a liberação. Em termos filosóficos, e segundo a tradição utilitarista de John Stuart Mill (1806-1873), o Estado não tem o direito de intervir para impedir que individuos façam algo que os prejudique. "Sobre si mesmo, sobre seu corpo e sua mente, o indivíduo é soberano", proclamou o filósofo.
\end{abstract}

Para a revista, não há diferenças filosóficas significativas entre injetar uma dose de heroína e escalar uma montanha. Ambos os comportamentos apresentam risco. Devem preocupar as companhias de seguro e as mães, mas devem ser tolerados pelo Estado democrático.

O argumento prático diz respeito à distribuição dos prejuízos. Segundo a publicação, eles "recaem de forma desproporcional sobre os paises pobres e sobre pessoas pobres em paises ricos". Nas nações miseráveis que produzem as drogas, verifica-se 0 surgimento de grupos tão poderosos que ameaçam o Estado e corrompem instituições políticas. Nos países ricos, são os indivíduos pobres que têm maior probabilidade de serem empregados no comércio de drogas e, assim, de parar na cadeia." FO- 01/08/01

Frente a este comentário, um leitor médico escreve discordando sobre o assunto. Ele responde a uma fala de estádio 5 com reflexões do estádio 4, convencional: deve-se cumprir o dever na sociedade, apoiando a ordem social e mantendo o bem estar dela mesma e do grupo. A fala conserva as relações individuais em termos de lugar no sistema, ela restringe as conseqüências às agressões locais.

"(...) Discordo radicalmente da tese defendida pela revista. Quero dizer a todos os defensores da descriminalização das drogas que um viciado não causa mal apenas a si próprio. As páginas policiais estão repletas de casos de pessoas que cometeram os mais bárbaros crimes sob os nefastos efeitos das drogas, ao contrário do praticante de esportes radicais, que coloca em risco apenas a sua própria vida."FO- 05/08/01

Três dias depois, surge uma conversa interleitores. Um leitor identificando-se também como médico, discorda do primeiro pontuando as mesmas razões apresentadas pelo editorial. Ao apresentar-se como da mesma área de atuação, este situa o seu papel 
dentro do sistema, ou seja, usa de um argumento de estádio 4 para ser reconhecido. A seguir, discursa em perspectiva do prioritário-em-face-da-sociedade.

\begin{abstract}
"(...) concordo plenamente, como médico, que a Folha e outros órgãos da imprensa brasileira aceitem o desafio de contribuir com o debate inevitável da legalização das drogas. Traficantes, economistas de paises produtores, bancos, policiais especializados, profissionais de saúde que exploram comercialmente a dependência química, entre outros, não podem sobrepor seus interesses econômicos e opiniões pessoais ao debate democrático que aponte alternativas ao fracasso inaceitável do modelo repressão-abstinência. A sociedade brasileira não pode continuar pagando por algo que não funciona." FO- 08/08/01
\end{abstract}

\section{DISCURSO 23}

Este segmento discute uma matéria publicada no caderno Folhateen, "Da malhação à ferveção", sobre a efedrina, substância contida em alguns suplementos dietéticos. O repórter escreve esclarecendo sobre o assunto e a matéria é vista sob aspectos diferentes por dois leitores. (Anexo I, p. 129-130)

As duas cartas trabalham em pontos eqüidistantes. A primeira, escrita por um pai de adolescente, tem um discurso egocêntrico. Ele não identifica a importância de se esclarecer sobre os perigos destes suplementos e sim considera somente os aspectos de consequiências para si na sua atitude personalística, não observa os aspectos orientadores e elucidativos da reportagem.

"(...)Mas, certamente, surtiu um efeito contrário, porque sua apresentação foi mais uma apologia às drogas ali citadas do que propriamente um desaconselhamento. Fala-se, em muito poucas linhas, dos efeitos adversos daquelas drogas, ao passo que, nas duas primeiras páginas, a reportagem mostra como os jovens adquirem, como administram (em comprimidos, em chicletes etc.), cita os efeitos gostosos das drogas (descarga de adrenalina, euforia etc.) e traz depoimentos de consumidores. Não tenho idéia de como o jornal poderia agir para mitigar os efeitos desastrosos que a reportagem com certeza já causou e ainda causará aos 'teens'. Augusto Pinheiro pode estar carregado de boas intenções, mas pode saber que, na realidade, mesmo que involuntariamente, transformou-se num espetacular marqueteiro dos traficantes de drogas. Quero deixar registrado aqui o meu protesto contra esse tipo de reportagem e pedir mais cuidado aos editores do jornal. FO- 10/08/01 
O outro, em uma visão de médico anestesista, amplia a opinião para uma perspectiva de estádio 4. Fundamentando em uma perspectiva de terceira pessoa e para fora de seu sistema particular, aplaude o alerta destas medicações e a necessidade de as pessoas tomarem conhecimento sobre o assunto.

\begin{abstract}
"(...) não posso deixar de registrar minha preocupação com o uso indiscriminado de drogas que fazem parte do nosso arsenal terapêutico. Medicações como a efedrina, um vasopressor comumente utilizado em anestesiologia, e a quetamina, um agente indutor e analgésico, são administradas somente sob estrita monitorização e vigilância do médico. Podem ser extremamente perigosas se usadas sem supervisão do especialista. O texto alerta para os riscos do consumo dessas medicações de forma concisa e descomplicada, mostrando ao leitor leigo o potencial devastador dessas duas drogas. Colocamos uma chamada para a reportagem da Folha em nosso site, www.anestesiologia.com.br." FO- 12/08/01
\end{abstract}

\title{
DISCURSO 24
}

Uma artigo assinado por Wálter Fanganiello Maierovitch, secretário nacional antidrogas da Presidência da República no período de 1999-2000, FO- 22/08/01, levantou um número maior de discussões. $\mathrm{O}$ texto apresentado é abrangente e faz uma comparação entre as políticas antidrogas propostas por Portugal e Estados Unidos e as possibilidades abarcadas no projeto lei em tramitação no Senado. Ele evidencia a importância da ampliação da legislação em uma análise pós-convencional, onde mostra o reconhecimento das leis existentes, os conflitos que elas geram (estádio 5) e a importância de se analisar a questão respeitando os princípios éticos universais contidos no artigo $5^{\circ}$ da Constituição Federal. (Anexo I, p. 131-135)

Os leitores discutiram a questão sob dois aspectos. Um olhando na perspectiva de estádio 4, reconhecer o seu dever na sociedade e manter o sistema

"(...) Maierovitch termina por prestar um desserviço à prevenção de drogas no Brasil, pois vai contra o brilhante trabalho dos policiais militares.

O fato de policiais militares fardados entrarem em contato com os alunos estreita a comunicação entre polícia e escola, entre polícia e alunos e entre polícia e pais. Ou seja, a PM passa a realizar também um trabalho de prevenção em prol de toda uma sociedade carente de cuidados e de informação. 
O problema das drogas é tão danoso para nossa sociedade que ficamos chocados com as posições assumidas por certas pessoas, que, por serem formadoras de opinião e por terem a responsabilidade de prestar bons serviços à comunidade, deveriam cerrar fileiras nessa luta, em vez de trabalharem para dividir e enfraquecer as boas iniciativas." FO- 26/08/01

O leitor estava se referindo ao Proerd- Programa Educacional de Resistência às Drogas e à Violência e esta carta gerou mais três reflexões contrapondo as duas perspectivas acima expostas.

A primeira compreende o aspecto dos princípios universais abordados por Maierovtch discordando de atuações pontuais

\begin{abstract}
"(...) que propõem uma terceira via como política pública de drogas no Brasil _baseada na ampliação e na humanização dos serviços dedicados a usuários de drogas. Essa política é frontalmente contrária à que tenta limitar a questão ao binômio repressão/abstinência, cujo principal disseminador é a política externa norte-americana de 'guerra contra as drogas'. O Proerd nada mais é do que a versão 'educacional' dessa política que coloca policiais para 'ensinar' crianças a 'dizer não às drogas'."FO- 26/08/01
\end{abstract}

A segunda correspondência, ao ter vivenciado a atuação do Proerd na escola do filho, discute a importância de se trabalhar a reflexão e não a autoridade como instrumento para levar seu filho a definir sua posição frente às drogas. Critica a imposição de um padrão particular com respeito à autoridade, arbítrio externamente sancionado do estádio 1 , exercido pelos policiais

"(...)A educação escolar deve ser restrita àquelas pessoas que, além de ter formação e discernimento, saibam lidar com crianças e adolescentes, o que não é simples. Quero que meu filho compreenda os malefícios causados pelas drogas $e$ espontaneamente diga não a elas, e não que seja simplesmente doutrinado a não usá-las." FO- 03/09/01

A última, de um representante da polícia, responde ao leitor concordando com o papel dos educadores ao tempo que se justifica usando de uma autoridade de arbítrio supraindividual de lealdade

"(...) 0 trabalho realizado pelo Proerd é extremamente preventivo, pois é cada vez maior o número de jovens que, já nas salas de aula, tomam contato com as drogas, muitas vezes por omissão dos próprios pais e por falhas no sistema de educação. São inúmeros os elogios recebidos da comunidade a cada Proerd realizado. E existem muitas solicitações à espera de 
atendimento por parte de nossos policiais, o que demonstra que, se não estamos certos no exercício da função pedagógica, existe um 'quase desespero' de pais e professores ao verem o flagelo do tóxico invadindo os recintos mais sagrados. A Policia Militar realiza incontáveis outros atendimentos de cunho social por estar permanentemente voltada para a comunidade e por ser solicitada pelo cidadão em muitos lugares onde constitui a única face do Estado." FO- 05/09/01

\title{
DISCURSO 25
}

Um artigo contrário a descriminalização, "Droga na escola", de Arnaldo Niskier, é o assunto gerador desse discurso. Ele faz uma reflexão da importância do papel do educador na questão das drogas na escola pontuando o papel da escola como polícia ou como educadora. (Anexo I, p. 135-136)

\begin{abstract}
"(...) O medo de perder a autoridade ou de trocá-la por uma situação nova do mestre conselheiro _ou orientador ou facilitador_da matéria está criando embaraços. Para a compreensão adequada do fenômeno das drogas, seria conveniente estimular a discussão entre os alunos. A transdisciplinaridade ajudaria a entender melhor os estragos da droga e os seus efeitos nocivos.
\end{abstract}

De nada (ou pouco) adianta a campanha de rádio e $T V$, pais que tratam os adolescentes de forma violenta ou fazem chantagem emocional. O que poderia funcionar muito bem é esse tipo de conversa orientada, dentro dos parâmetros da pedagogia moderna, para atenuar o que hoje é um flagelo instalado na educação brasileira." FO- 28/09/01

A primeira carta discorda da posição de Niskier em expulsar o aluno e levar o caso simplesmente à polícia. Ele acredita no papel da escola em um nivel mais elevado que o de estádio 4, onde ela simplesmente cumpre papéis generalizados, definindo interações de estádio 5 e 6

" (...) O papel da escola é muito mais abrangente. A repressão a um adolescente 'desviado' é um julgamento sumário de quem está em fase de afirmação e identificação social. O papel da escola é resgatar a sua auto-estima, orientá-lo, pô-lo em contato com a sociedade e buscar identificá-lo com seu grupo. Enquanto o problema das drogas for apresentado como caso de polícia, essa batalha estará perdida. $E$, na atual conjuntura, o papel da escola e do educador é muito mais importante que o de meros 'juizes da conduta moral'. E, a propósito, será que o aluno expulso pelo professor na década de 70 teve seu problema com 
as drogas solucionado ou foi apenas sujeira colocada embaixo do tapete?" FO- 30/10/01

A outra toma um pequeno aspecto do agir em papéis do estádio 3

\begin{abstract}
"(...) Em primeiro lugar, deveríamos pensar onde o jovem começa a fazer uso do álcool, que é a porta de entrada de todas as outras drogas. Na maioria das vezes, ele tem seus pais como modelo. No dizer de Fred Astaire, 'a mais árdua tarefa das crianças hoje em dia é aprender boas maneiras sem ver nenhuma'." FO- 30/10/01
\end{abstract}

\title{
DISCURSO 26
}

O artigo do psiquiatra Ronaldo Laranjeira faz uma exposição de motivos sobre a questão do controle social e político no consumo de álcool. (Anexo I, p. 136-137) Sua fala coloca-se no estádio 5, abrangendo o aspecto da utilidade - o maior bem para o maior número de pessoas e conclui ao final

\begin{abstract}
"(...) A compensação social pelo dano ambiental que o álcool produz só será uma realidade quando convencermos a sociedade e o mundo político de que controlar esse produto é uma garantia de que o bem comum deve prevalecer sobre um produto e sua indústria." FO- 29/10/01
\end{abstract}

Um leitor congratula-se com o artigo e ressalta a importância da sociedade brasileira participar nesse processo, ou seja, cumprir com o papel de deveres ao apoiar a ordem social e ao manter o bem estar da sociedade e do grupo, estádio 4 .

"(...) Tragédia essa que se alastra sob as vistas grossas do governo e da sociedade civil, estimulada por diversos agentes, entre os quais a mídia eletrônica e as empresas de publicidade. É hora de enfrentar o problema, com coragem e sem hipocrisia, pois, só para começo de conversa, sabemos que com menos de $R \$ 5$ qualquer brasileiro pode ficar embriagado. E que milhões de litros de cachaça e cerveja são consumidos diariamente neste pais." FO- 29/10/01

De forma semelhante, ainda dentro deste discurso, foi tratada a conversa entre a carta FO- 20/12/01 e o artigo do jornalista Vinícius Torres Freire. Também discutido em termos utilitaristas do estádio 5 , diz

" (...) Quanto à pinga ou a qualquer outra bebida alcoólica, não seria o caso de taxá-las mais _para elevar o preço_e de colocar em prática campanhas publicitárias que informassem os males que causam à saúde, à familia e à sociedade em geral_como se faz com o cigarro? As drogas e o álcool, com seus efeitos 
maléficos, ceifam, com as mortes precoces, vidas ainda em

formação e deixam até filhos órfãos de pais vivos." FO- 20/12/01

O bloco de discussão entre profissionais de saúde mental e representante do Movimento Nacional da Luta Antimanicomial, não foi analisado, pois o objeto não é a droga. A discussão aborda tanto drogas como a internação de casos psiquiátricos (nesta ocasião está sendo votado o projeto de lei do deputado Paulo Delgado, com substitutivo do senador Sebastião Rocha, que limita e regulamenta as internações psiquiátricas). (Anexo I, p. 140-141)

Outras cartas de FO e de OE, não foram discutidas por não apresentarem condições de discurso. Ressalto que mais uma vez para este ano de 2001, os leitores de OE apresentam o mesmo comportamento que o indicado anteriormente.

\section{a eutanásia}

A questão da eutanásia é tema discutido internacional e nacionalmente durante o periodo dessa investigação. Países como Austrália, França e Estados Unidos começam a ter pareceres favoráveis dados por comitês médicos reconhecidos cientificamente e tribunais. A Holanda teve aprovação dada pelo Câmara Baixa do Parlamento da Holanda em 2001.

No Brasil, a questão começa a ser mais discutida a partir da revisão do Código Penal em abril de 1999 e uma das propostas da comissão revisora sugere a diminuição da pena para casos de eutanásia praticados por parentes ou pessoas que tenham ligações emocionais com a vítima. Até então, o código não previa o crime de eutanásia e os casos existentes eram enquadrados na prática de homicídio simples, parte especial, art.121, Título I, dos crimes contra a pessoa, capitulo I, dos crimes contra a vida (Brasil 1991; p72).

\section{Leitores e discursos}

Este tema, apesar de tratado pela mídia por diversas oportunidades, pouco instigou a conversação dos leitores de ambos os jornais como pode ser apreciado pelo número de cartas apresentadas a seguir. 


\section{DISCURSO 1}

Em decorrência das discussões da proposta do novo Código Penal brasileiro, o jornal Folha de São Paulo, publica um artigo do repórter Carlos Eduardo Lins da Silva "O direito de morrer com dignidade".

O texto, argumentado em base de princípios, comenta como a questão da eutanásia foi vista através dos tempos até a atualidade, descrevendo quais as posições dos diversos países com respeito a isso. Carlos Eduardo, discute, dentre outros, o ponto de vista religioso como um dos obstáculos para a aprovação de sua legalização.

\section{"(...) Além de obscurantistas argumentos religiosos, colocam-se dois obstáculos racionais à legalização da eutanásia. Um é o de que, em caso de avaliações médicas equivocadas, ela pode eliminar vidas desnecessariamente. $O$ outro é o de que ela pode justificar crimes (...).FO- 16/04/99}

e conclui que a proposta no novo código não é pela eutanásia mas pela permissão de deixar de manter a vida de uma pessoa por meio artificial e que a discussão deste assunto já permitiu a diminuição do sofrimento para pacientes terminais. (Anexo I, p. 144145)

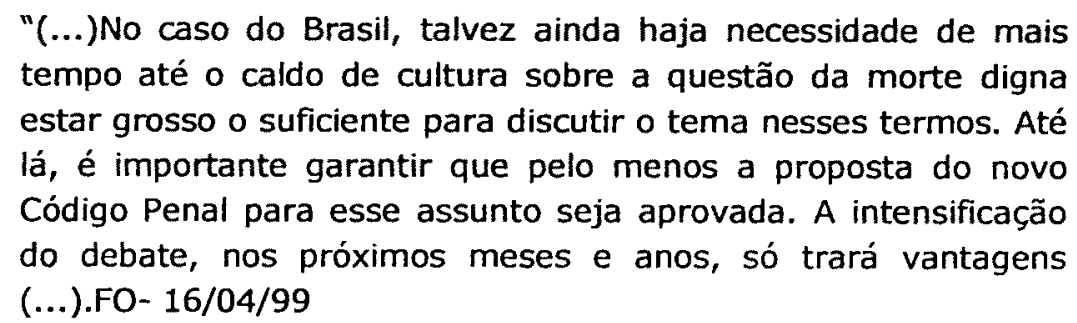

A carta que dialoga com o repórter diz-se favorável a eutanásia. Ela discute o processo em base de princípios de igualdade de direitos humanos, nível pós-convencional, estádio 6. Sua reflexão parte do confronto eutanásia $X$ precariedade do sistema de saúde, sugerindo que é necessário antes pensarmos em uma vida digna para podermos então pensarmos em uma morte condigna.

\footnotetext{
"(...)Entretanto, acredito que no Brasil, por causa da precariedade de nosso sistema de saúde, do baixo poder aquisitivo da população e das cláusulas leoninas constantes dos planos de saúde, a eutanásia, sob outra denominação, já venha sendo praticada, em larga escala. (...) Enquanto o 'andar de cima' teoriza, o 'andar de baixo' pratica. Que hipocrisia! Penso que esse debate só terá realmente sentido quando todos os cidadãos, independentemente da classe social a que pertençam,
} 
puderem, efetivamente, ter, primeiro, o direito a uma vida

digna, para ai sim ter dignidade na morte." FO- 25/04/99

\title{
DISCURSO 2
}

Uma reportagem do jornal O Estado de São Paulo publicou uma declaração de d. Cláudio Humes à Comissão especial de reformulação do Código Penal Brasileiro refutada por ele a seguir em carta enviada para o Fórum de Leitores. (Anexo II, p. 40-41)

\begin{abstract}
"A Igreja apóia o desligamento de aparelhos que mantêm artificialmente a vida de pacientes irrecuperáveis, informou ontem o arcebispo de Fortaleza, dom Cláudio Hummes, à comissão especial que prepara a reformulação do Código Penal. A pedido do arcebispo, a comissão deve voltar a discutir os casos de aborto legal. O desligamento, chamado de ortotanásia pelos técnicos, deixará de ser crime, segundo propõe a comissão." OE$11 / 03 / 98$
\end{abstract}

Segundo a versão de d. Cláudio, o repórter fez conclusões errôneas sobre seu depoimento

\begin{abstract}
"(...)Disse, sim, que a Igreja defende não haver necessidade ética do que se chama "excesso terapêutico", ou seja, pode-se renunciar a certas intervenções médicas já inadequadas à situação real do doente, porque não proporcionadas aos resultados que se poderiam esperar ou ainda porque demasiado gravosas para ele e para a sua familia (...). OE- 20/03/98
\end{abstract}

O diálogo construido para este esclarecimento tem características de relação eu-tu nas falas de falante-ouvinte sem a perspectiva de um observador e em uma visão cosmológica transcendental. $\mathrm{O}$ que está determinado pela autoridade, o dito pelo papa, no processo de decisão pode ser acatado ou não e ainda ser avaliado em simetria de compensações: se eu seguir as normas terei recompensas, caso contrário o castigo, estádio 1 , pré-convencional.

"(...) Essa é a doutrina de João Paulo II, na sua encíclica Evangelium Vitae (1995) (...).OE- 20/03/98 


\section{a doação presumida de órgãos}

A sanção da lei 9434 de $04 / 03 / 1997^{58}$, que dispõe sobre a remoção de órgãos, tecidos e partes do corpo humano para fins de transplante, estabeleceu a doação presumida de órgãos do projeto lei proposto pelo deputado federal Darcy Ribeiro. Ela também prevê que a realização de transplantes ou enxertos de tecidos, órgãos ou partes do corpo humano só poderá ser realizada por estabelecimento de saúde, público ou privado, e por equipes médico-cirúrgicas de remoção e transplante previamente autorizadas pelo órgão de gestão nacional do Sistema Único de Saúde.

\section{Leitores e discursos}

Durante este período os diálogos posicionam-se sobre esta imposição legal e também a fatos relacionados à fila única de espera para transplantes. No início de 1998, um ano depois de sancionada a lei de doação presumida, uma pesquisa do InformEstado mostrou que a porcentagem de paulistanos que manifestavam intenção em doar órgãos, $79 \%$, caía para $57 \%$ quando investigada a opinião destes doadores com respeito a doação compulsória $^{59}$. O que encontramos para análise são, principalmente, discussões relativas às polêmicas que o assunto gerou: o aspecto compulsório, as dificuldades de captação de órgãos pelo sistema e, apesar da fila única, a manutenção de privilégios dos receptadores nos serviços privados.

\section{DISCURSO 1}

No ano de 1996, um grupo de médicos de equipes de transplantes de figado produziu um documento denominado "Consenso Estadual para Transplantes de Órgãos". Neste, eles estabeleciam uma distribuição de órgãos pelas equipes responsáveis por transplantes em São Paulo (Anexo I, p. 145-147). Elio Gaspari denunciou isto em uma reportagem sob título "Transplante de figado é 'privatizado' em SP". Nela ele fazia uma retrospectiva histórica do assunto demonstrando a atitude utilitarista disfarçada destes

\footnotetext{
${ }^{58}$ regulamentou a lei o decreto n. $^{\circ} 2268$ de 30 de junho de 1997 . Medida provisória ${ }^{\circ} 1896$ de 24 de setembro de 1999: na ausência de manifestação de vontade do potencial doador, a familia se manifesta.

${ }^{59}$ dados de pesquisa sobre esse assunto pode ser encontrado no artigo: Maioria que doaria órgãos diminui com lei: pesquisa do InformEstado mostra que porcentagem de paulistanos que manifestam a intenção de ceder órgãos após a morte é grande; mas cai quando dispositivo da nova lei torna a medida compulsória. publicado no $O$ Estado de São Paulo, São Paulo, 11 jan 1998. Disponível em: <URL: http://www.estadao.com.br/. [1998 jan 15].
} 
profissionais e, na perspectiva da terceira pessoa, desenvolvia um discurso pósconvencional, reclamando do Estado a imparcialidade do contrato social e os direitos das pessoas.

" (...) O novo ministro da Saúde, Carlos César de Albuquerque, terá que descascar um abacaxi logo depois de sua posse. Amadureceu em São Paulo uma proposta de tunga de fígados de cadáveres em benefício de meia dúzia de equipes médicas particulares, à custa dos cidadãos que morrem nas filas de espera de um transplante.

\section{(...)}

o Consenso da Hepatocracia é interessante. Cria um sistema pelo qual metade dos fígados vão para uma lista única, enquanto a outra metade deve ser rateada entre cinco instituições, todas públicas.

Seria uma beleza se não fosse uma mistificação. Três dessas instituições simplesmente não transplantam fígado, uma quarta faz dois transplantes por ano. E o que farão com os órgãos? Vão repassá-los a "hospitais associados".

E quem são esses hospitais? São as equipes privadas." FO$15 / 12 / 96$

O leitor que se congratula com a reportagem reafirma o papel de Estado como responsável em solucionar a questão.

"Espero, como muitos, providências imediatas por parte do Estado para que tamanhas aberrações acabem." FO- 22 FO$15 / 12 / 96 / 12 / 96$

Ainda tratando deste assunto o mesmo Elio Gaspari em agosto deste ano, relembra em "A volta dos caçadores de rins" (Anexo I, p. 158-159)

"Nesta semana realiza-se em Brasília um seminário organizado pela Associação Brasileira de Transplantes de Órgãos. Chama-se "Transplantes: aumentar o número para garantir qualidade". Tem tudo para oferecer boas sugestões, livrando a entidade da urucubaca que ela pegou em 1996, quando formulou uma proposta de privatização parcial dos órgãos a serem transplantados.

A questão é simples: as equipes privadas de transplantes de rins ( $R \$ 25$ mil) e de fígado ( $R \$ 40$ mil) nunca engoliram a fila única, na qual seus pacientes abonados ficam junto com a turma do SUS. Um dos temas do seminário será a participação de hospitais privados no processo de captação e de retirada de órgãos. Não há idéia melhor do que ver essas instituições ajudando a captação. Não há idéia pior do que vê-las associadas 
à idéia de se instituir uma taxa de captação. Coisa assim: para cada dois rins retirados por equipes privadas, um vai para a rede pública e a outra fica com os clientes particulares." FO- 13/08/00

Novamente ele denuncia a atitude utilitarista disfarçada destes profissionais na mesma avaliação de fala da reportagem anterior

"A maioria dos órgãos transplantados são retirados de jovens
acidentados ou baleados, que morrem em hospitais públicos. Os
grandes hospitais privados não atendem a choldra do SUS e não
lhes passa pela cabeça atender casos de trauma. Na hora em
que o motoqueiro arrebenta a cabeça num cruzamento de bairro
elegante, ninguém o leva para o hospital particular da região.
Instituída a taxa de captação, poderia acontecer a seguinte
gracinha: o jovem trabalhador acidenta-se a dois quarteirões do
hospital privado que para onde não pode ser levado. Vai para
uma instituição pública e tem morte cerebral. Numa
coincidência, chega a equipe de captação do hospital privado em
cujas cercanias ele se acidentou, tira-lhe os dois rins e leva um
consigo, para transplantá-lo num paciente da fila de particulares,
que é a dos doentes com algum dinheiro. Enquanto isso, um
outro doente, que nada tem além do SUS e está na fila pública
há mais tempo, continua lá." FO- 13/08/00

Nessa oportunidade a Associação Brasileira de Transplantes de Órgãos (ABTO) menciona de outra forma a sua participação no evento e termina colocando-se em fala pósconvencional, alegando o papel das instituições privadas inserido no mesmo contrato social e pelo mesmo ter iguais deveres e direitos dentro do sistema.

\begin{abstract}
"Oportunamente, teremos satisfação de transmitir ao jornalista os resultados do seminário, com certeza uma série de medidas eficazes que contribuirão para maior efetividade da política nacional de transplantes, desenvolvida pelo Ministério da Saúde e que conta com irrestrito apoio da ABTO. Como entidade séria e comprometida com o desenvolvimento dos transplantes no Brasil, a ABTO tem plena consciência de sua responsabilidade e do incômodo que esse compromisso pode causar, por contrariar interesses diversos." FO- 16/08/00
\end{abstract}

\title{
DISCURSO 2
}

No periodo de aprovação pelo Congresso Nacional da lei 9434/97 um leitor, após ler reportagem publicada pela FO escreve protestando (Anexo I, p. 147)

"(...) confesso que me indignei ante a satisfação com que a reportagem transmitiu esse feito. Tal medida fere os princípios individuais da cidadania." FO- 26/01/97 
Sua fala é baseada em princípios individuais de cidadania, nivel pós-convencional, estádio 5. Ele aplica para o exame desta nova norma uma regra baseada em princípios.

"Tal medida fere os princípios individuais da cidadania. Desrespeita a religiosidade individual de cada cidadão e macula o princípio de liberdade e democracia, que os políticos se vangloriam de haver conquistado." FO- 26/01/97

\section{DISCURSO 3}

No período que aguarda o sancionamento da lei pelo presidente Fernando Henrique Cardoso, diversos artigos e reportagens são publicados. Este é o momento em que se vive o clima polêmico com respeito ao caráter obrigatório da legislação e o articulista Hélio Schwartsman publica o artigo "Dos restos humanos", favorável a lei.

Elaborado em caráter egocêntrico, não discute a questão sob ponto de vista de princípios e justifica sua posição em argumentos do estádio 3, em uma ação de benevolência - é importante ser bom aos seus próprios olhos e aos dos outros. (Anexo I, p.

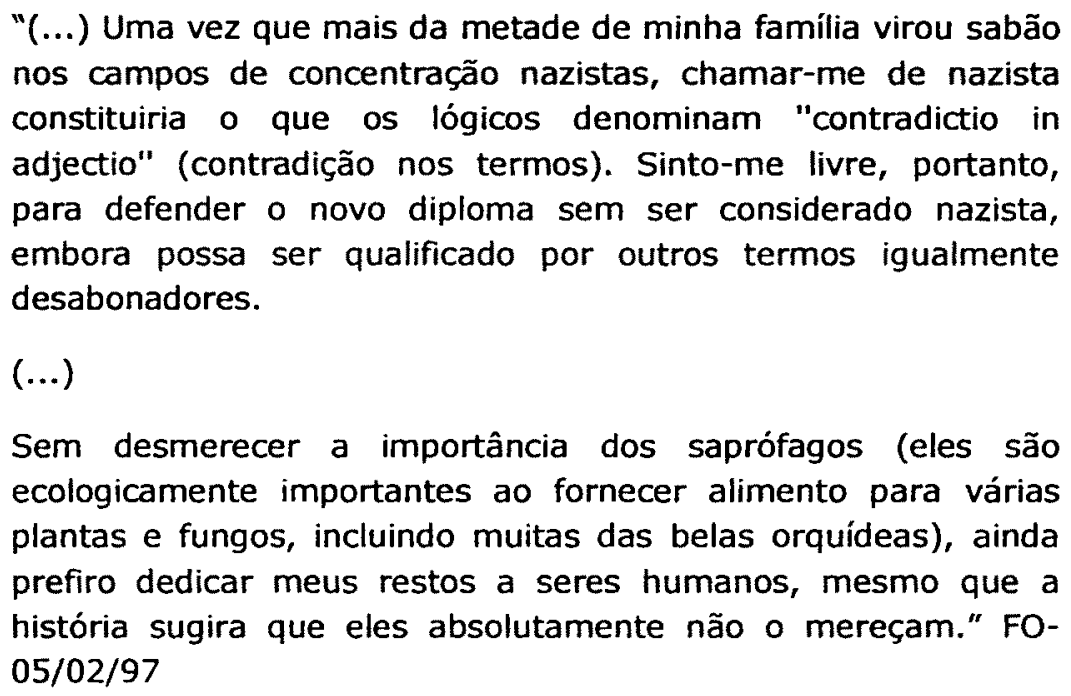

O leitor que conversa com ele argumenta em mesmo estádio mas, acrescenta uma conclusão de estádio 4 , por trazer a idéia de manter em funcionamento a instituição.

"(...) merecerem ou não nossos órgãos por atitudes inadequadas tomadas durante toda a sua história, sinceramente espero que essa lei dê certo, que funcione, que nós possamos nos sentir solidários até na hora da morte, mas jamais um produto de venda fácil." FO- 057/02/97 


\section{DISCURSO 4}

Ainda neste período, um leitor escreve carta criticando a posição do jornal em seu editorial "Para salvar vidas" mas falha em pretensão de validez ao definir a lei com autoritária. (Anexo I, p. 148-149)

"(...) depois o editorial aprovando essa lei absurda e autoritária sobre a doação de órgãos. Melhor seria se este jornal estimulasse um amplo debate com a sociedade sobre essas questões polêmicas, dando espaço à opinião pública, em vez de privilegiar a sua própria." FO- 15/02/97

No meu entender a carta também revela uma falha ao avaliar o editorial, pois na minha análise identifico que o ponto de vista do jornal expressa-se com base em alguns princípios e, portanto, atribuo o nível pós-convencional e não o convencional conferido pela carta. Destaco os parágrafos que evidenciam este aspecto

Sem dúvida, ainda existem problemas. É óbvio que providências são necessárias para coibir tanto o abjeto comércio de órgãos humanos como o abuso do poder econômico.

\section{(...)}

O argumento de que uma eventual omissão do morto poderia vir a contrariar a vontade de familiares é, em tese, válido, mas nada que não possa ser contemplado na futura regulamentação desse diploma legal.

É também importante que a manifestação de qualquer cidadão do seu desejo de não se tornar um doador seja feita da forma mais simples e desburocratizada possível, em nome da própria democracia no que tange às liberdades individuais.

Não nos resta dúvida de que a sanção da lei é um avanço. Entretanto, se a regulamentação não for cuidadosa e se não se mudar a mentalidade da sociedade brasileira, será apenas mais uma lei fadada a cair no ostracismo. Seria uma pena, pois estão em jogo vidas humanas. FO- 05/02/97

\section{DISCURSO 5}

Em primeiro de janeiro de 1998 entrou em vigor a lei do doador presumido. Eliane Catanhêde discute o assunto no artigo "Ano novo, vida nova". Favorável à lei, desenvolve argumentos de estádio 3 justificando a partir da regra de ouro. (Anexo I, p. 150-151) 
daquelas listas infindáveis de pessoas desesperadas, contabilizando o que resta da vida em meses, dias, às vezes horas, à espera de um rim, de um coração. Só no caso de rins, há cerca de 10 mil pacientes habilitados na fila. E nada. FO01/01/98

Um leitor discorda da articulista duvidando que todos apliquem a regra de ouro

\begin{abstract}
"Acho arriscado deixar a integridade física _neste caso, a própria vida_ das pessoas à mercê do baixíssimo nivel da ética praticada em nosso país. Imagine-se a angústia de alguém ao encontrar em um hospital o corpo de um parente, que tenha sofrido um acidente, 'depenado' sob a alegação de que teria ocorrido a tal 'morte cerebral'. Para quem acha que é exagero, lembre-se dos casos de sequestro de crianças e de mendigos, noticiados na Venezuela, para a retirada de córneas a ser vendidas para transplantes em Paris." FO- 08/01/98
\end{abstract}

A carta demonstra que o subscritor compreende a regra de ouro mas, pela sua resposta objetiva instrumental, a perspectiva de ação está no estádio 2 . Ela reconhece que as outras pessoas tem os seus interesses e, assim, existe um risco de alguém não seguir a regra por não ser este seu interesse imediato.

\title{
DISCURSO 6
}

Frente à rejeição pela população da obrigatoriedade imposta pela lei, diversas instituições médicas começaram a se pronunciar com respeito ao assunto, orientando a categoria que, ao arrepio da lei, somente tirassem órgãos de "pacientes" após a autorização da família. Isto é o que pode ser observado na reportagem "Família de doador decidirá transplante" e a expressão do consenso na carta de um leitor que cumprimenta o médico José Osmar Medina Pestana, diretor-clínico do Hospital São Paulo e presidente da Associação Brasileira de Transplante de Órgãos.

A fala utilizada pelo leitor é de nível convencional, estádio 3, pois o leitor tem um padrão de comportamento com perspectiva de seu papel social em conformidade à papéis a familia, e rejeita a conformidade da lei quando ela entra com estes deveres que querem preservar esta instituição.

"É inegável que a atitude corajosa, respeitosa, ética e correta vai livremente ao encontro das tradições brasileiras, na direção de respeito às famílias e dentro da mais elementar lógica." FO$03 / 01 / 98$ 


\title{
DISCURSO 7
}

Neste bloco, três correspondências fazem menção à um artigo de Elio Gaspari intitulado "Doutor Elias, o privatista dos tran\$plantes". O caso por ele denunciado implica a equipe de transplante do médico Elias David Neto e o fato de dois rins disponíveis para transplante serem ofertados, e não utilizados, à 33 hospitais públicos e privados pela Central de Transplantes da Secretaria da Saúde que coordena a lista de espera de órgãos.

Nessa ocasião, período das festas de natal e ano novo, nenhum deles tinha equipe de plantão para receber o órgão e submeter um transplante. A equipe que aceitou os órgão e executou o transplante foi a do Hospital Sírio Libanês, a mesma do Hospital das Clínicas da Faculdade de Medicina da Universidade de São Paulo (HC - FMUSP), que rejeitou o órgão por falta de plantonista. Caso isto não acontecesse, provavelmente os órgãos teriam sido perdidos mas, o que Gaspari quer difundir é o anacronismo da situação, pois houve, neste caso, um privilégio para quem pode pagar um serviço privado (Anexo I, p. 153-155)

\begin{abstract}
"À falta de interessados, os rins foram para o hospital Sírio Libanês e lá foram colocados em dois doentes de sua clínica particular de transplantes. Se isso não tivesse acontecido, os rins teriam se perdido.

Tendo acontecido, os pacientes receberam o que precisavam, e os médicos faturaram algo como $\mathrm{R} \$ 30$ mil por transplante.

Tudo nos conformes. Salvo num pequeno detalhe: o chefe da equipe de transplantes privados do hospital Sírio Libanês, doutor Elias David Neto, é também integrante da equipe de transplantes públicos do Hospital das Clinicas. O doutor tem dois empregos. Num, os transplantes valem até $R \$ 30$ mil. No outro, quem paga é o SUS, e a fatura rende apenas R $\$ 3$ mil. FO- 14/01/98
\end{abstract}

$\mathrm{O}$ argumento de Gaspari é de que para o Dr. Elias a linguagem está em estádio 5 , convencional e que, na ineficiência do contrato social estabelecido, emprega-se princípios de utilidade.

\footnotetext{
"No caso do doutor Elias, a inépcia do Estado e a eficácia do mercado coabitam na mesma pessoa. Maravilhosa sintese das virtudes privadas e das deficiências públicas. No dia em que o BNDES chegar a essa perfeição, o Brasil estará em outro mundo, talvez no Primeiro, talvez no outro." FO- 14/01/98
}

e conclui: se este é o princípio e o contrato está sendo rompido, devemos ressarcir os danos na mesma lógica deste estádio.

"Se tudo isso fosse pouco, há outro absurdo. Toda vez que uma equipe de médicos do sistema público de saúde capta órgãos de 
um cadáver, a patuléia do SUS paga $R \$ 2$ mil ao hospital que fez o serviço. Ou seja: a choldra pagou a retirada dos rins. Não havia plantonista nos hospitais públicos, e os rins foram para clientes privados da equipe do Sírio Libanês. Que tal devolver à ralé do SUS o dinheiro que ela pagou por dois rin\$ que acabaram privatizados?" FO- 14/01/98

Os leitores que conversam com este artigo fazem reflexões em estádios e níveis diversificados.

O primeiro discute na mesma lógica do argumento utilitário, estádio 5, desenvolvido no artigo.

"Quem leu o artigo, se não sabia, ficou sabendo no que vai dar a lei 'vampiro'. Para determinados médicos, foi a descoberta do mapa da mina: $R \$ 30$ mil pelo transplante de um rim. Enquanto aos trabalhadores, desempregados e miseráveis deste pais compete a obrigatoriedade de se transformar em meros fornecedores de matéria-prima para salvar a vida dos que dispõem de $R \$ 30$ mil." FO- 18/01/98

O segundo, também usa da lógica utilitarista mas, amplia a reflexão indagando como sustentar os direito, valores e contratos legais básicos de uma sociedade

"O mesmo SUS que se dispõe a pagar $R \$ 3$ mil pelo transplante, ou seja, dez vezes menos que o custo privado, repassa poucos centavos além de dois reais por uma consulta médica. O governo que divulga a nova lei dos transplantes é o mesmo que corta as verbas da saúde, 'remunera' aviltantemente os seus profissionais, não consegue levar a sério os programas de vacinação e o controle de epidemias. Qual a chance de os hospitais públicos, onde ora falta cama, ora faltam medicamentos básicos, recursos humanos competentes $\mathrm{e}$ dignamente remunerados, manter programas de transplantes? Doadores sempre existirão. O mesmo não se pode dizer com relação aos hospitais públicos. Senhores, não sejamos hipócritas! Creio que depois das sociedades gentílicas a coisa sempre funcionou assim: os menos favorecidos morrem para que os mais favorecidos vivam sempre assim, favorecidos. Em vida thes tiram a força de trabalho, a dignidade e a alma. Depois que morrem, como abutres, thes transplantam os órgãos." FO$22 / 01 / 98$

O último, à diferença dos anteriores, é uma mãe que teve dois filhos salvos por transplante executado pela equipe referida. Ela aduz, na perspectiva compartida do estádio 3, que o Dr. Elias é bom. Ela tem a necessidade de, em seu papel maternal de boa e amável, dever manter-se leal a ele e ter confiança em seus parceiros 
"Desde novembro convalesço de uma cirurgia por meio da qual doei um de meus rins para o meu filho mais velho, João Paulo, de dez anos. Há cinco meses, o meu marido também fez o mesmo: doou um de seus rins para nosso outro filho, Luís Eduardo, de oito anos. As duas cirurgias foram bem-sucedidas, graças à equipe do dr. Elias David-Neto _o mesmo que o articulista tenta espicaçar com criticas que considero injustas. Para viabilizar economicamente o tratamento dos meus filhos, o dr. Elias tirou-nos do privado e passou-nos para $o$ atendimento público; isto, ressalve-se, sem nunca ter perguntado se tínhamos ou não condições de pagar pelos transplantes. Por que será que ele deixou de ganhar trinta, ou melhor, sessenta mil reais_como Elio Gaspari citou em seu artigo_, para ganhar os três mil, ou melhor, os seis mil reais do SUS, já que se tratava de dois transplantes? Ele só fez isso para permitir que meus filhos sobrevivessem." FO- 25/01/98

A carta falha na pretensão de validade por erro de correção, pois a leitora compara uma situação de doação de órgãos intra-vivos com o de pessoas jả falecidas.

\title{
DISCURSO 8
}

A última análise para o ano de 1998 identifica um artigo de Jânio de Freitas, "Uma grande doação". Nele, existe uma argumentação, estádio 6, pós-convencional, com reflexões, baseadas em princípios que acusa não estarem salvaguardados os interesses e direitos na presença da imposição da doação presumida. Mas esta fala falha na pretensão de validez ao acusar de autoritário uma ação foi resultado de votação do Congresso Nacional (Anexo I, p. 155-156)

\begin{abstract}
"A lei da doação de órgãos já fez, ela mesma, uma doação de valor extraordinário: fez com que cada um, na multidão dos apáticos que compõem o Brasil de hoje, aprendesse na própria carne que está submetido pelo atual governo a um autoritarismo que não respeita os direitos da pessoa nem os direitos coletivos, pondo-se acima da lei e à margem da Constituição." FO$18 / 01 / 98$
\end{abstract}

Ele discursa ainda observando a posição do governo ao manter e sancionar a lei mesmo frente à ausência de um consenso social. $O$ pensamento baseado em principios éticos universais de estádio 6 de Jânio de Freitas, demonstra a dúvida quanto a pretensão de validez de princípios nela comprometidos e novamente argumenta sobre o comportamento autoritário do governo mantido em uma ação de estádio 2 - justiça dada em complementaridade de ordem e obediência. 
"Fusão de prepotência e má-fé é a exigência, sob risco de penalidades, de que os médicos se contaminem do autoritarismo fernandista e desrespeitem a recusa familiar à doação. Se houvesse o acesso fácil ao registro da escolha pessoal, nem seria exigido dos médicos o que não lhes compete, nem haveria motivo para intervenções familiares.

Mas prevaleceu o vicio de governar pelas ditatorialescas medidas provisórias e pela sujeição do Congresso com a arma da corrupção política. Muita gente, porém, começou a ver o que precisa ser visto para sua própria defesa." FO- 18/01/98

A carta que conversa com Jânio de Freitas é assinada por representante do Executivo que refere

"O presidente da República acatou a decisão do Congresso e sancionou a lei, por entender que ela representa uma esperança para os milhares de brasileiros na fila de transplante, apesar da controvérsia sobre a doação presumida." FO- 31/01/98

O que demonstra um estádio 4 de argumentação, pois apoia o bem estar de um grupo e a sua preservação estar independente de outros aí implicados. Aplicando as perspectivas de Selman nota-se que não vê o sistema de relações de perspectivas a partir de um observador, seu alcance é somente para perspectivas de relação eu-tu, segunda pessoa.

\section{DISCURSO 9}

Novamente em 2000 ocorre um incidente com órgão para transplante disponível e não utilizado. Josias de Souza em "Um pâncreas no lixo" relata o fato ocorrido no Hospital das Clínicas - FMUSP e acusa a burocracia, o descaso e nenhuma punição como causas para a perda de dois pâncreas. Sua narração somente indica a quebra na manutenção do sistema e inadequação no cumprimento de regras e na identificação de responsáveis, estádio 4, convencional. (Anexo I, p. 156-157)

"Só duas equipes médicas realizam esse tipo de transplante em São Paulo: uma do HC (Hospital das Clínicas) e outra da Beneficência Portuguesa. Ambas sofrem com a escassez de doadores.

Pois na noite da última quinta-feira um pâncreas pronto para ser transplantado foi parar na lata de lixo do HC. É o segundo pâncreas desperdiçado em menos de três meses. O outro foi para o lixo da Santa Casa de Misericórdia. Por trás dos dois episódios, há um roteiro em que se misturam muita burocracia, um certo descaso e nenhuma punição." FO- 04/06/00 
A carta que trata do assunto é uma resposta dos responsáveis do $\mathrm{HC}$ pelo caso. Sami Arap, vice-presidente da diretoria clínica do HC-FMUSP e presidente da Comissão de Transplante de Órgãos e Tecidos, e José D'Elia Filho, superintendente do HC-FMUSP, esclarecem os pontos levantados e concluem em fala, estádio 4 , convencional.

"A Unidade de Transplante de Rim da Divisão de Urologia do Hospital das Clínicas da Faculdade de Medicina da Universidade de São Paulo realizou neste ano 60 transplantes de rins e 5 de pâncreas, usando leitos em diversas áreas da instituição para atender a um maior número de doentes que aguardam na lista de candidatos da unidade e aproveitar totalmente os órgãos doados." FO- 09/06/00

Neste mesmo dia encontra-se uma resposta de Josias de Souza dizendo não ter sido o caso ainda esclarecido e sugerindo à administração do hospital justificar-se frente aos seus doentes pelo não cumprimento de suas regras, estádio 4 , convencional

"No documento, seis parágrafos de texto, o HC não explica por
que um pâncreas pronto para ser utilizado em transplante foi
parar no lixo. Tampouco informa que providências foram
adotadas para evitar que o episódio, reincidente, volte a se
repetir. Como a carta não nega uma única linha do que
publiquei, fica difícil entender a sua utilidade. Melhor seria se
oferecesse uma boa explicação aos doentes que esperam na fila
por um pâncreas." FO- 09/06/00

\section{DISCURSO 10}

O discurso interleitores a seguir guarda características bem diversas dos até o momento analisados, pois um representante da Divisão de Comunicação Social do Instituto Nacional de Câncer - Inca do Rio de Janeiro é quem dá uma orientação para uma leitora do estado do Paraná que pergunta a respeito do financiamento para transplantes de medula óssea. (Anexo I, p. 159)

\footnotetext{
"Por isso fiquei triste e revoltada ao saber que aquele hospital vai interromper os transplantes por falta de verba, fato que tem prejudicado até a compra de medicamentos para os doentes internados. O que têm a dizer a respeito do assunto os ministros da Saúde e da Educação e o presidente da República?" FO20/04/01
}

A leitora reclama do Estado o seu direito (estádio 5, pós-convencional) e o citado representante alerta que o sistema de captação de órgão bem organizado e cumprindo o seu 
dever, estádio 4, nível convencional. Na realidade ele está denunciando um discurso distorcido do Setor de Transplante de Medula Óssea do Hospital de Clínicas da Universidade Federal do Paraná.

\begin{abstract}
"Como o Brasil, desde 1999, conta com mecanismos alinhados com um sistema de cobrança e pagamento, tomou-se rotineiro e público o transplante de medula óssea no Brasil e dispensável a captação de recursos por outros mejos." FO- 02/05/01
\end{abstract}

\title{
DISCURSO 11
}

O neurocirurgião Raul Marino Jr., professor titular de Neurocirurgia da Divisão de Clínica Neurocirúrgica do HCFMUSP, assinou um artigo publicado em FO no espaço "Tendências e Debates" sob o título "O milagre dos transplantes". (Anexo I, p. 159-162)

Seu discurso transita desde questões cosmológicas transcendentais do nível préconvencional quando se refere à igreja e à profissão de médico

Essas são verdades duras, que todos prefeririamos ignorar, mas a medicina trouxe um lado sobre-humano e sublime à fealdade da morte, tornando-a nobre e generosa: o milagre das doações e o prodígio dos transplantes.

"O milagre dos transplantes foi-nos concedido neste século como um dom das modernas conquistas médicas e científicas. Ele surgiu como um dom do Criador a nós, pobres mortais, demonstrando que a medicina existe para o homem e não o homem para a medicina $e$, neste ponto, nossa medicina cruza com a filosofia moral, com uma nova ética e com uma renovada teologia, pois o médico só pode existir em razão de sua relação com o doente.

Os transplantes, ligados intimamente que estão ao ato supremo das doações, surgiram como que para testar nossas virtudes de solidariedade humana, nosso altruísmo, nossa generosidade, nossa piedade, nossa compaixão, nossa filantropia, nossa benevolência, nossa bondade, nosso amor ao próximo, nosso espirito humanitário, nossa indulgência, nossa excelência moral, nossa grandeza de alma, nossa misericórdia, nosso espírito de socorro, amparo e auxilio e, sobretudo, a virtude mais decantada nos Evangelhos: o amor e a caridade.

\section{$(\ldots)$}

Esse, a nosso ver, é o verdadeiro significado dos transplantes hoje: permitem que nós, pobres médicos, sejamos meros instrumentos tentando imitar o milagre da ressurreição, procurando _depois da morte_ continuar a oferecer a vida, 
revivendo a parábola: "Estava doente e cuidaram de mim!", pois somente $o$ ato heróico de sacrificar a própria vida por outrem irá nos proporcionar a verdadeira experiência de termos estado vivos."

até uma fala pós-convencional de estádio 5 ao relatar o papel do Estado dentro do contrato social
"Tem sido primoroso o trabalho das Organizações de Procura de Órgãos, que, desde 1997, são gerenciadas pela Secretaria de Saúde, junto com a criação da lista única de receptores, democratizando o sistema de doações. São dezenas de jovens enfermeiros e enfermeiras, orgulhosos de seu extenuante trabalho de correr os hospitais de todo o Estado à procura de potenciais doadores. É reconfortante e inspirador observar a tarefa desses jovens idealistas com as familias inconsoláveis, que acabaram de perder seus entes queridos. São eles que "ousam fazer aquela temida pergunta que ninguém gostaria de ouvir"."FO- 15/05/01

passando por uma fala de estádio 4 quando reclama a presença da mídia no cumprimento de seu papel institucional

\begin{abstract}
"Vemos a resistência e as recusas às doações elevarem-se até $60 \%$ depois de campanhas de esclarecimento ao público, como o famigerado "efeito Camila", propalado por uma simples novela, que despertou e motivou os doadores de medula. Milhares deixarão de morrer como consequência." FO- 15/05/01
\end{abstract}

e conclui na perspectiva egocêntrica, relação eu-tu, para designar a postura das pessoas contrárias à doação de órgãos.

"Há tempos vimos procurando um termo que definisse quem
procure impedir a realização de uma doação que salvará muitas
vidas e encontramos essa definição: um monstro! Seja ele
médico ou legislador." FO- 15/05/01

Foram duas as cartas que se comunicaram com este artigo. A primeira, de uma Fundação de crianças renais ressalta o aspecto pré-convencional por ele referido.
"Verdadeiramente, não há um ato de amor maior que doar um órgão àqueles que tanto sofrem, independentemente de nossas convicções religiosas." FO- 17/05/01

A segunda, assinada por um médico, elogia o artigo e destaca a espiritualidade nele transposto como prática não comum entre neurocirurgiões

$$
\begin{aligned}
& \text { "(...), jamais havia visto um neurocirurgião discorrer sobre } \\
& \text { espiritualidade como ele fez. Nós, médicos, e nossos pacientes }
\end{aligned}
$$


precisamos dessas palavras tão belas, proferidas por um expoente da neurocirurgia no país." FO- 17/05/01

A duas últimas carta deste bloco não foram aqui analisadas por tratarem de temas diversos à questão doação compulsória.

Não foram encontradas cartas para o jornal O Estado de São Paulo.

\section{a clonagem}

Por volta de 1997 e 1998 iniciaram-se as primeiras especulações sobre clonagem humana. Já em 1997 havia sido anunciada a primeira clonagem com animais - a ovelha escocesa Dolly, realizada por Rudolf Jaenisch e Ian Wilmut, pesquisadores do Instituto de Tecnologia de Massachusetts.

No Brasil, o primeiro clone animal somente virá a ser produzido no ano de 2001 e simultaneamente a geração de alguns transgênicos. Tanto a idéia de produção de novas espécies como reprodução das já existentes levanta indagações principalmente no meio religioso e científico e o receio de manipulação com vidas humanas. Em especial, discutese a diferenciação entre a clonagem reprodutiva e terapêutica: clonar embriões para desenvolver órgãos que poderão salvar vidas.

Um dos primeiros cientistas interessados em desenvolver pesquisas nesta área foi Richard Seed, um físico americano residente em Chicago. Mas em final de 2001 é anunciada a primeira clonagem humana realizada pela Advanced Cell Technology $(\mathrm{ACT})^{60}$. Neste mesmo período George Bush solicitava ao Senado americano aprovação de um projeto de lei proibindo a produção de cópias genéticas de seres humanos, seja para fins reprodutivos ou terapêuticos.

\section{Leitores e discursos}

Diante destes fatos históricos ocorridos no período investigado os leitores pouco se manifestaram na situação de diálogo com o jornal. A discussão se atém aos momentos de reflexão entre clonagem reprodutiva e terapêutica.

\footnotetext{
${ }^{60}$ ver reportagem sobre o assunto no Anexo I, p. 173-174.
} 


\title{
DISCURSO 1
}

Perante a notícia de que um cientista americano pretendia realizar a primeira clonagem humana, dois leitores conversam entre si. (Anexo I, p. 166-167)

$O$ primeiro alerta sobre os limites entre a ciência e a ambição do homem e as questões éticas e morais que podem envolver tal situação. Coloca-se como um observador de estádio 4, entende que existe um sistema organizado socialmente mas situa-se externo a ele quando refere que as pessoas que detêm o poder devem olhar para esta nova situação.

\begin{abstract}
"Com relação à clonagem, seria conveniente que as pessoas que detêm o poder e os destinos da humanidade se empenhem em discutir e analisar o que poderá ocorrer, caso esse louco e/ou outros 'clonadores' ponham em prática seus intentos. Poderemos ter o 'retorno' da Torre de Babel. Senhores cientistas do mundo, lembrem-se de que vocês são simples criaturas, com a permissão de prestar serviço à humanidade. A ética e a moral são fundamentais em suas funções." FO- 13/01/98
\end{abstract}

Perante a esta declaração um leitor discute a questão a partir de outro aspecto. Coloca a Ciência, o Estado e a Igreja como instituições autônomas. Sua fala denuncia uma passagem entre estádio 4 e 5 . Reconhece as instituições e refere que a forma de uso dos conhecimentos, a ação transgressora, é que pode causar danos. Ele transporta a responsabilidade para a ação do indivíduo

\footnotetext{
"Ela, em si, não viola a ética e a moral quando busca a ampliação do conhecimento. O elemento transgressor é o mau uso desses conhecimentos adquiridos por meio da ciência." FO$19 / 01 / 98$
}

\section{DISCURSO 2}

A próxima discussão somente acontece em 2001. Trata-se de um editorial da FO, "Os Limites da clonagem", que discorre a favor da clonagem terapêtica. Ele levanta as opiniões atuais sobre o tema: da comunidade cientifica, dos governos de alguns países e dos conservadores e conclui em posição favorável argumentado da importância da pesquisa médica orientada para salvar vidas. (Anexo I, p. 169-170)

"Os conservadores vêem na clonagem terapêutica uma forma de aborto, já que o embrião utilizado para fornecer as célulastronco acaba sendo descartado. Tecnicamente, porém, não há aborto, uma vez que o embrião nem chega a ser implantado em útero. $\mathrm{E}$ não faz nenhum sentido falar em aborto sem gravidez. 
A união do esperma com o óvulo fora do útero não é mais viva do que um óvulo isolado ou um átomo de carbono. A vaga semelhança com a noção de vida não deve impedir a pesquisa médica séria, com boas chances de salvar vidas de verdade." FO- 28/06/2001

O leitor que conversa com o jornal é o senador Tião Viana, relator da PL 90/99 que dispõe sobre reprodução assistida da autoria do senador Lúcio Alcântara. Ele relata sobre as dificuldades para a fundamentação do parecer e a busca de consenso e finda a explanação convocando a sociedade para o debate a fim de garantir princípios éticos universais, portanto ele se enquadra no nível pós-convencional, estádio 6.

"Considero, pois, fundamental que o Brasil acorde para esse
debate, cuja complexidade e cujo alcance merecem e exigem
que sejam estabelecidas, o quanto antes, as regras e os
mecanismos legais de fiscalização e de controle que coibam os
abusos por parte das empresas farmacêuticas e dos laboratórios
médico-científicos e garantam parâmetros éticos, morais e
científicos que resguardem a dignidade humana e seu patrimônio
genético. "FO- 03/07/01

Este senador volta a mandar correspondência, FO- 17/11/01, quando parabeniza o jornal pela qualidade de informação no trato das questões complexas aí envolvidas.

\section{DISCURSO 3}

Este discurso é resultante da objeção pública da Academia Nacional de Ciências dos EUA ao projeto do médico italiano Severino Antinori em clonar seres humanos. A reportagem mostra as contradições existentes sobre este tipo de clonagem. Sem entrar em qualquer outro mérito, seja ético, moral ou religioso, a matéria se atem às opiniões dadas sobre $o$ assunto pela comunidade científica e às posições de alguns países no encaminhamento desta questão. (Anexo I, p. 170-172)

Um leitor fez referência a uma fala apresentada por Antinori com relação ao número de candidatos inscritos no projeto.

\footnotetext{
"Antinori argumentou que, durante vários anos de trabalho em clínicas de fertilidade, desenvolveu métodos para identificar
}

\footnotetext{
${ }^{61}$ No momento a PLS 90/99 teve anexada a legislação citada nos pareceres da CCJ e CCS e está na SSCLSF - SUBSEC. COORDENAÇÃO LEGISLATIVA DO SENADO aguardando a leitura dos pareceres dos senadores Roberto Requião relator pela Comissão de Constituição, Justiça e Cidadania- CCJ e Tião Viana relator pela Comissão de Assuntos Sociais-CAS.
} 
embriões anormais. Ele diz ter mais de mil candidatos à clonagem." FO- 08/08/01

ao que ele responde em fala transcendental de estádio 3 , reagindo de forma unidirecional ao opinar sobre eles.

"(...), quão sábia terá sido a natureza ao fazê-los estéreis." FO09/08/01

\title{
DISCURSO 4
}

A FO publicou um artigo da professora Lygia da Veiga Pereira, do Departamento de Biologia do Instituto de Biociências da USP, "Clonar ou não clonar, eis a questão". O texto trata do diferencial clonagem reprodutiva e clonagem terapêutica, levantando a defesa da última devido às possibilidades em se salvar vidas a partir delas. A pesquisadora conclui em discurso pós-convencional, estádio 5 (Anexo I, p. 172-173)

\footnotetext{
"A proibição cega invariavelmente leva ao atraso da ciência e da melhora da qualidade de vida. Precisamos, sim, de legislação e vigilância, para introduzir o desenvolvimento das células-tronco embrionárias no Brasil sem ferir direitos nem deveres." FO$15 / 11 / 01$
}

Um leitor avança na reflexão e chama atenção para os aspectos dos princípios éticos universais, destacando o direito de igualdade.

\begin{abstract}
"O problema é que os sucessos da ciência e da tecnologia não estão à disposição de todos, e sim daqueles que detêm o poder politico e econômico. Seria ótimo se a clonagem fosse usada de acordo com os princípios éticos e a favor de todos os que precisam; afinal, há milhares de pessoas precisando de algum órgão para continuar vivendo. Sim à clonagem em favor da vida de todos, ricos e pobres. Não à clonagem só para quem tem dinheiro e poder." FO- 17/11/01
\end{abstract}

O levantamento do temas no banco de dados do Estado de São Paulo não acusou cartas de leitores sobre $\mathrm{o}$ assunto. 


\section{a dupla porta}

Dupla porta é o termo usado para hospitais do SUS que abriram uma segunda porta para atendimento também de pacientes particulares ou conveniados. Esta forma de atendimento deu início por volta de 1997 e desde então é assunto polêmico no meio da saúde. Isto decorre principalmente do receio de se passar a atender mais e com melhor qualidade casos particulares em detrimento dos pacientes que somente têm condições de recorrer ao sistema de saúde público.

Os hospitais que iniciaram este tipo de administração são os hospitais-escola ligados às faculdades de medicina. Dentre os que se inserem nesta característica está o Hospital das Clínicas, que passou a receber esta nova clientela no final de 1996, ocasião do término das obras de reforma que já previam áreas especiais para tal.

O tema, por suas características controversas, acabou gerando um projeto de lei do senado, o PL 449/99, do senador Lúcio Alcântara, que propõe alterar o art. 43 da lei n. ${ }^{\circ}$ 8080, de 19 de setembro de 1990 (Lei Orgânica da Saúde)

"Art. 43. A gratuidade das ações e serviços de saúde fica preservada nos serviços públicos contratados, ressalvando-se as cláusulas dos contratos ou convênios estabelecidos com as entidades privadas."

e assim, possibilitar aos hospitais universitários captar recursos provenientes de internações hospitalares. ${ }^{62}$

\section{Leitores e discursos}

O bloco a ser analisado guarda um traço distintivo, visto que, salvo um leitor, todos os signatários foram ou são representantes de instituições médicas. Ele tem início em 1999 com um diálogo entre os professores Adib Jatene e José Aristodemo Pinotti. Seguem três cartas decorrentes de um editorial da FO- 26/08/01 e o último diálogo se dá entre o já citado José Aristodemo Pinotti e representantes do Instituto Brasileiro de Defesa dos Médicos, Dentistas e Sociedade.

\section{DISCURSO 1}

José Aristodemo Pinotti envia carta ao "Painel do leitor" em resposta a um artigo publicado pelo Adib Jatene na qual ele faz referências às crítica de Pinotti ao atendimento

\footnotetext{
${ }^{62}$ este projeto ainda está em tramitação no Senado Federal e no momento está incluido em ordem do dia de
} 
diferenciado recém criado pelo HC-FMUSP. Este justifica-se dizendo que não é contra ao atendimento em dupla porta desde que seja feito em igualdade, ou seja reconhece o sistema mas desde que seja feito baseado em princípios de igualdade, é o conceito da imparcialidade dado pelo contrato, estádio 5, pós-convencional. (Anexo I, p. 175-176)

"Em nenhum momento afirmei isso; pelo contrário, deixei sempre claro que todos podem ser atendidos no HC. Porém com igualdade, com as mesmas esperas, pelos mesmos médicos, nos mesmos leitos e usando a mesma porta." FO- 13/05/99.

$\mathrm{O}$ único leitor leigo referido anteriormente, também faz referências a este artigo mas em discurso de estádio 4 , convencional - idéia de preservação do sistema social.

\begin{abstract}
"Oportuno e realista o artigo do ex-ministro Adib Jatene. O modelo do Incor não é o melhor nem o pior. É o único capaz de, nas atuais circunstâncias, situá-lo como uma ilha de excelência na rede pública. É também o caminho que terá de ser trilhado por santas casas e hospitais filantrópicos que desejarem manter a qualidade de seus serviços ou, pelo menos, sobreviver, diante da escassez de recursos públicos e da espantosa omissão das elites." FO- 13/05/99.
\end{abstract}

\title{
DISCURSO 2
}

Este diálogo apresenta três cartas comentando um editorial da FO que tratou da dupla porta. (Anexo I, p. 178-179)

O Editorial relata da tramitação do PL $449 / 99$ no Senado e aborda confrontando aspectos de justiça social e econômica

"Para os críticos da proposta, existe ai apropriação privada de recursos públicos. Numa visão talvez exagerada, a saúde pública apresenta graves deficiências, mas basta que uma instituição se destaque um pouco pela qualidade do atendimento, como normalmente se dá com os hospitais universitários, para pacientes ricos imediatamente se utilizarem de seus leitos, em detrimento dos pobres.

Embora caricatural, essa interpretação traz argumentos fortes. Já é difícil para o paciente pobre encontrar hospitais que atendam casos de maior complexidade. Se nos poucos que prestam o serviço ele ainda tem de disputar a vaga _e em condições adversas _ com o rico, cria-se uma formidável injustiça. Não raro, um cidadão humilde, mesmo recebendo o atendimento médico, morre à espera de uma vaga para cirurgia ou exame diagnóstico.

sessão deliberativa. 
Esse raciocínio só não é irretocável porque o sistema de dupla porta agrega qualidade ao hospital universitário. $O$ efeito mais óbvio é o financeiro. O Instituto do Coração, da USP, pioneiro na adoção da dupla porta, afirma que consegue, com os $25 \%$ de pacientes particulares ou conveniados, $60 \%$ de sua receita, enquanto o SUS, com $75 \%$ das vagas, responde por $40 \%$ do faturamento." FO- 26/08/01

Continua afirmando que a presença do usuário particular, mais exigente, acaba por melhorar a qualidade do mesmo e termina em reflexão para a busca de consenso "Evidentemente ofende o sentimento de justiça a idéia de que,
num mesmo hospital público, ricos e pobres recebam tratamento
diferenciado. A questão financeira, por outro lado, não pode
deixar de ser considerada. Ela, de alguma forma, pode trazer
benefícios significativos para a instituição e, portanto, para os
pacientes sem recursos. A questão é complexa e não deve ser
tratada com dogmatismo ou populismo, o que, infelizmente, não
tem sido a regra." Fo- $26 / 08 / 01$

Os três leitores que referenciam o editorial, concordam com ele. O primeiro, representante da associação Paulista de Medicina enquadra-se perfeitamente às razões do estádio 4 de que devemos manter em funcionamento a instituição com o cumprimento de obrigações de si próprio com a finalidade de contribuir para a sociedade.

\begin{abstract}
"Instituições que gozam de vários incentivos públicos (fiscais, equipamentos e recursos financeiros) para poderem atender ao SUS, propagam, através de altos custos, o atendimento via plano. Todos sabem que os planos de saúde, por terem uma regulamentação constantemente boicotada, padecem de males que nenhum ser humano deveria merecer. Nesse sentido agrega conflito, e não qualidade. Sob uma complacência estarrecedora, vemos recursos públicos alavancarem planos de saúde $e$ conflitos. Creio que toda a sociedade deva considerar inicialmente o que é uma digna e humana relação médicopaciente para então atingirmos a questão financeira. Quem sabe poderemos, assim, alcançar um Brasil de portas iguais para todos os diferentes." FO- 28/08/01
\end{abstract}

O seguinte sugere outras formas de gerar financiamento que não agridam os princípios éticos, aqui basicamente a igualdade.

"O dilema se baseia na crença de que a única forma de aumentar o orçamento dos hospitais_sem onerar o governo_é estabelecer uma dupla porta e vender, em hospitais públicos, serviços privados diferenciados. (...) 0 raciocinio de que o atendimento de pessoas diferenciadas no hospital público melhora o atendimento dos pacientes do SUS só será verdadeiro se todos forem atendidos de forma igualitária. Caso contrário, a tendência 
é piorar para os que não pagam, pois cria-se uma situação em que a excelência do hospital fica prioritariamente voltada para os que pagam, e os pobres vão ficando em guetos reservados ao ensino de graduação, à pesquisa e ao treinamento dos médicos mais jovens. É possivel e necessário colocar um pouco mais de recursos públicos nos hospitais universitários e reformular suas formas de gestão, incluindo o pagamento de salários dignos de forma aberta, justa e transparente." FO- 29/08/01

E o último focaliza a igualdade e a importância de se, na necessidade de dupla porta, renovar o comportamento da medicina para se compreender as novas situações no mesmo discurso de estádio 4

\footnotetext{
" Na medicina de hoje, com tantas opções, tantas escolhas, diferentes prioridades, decisões dificeis, a necessidade de um 'peer review' (revisão dos pares) de um comitê de conduta não é uma firula comportamental, mas uma necessidade imperiosa, sem a qual a dupla porta é uma 'porta sem saida'. Mas repito: parabéns à Folha por levantar assunto que não tem recebido a devida atenção das nossas entidades médicas." FO- 09/09/01
}

\section{o plano de saúde}

A necessidade de regulamentação dos planos de saúde perfaz todo o período da investigação. Criado à época da ditadura, exercia suas atividades sem nenhum controle externo. As empresas vendiam seus serviços com total liberdade, dessa maneira, decidiam sobre quais doenças, procedimentos e médicos o contratante teria direito ao assinar o contrato de assistência médico-hospitalar.

Com a lei 8078 de 11 de setembro de 1990, o Código de Defesa do Consumidor, o cidadão ganhou a possibilidade de defender os seus direitos e interesses como consumidor e, a partir daí, ocorrem avanços para a regulamentação desse setor. Assim, em 03 de junho de 1998 , foi criada a lei $9656 / 98$ que dispunha sobre os planos e seguros privados de assistência à saúde com a finalidade de proteger o usuário do plano de saúde e a polêmica medida provisória n. ${ }^{\circ} 2177-44$, de 24 de agosto de 2001, que trata sobre o mesmo assunto.

Neste periodo, em 28 de janeiro de 2000, foi criada a Agência Nacional de Saúde Suplementar (ANS) pela lei 9961/00, como órgão de regulação, normatização, controle e fiscalização das atividades que garantam a assistência suplementar à saúde favorecendo, dessa forma, os mecanismos de controle de intervenção nas empresas prestadoras de serviços. 
Mesmo assim, ainda se mantinham muitas inadequações contratuais e um número acentuado de queixas em órgãos de defesa do consumidor (Instituto Brasileiro de Defesa do Consumidor (IDEC) e Proteção do Consumidor - PROCON das Secretárias de Justiça e da Defesa da Cidadania). Como resultado disto, em 2001 foi reeditada a MP 2177-44 com a intenção de padronizar as coberturas fornecidas, impossibilitar a ruptura unilateral do contrato e regularizar o ressarcimento ao SUS, quando o usuário possuir também um plano de saúde.

\title{
Leitores e discursos ${ }^{63}$
}

Duas questões básicas são discutidas nesta seção: a dupla cobrança de usuários pelos hospitais conveniados, resultado das auditorias executadas pela CPI do INAMPS e a regulamentação sobre os planos de saúde durante a tramitação de seus retrospectivos projetos de lei.

Os envolvidos nos diálogos, na sua maioria, são representantes dos planos de saúde, representantes de instituições médicas, usuários dos serviços de assistência médica e representantes de órgãos de defesa dos consumidores.

\section{DISCURSO 1}

Este primeiro diálogo se dá entre o deputado Ayres da Cunha e a coordenadoraexecutiva do Idec Marilena Lazzarini. O deputado opinou sobre a interferência do governo nas empresas de saúde. Ele critica expondo posição contrária a este papel assumido pelo governo. (Anexo I, p. 180-181)

\begin{abstract}
"A notícia de que as empresas de saúde serão obrigadas a cumprir um plano padrão, que prevê a cobertura de partos e tratamentos de todas as doenças relacionadas no Código Internacional da Organização Mundial de Saúde, como Aids e câncer, é uma atitude despótica para um regime que se pretende democrático. Uma vez mais o governo resolve intervir para atrapalhar. E quem sai perdendo é o cidadão, que ficará sem opção: nem saúde pública nem saúde privada. Sabemos que o plano ideal seria aquele que pudesse cobrir todas as doenças, mas isso inviabiliza as empresas." FO- 18/05/96
\end{abstract}

\footnotetext{
${ }^{63}$ O discurso trata de reportagem sobre a aprovação de projeto de lei do deputado estadual Paulo Teixeira (PT) sobre os planos de saúde que obriga as empresas de medicina de grupo do Estado de São Paulo a dar cobertura a todas as patologias relacionadas ao Código Internacional de Doenças da Organização Mundial de Saúde (OMS) - lei 9495 de 05 de março de 1997; não teve análise porque a carta que se refere à ela não dialoga com o jornal (Anexo l, p. 184-185). Da mesma forma o dialogo entre Maria Inês Fornazaro e Luís Nassif (Anexo I, p. 191-192) que é um esclarecimento sobre reclamações junto ao PROCON de empresas de planos de saúde Medial Saúde. Outras cartas não foram analisadas por fugirem do tema central desta seção.
} 
Ele utiliza-se de um discurso pós-convencional que toma do contrato social e discute sobre a legislação em tramitação num cálculo racional de utilidade geral, estádio 5 .

\begin{abstract}
"Quando uma pessoa recorre a um plano de saúde privado, significa que fecha um contrato de acordo com o que tem condições de pagar. Os planos de saúde diferem entre si e as empresas também. Inclusive, existem diferentes planos dentro de uma mesma empresa. Cada um compra o que pode ou que melhor the convém pelo preço oferecido. Assim como um carro, um plano de saúde é um produto. Na linha Chevrolet, pode-se adquirir de Corsa a Omega. E, para cada modelo, há inúmeros opcionais, como ar-condicionado e toca-fitas. 0 mesmo acontece com planos de saúde, que têm preços diferentes para coberturas diferentes. Há pessoas que não têm o mínimo interesse em cobertura para gravidez, outras, em atendimento psiquiátrico ou Aids." FO- 18/05/96
\end{abstract}

Conclui demonstrando no mesmo estádio 5 que sente-se na condição de obedecer leis na caracterização de imparcialidade objetiva centrada no direito de liberdade

"Há grande preconceito contra as empresas de medicina privada, talvez porque o setor caminhe bem. Não nos opomos a uma regulamentação, em que cláusulas abusivas e injustas devem ser eliminadas. Mas não há necessidade de mais leis. Hoje as promotorias públicas e os Procons já fiscalizam os planos de saúde. O governo, em vez de dar conta da sua parte, prefere ficar redigindo propostas com o objetivo de se autopromover. 0 Brasil só se desenvolverá se for administrado com mais competência e menos interferência estatal." FO- 18/05/96

A carta discutindo o artigo inicia-se lamentando esta objetificação

"Ao ler o artigo do deputado Ayres da Cunha (18/5), afirmando que 'assim como um carro, plano de saúde é um produto', só nos resta lamentar." FO- 26/05/96

Lazzarini critica que o assunto tenha tratado a saúde sob o ponto de vista único e distanciado de um aspecto inerente a ela: a dignidade da pessoa humana (estádio 6, convencional) e assim sendo, a pessoa humana não ser um meio (produto) e sim um fim ( sua integridade fisica e psíquica).

"Desculpe-me, deputado, lembre-se que saúde não é automóvel: a prestação de serviços nessa área não pode ser examinada sem que se ponha em relevo a dignidade da pessoa humana, tendose em conta a preservação da sua integridade física e psíquica." FO- 26/05/96 


\section{DISCURSO 2}

As reportagens de que trata este discurso 2 denunciam a dupla cobrança de pacientes.

$\mathrm{Na}$ primeira, os repórteres fazem a denúncia atendo-se somente ao aspecto de que os hospitais mantêm uma prática comum de dupla cobrança de pacientes e que o SUS prescinde de controlar (reconhece o sistema, suas regras e papéis - estádio 4, convencional). Em nenhum momento existem referências quanto às implicações éticas envolvidas neste procedimento consabido, somente demonstra a situação em seu aspecto de interesses partilhados entre instituições que ignoram direitos individuais das pessoas (estádio3, convencional). (Anexo I, p. 181)

"Segundo a Folha apurou, é prática comum em parte dos 6.200 hospitais conveniados ao SUS cobrar duas vezes por uma consulta quando o paciente tem algum tipo de plano de saúde privado.

(...)

Essa prática foi relatada à Folha por funcionários do SUS na condição de não terem seus nomes revelados. Esses funcionários estão insatisfeitos com a decisão do Ministério da Saúde de não atacar essa perda de dinheiro indevida.

(...)

A fiscalização direta nesses 200 hospitais já permitira reduzir quase a $50 \%$ a cobrança em dobro.

Essa fiscalização, entretanto, poderia contrariar os empresários do setor. Consequentemente, muitos hospitais poderiam pedir descredenciamento do SUS. E isso causaria um colapso no sistema de saúde pública do país.

Os hospitais usam a cobrança dupla por considerarem baixa a remuneração do SUS e dos planos de saúde em geral." FO$24 / 07 / 96$

As perspectivas propostas por Selman nesta relação Estado X hospitais, ajustam-se perfeitamente ao nível 2 , pois se comporta da mesma maneira da criança ao reconhecer a distinção entre aparência externa-realidade interna, ou seja, que os próprios podem iludir os outros quanto aos seus estados internos: dois indivíduos particulares vendo a si mesmo mas não no sistema de relações entre eles. 
A partir deste transitar estádio $2 / 3$ da reportagem o representante do Sindicato dos Hospitais e Santas Casa de Estado de São Paulo (Sindhosp) escreve para o jornal em discurso eu-tu criticando um "denuncismo inconseqüente" e conclui

\begin{abstract}
"Esperamos que a Folha venha a público dizer quem são os fraudadores para que estes possam ser punidos, garantindo-se, assim, mais recursos para o atendimento da população mais necessitada e preservando a imagem das instituições privadas que trabalham honestamente neste país." FO-27/07/96
\end{abstract}

Identificamos uma fala que, de uma perspectiva individual, aplica a regra de ouro como justiça adjetivada de benevolente "(...) atendimento da população mais necessitada" numa perspectiva de segunda pessoa, auto-reflexiva, que reconhece certos valores da relação.

Uma semana depois a FO publica nova reportagem sobre o tema e novamente ocorre o diálogo entre o jornal e o representante do Sindhosp, esta se mantém no mesmo nível convencional e do qual destaco os seguintes trechos (Anexo I, p. 182-183)

"Relatório de auditoria realizada pela Procuradoria da República em São Paulo informa que o dinheiro público destinado à saúde é gasto de forma irregular em hospitais de São Paulo (...)Os diretores do Incor afirmam que não há nenhuma irregularidade. "O relatório deixa claro que nenhum dinheiro foi desviado, levado para casa", afirma Anadyr Marcondes, presidente da Fundação Zerbini, ligada ao Incor."

\title{
(...)
}

Tudo começou com a CPI (Comissão Parlamentar de Inquérito) do Inamps, que finalizou seus trabalhos em 94. Os resultados foram enviados às procuradorias da República em todos os Estados. Agora começam a aparecer as conclusões das investigações locais.

\section{(...)}

Ainda é desconhecido o valor total das irregularidades no país. Segundo a Folha apurou, ele pode superar $R \$ 2$ bilhões ao longo de um ano em todo o país.

Esse valor equivale, aproximadamente, à metade do que o governo pretende arrecadar com a CPMF, o imposto do cheque, aprovado no mês passado. Jatene argumenta que a CPMF é indispensável para solucionar a crise na saúde pública. 
Se inexistissem esses desperdicios no nivel em que foram detectados e se houvesse um controle rigido ou vontade política de fiscalizar a boa aplicação dos recursos da saúde, certamente haveria uma prestação de serviços e ações de saúde muito mais eficientes", afirmam os procuradores Consuelo Yatsuda Moromizato Yoshida e Januário Paludo no relatório." FO$02 / 08 / 96$

Percebe-se que existe uma intencionalidade na reportagem em demonstrar que se houvesse controle sobre o sistema de saúde não seria necessário a cobrança da Contribuição Provisória sobre Movimentação ou Transmissão de Valores e de Créditos e Direitos de Natureza Financeira - CPMF.

A carta resposta não atenta para a questão da CPMF e somente permanece no discurso eu-tu, sublinhado pela relação de autoridade de estádio 2 e que responde a um juízo externamente admitido - eu me comportei e não posso ser castigado.

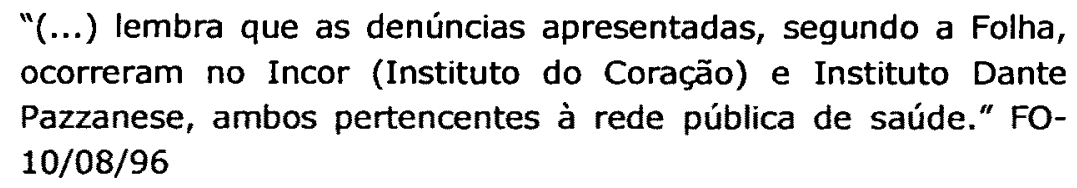

Ao final, reclama a ausência de justificativa da FO com respeito a acusação feita aos hospitais conveniados

"Resposta dos jornalistas Fernando Rodrigues e Paulo Silva Pinto _ O Ministério da Saúde sabe quais são os hospitais fraudadores. Cabe ao órgão tomar as providências." FO- 10/08/96

A atitude dos repórteres também está enquadrada em estádio 2 e eles referem não ser a autoridade para retirar a sanção (externalidade de papel dentro do contexto social, reconheço os interesses dentro do sistema mas coloco-me em posição individualista concreta).

\section{DISCURSO 3}

Uma pequena nota da coluna de Joyce Pascowitch gera o discurso ora apresentado (Anexo I, p. 185-186)

"Cruz vermelha

Experts no tema garantem que a confusão em torno dos planos de saúde pode ganhar capítulo extra. 
A avaliação é que o rompimento da Amil com o hospital Santa Catarina pode ter efeito dominó. Ou seja, outros hospitais de peso estariam para romper com outras empresas do tipo." FO$15 / 07 / 97$

$\mathrm{O}$ leitor que toma desta informação reconhece que as pessoas têm valores $\mathrm{e}$ interesses diferentes em relação ao seu grupo (médicos e usuários) e que existe um contrato social a ser obedecido: o cálculo racional de utilidade não é correto, pois o médico é explorado e o usuário punido, ou seja, ele vislumbra "o maior bem" somente para os donos dos planos privados (estádio 5 , pós-convencional).

"As decisões estão sendo tomadas pelo corpo clínico de cada
hospital e têm total apoio da Associação Paulista de Medicina.
Não podemos mais admitir a conduta de planos privados de
saúde que exploram os médicos e punem os usuários em nome
do lucro." FO- $20 / 07 / 97$

\section{DISCURSO 4}

Um leitor conversa com um artigo publicado e assinado pelo presidente da Federação Nacional das Empresas de Seguros Privados e de Capitalização (Fenaseg) João Elísio Ferraz de Campos. (Anexo I, p. 189-190)

Ferraz faz um discurso estádio 5, pós-convencional, de que leis e deveres devem ser baseados em cálculo racional de utilidade geral concluindo

"Hoje, os planos mais completos oferecidos pelas seguradoras custam, em média, R\$ 100. Outros planos, mais limitados, variam de $R \$ 30$ a $R \$ 50$. Se o Congresso, no entanto, obrigar a sociedade a consumir apenas planos completos, com certeza os usuários de planos menos abrangentes sofrerão aumentos de até $100 \%$. Não vamos nos iludir com isso.

Também não se compreende a resistência de alguns setores à participação do capital estrangeiro. Vale lembrar que, no caso da saúde, trata-se de capital de risco e de natureza nãoespeculativa. Do nosso ponto de vista, essa concorrência é bemvinda e saudável, e o consumidor só terá a ganhar com ela. 0 que esperamos é que o Senado, responsável pela manutenção do equilibrio do pais, tenha o cuidado de evitar que o Sistema Único de Saúde seja sufocado pelo retorno de cidadãos que, no passado, ao optar por coberturas privadas, desoneraram 0 Estado. "FO- 22/04/98

A leitora responde também em fala pós-convencional, estádio 5, atendo-se ao aspecto de que não se deve colocar as pessoas como meio dentro da relação meio fim. 
"Não são 'os seguros-saúde que oferecem um cardápio', como o senhor diz. Há erro no sujeito e na forma verbal: nós, cidadãos em geral, somos oferecidos como cardápio para os planos de saúde." FO- 09/05/98

\section{DISCURSO 5}

No período da votação da lei $9656 / 98$ o jornalista Luís Nassif publica um artigo criticando a lei com uma observação pontuada sobre o parecer dado pelo relator da Comissão de Assuntos Sociais, Sebastião Rocha (PT-AP) (Anexo I, p. 190-192)

"2) Ai vem o nobre senador Sebastião Rocha e diz o seguinte: vocês vão ter de pagar por uma série adicional de procedimentos, que não constava de seu plano original. 0 consumidor não necessitaria, já que não pertence a nenhum grupo de risco. Mas é obrigado a aceitar a conta. Se esses procedimentos onerosos ampliarem as despesas para 600, as seguradoras acrescentam mais $15 \%$ e o custo do plano salta para 690 . Nesse exemplo, há um aumento de $20 \%$ para todos os segurados, por conta do presente do senador Rocha." FO$14 / 05 / 98$

Nassif faz uma análise com argumento de estádio 5, pós-convencional discutindo a lei versus cálculo de utilidade geral. Nesse ponto, ele mostra o erro do relator que resulta na discrepância entre o bem e o valor que a norma vai gerar.

$O$ relator responde afirmando que cumpriu o seu papel e que tanto a comissão como o senado aprovou por consenso o projeto lei. Sua resposta transita entre o estádio 5 e 6 . Ele, ao mesmo tempo que reconhece o contrato social protegendo os seus direitos e os dos outros, agrega a observância da utilidade como critério de elaboração de uma lei ao reconhecer que princípios éticos universais devem também pautar este processo.

\footnotetext{
"Apesar das limitações regimentais impostas à relatoria, creio que a proposta por mim apresentada levou em conta, sobretudo, o fato de a matéria envolver um bem inalienável _a própria vida humana. O projeto foi aprovado por consenso na Comissão de Assuntos Sociais e no plenário do Senado. Os aprimoramentos foram feitos com zelo e reflexão. Pelo menos cumpri com a minha obrigação. As mudanças no Senado foram poucas, mas importantes, garantindo melhor equilíbrio entre as necessidades dos usuários e o mercado. A existência de uma lei, embora não seja a esperada por todos nós, tira os consumidores da condição de reféns, repetidamente lesados na selvajaria que impera no setor de planos e seguros de saúde no pais." FO- 22/05/98
} 


\title{
DISCURSO 6
}

A correspondência desta seção revela um artigo de um advogado que falha por pretensão de validez ao argumentar a favor dos planos de saúde (Anexo I, p. 195-196)

\begin{abstract}
"Ao exigir que o Hospital das Clínicas e seus institutos deixem de atender de forma diferenciada os titulares de planos de saúde conveniados, os promotores paulistas estão prestando um enorme desserviço ao país, condenando-nos a continuar vivendo dentro de um palco dantesco, em que os círculos do inferno permanecem reservados aos mais pobres. Ainda não thes caiu a ficha: são os planos de saúde privados que mantêm o Hospital das Clínicas e os seus institutos em condições operacionais, remunerando-Ihes os serviços de forma correta e permitindothes atender os milhares de abandonados da sorte, que diariamente procuram os seus serviços gratuitos, sendo invariavelmente atendidos dentro de padrões muito superiores aos da imensa maioria dos hospitais brasileiros. Fosse o complexo hospitalar da Universidade de São Paulo depender dos repasses do SUS, com certeza sua capacidade de atuação seria outra, bem mais parecida com a lastimável realidade apontada pela consultoria inglesa.
\end{abstract}

\section{(...)}

A razão para isso é simples: do jeito que está a saúde pública brasileira, e com as novas regras, a sensação que se tem é que o governo está querendo transferir o mico para os planos privados, deixando a seu cargo bancar o prejuízo de um sistema falido _e que não tem cura enquanto não for mudada boa parte das práticas adotadas." FO- 09/06/99

O leitor, baseado-se em dados publicados na FO, inverte o discurso e em fala pósconvencional (orientação por princípios éticos), denuncia o Hospital das Clínicas em favorecer os convênios com a "segunda porta" transgredindo a igualdade de direitos.

"O articulista tem a coragem de afirmar, criticando os promotores públicos: 'Ainda não thes caiu a ficha: são os planos de saúde privados que mantêm o Hospital das Clínicas'. É demais! Cálculos publicados também na Folha pelo professor José Aristodemo Pinotti demonstram que em 1997, quarto ano da 'segunda porta', os recursos que entraram pelos convênios significaram somente $1,2 \%$ do orçamento do Hospital das Clínicas, somados os recursos do Tesouro e do SUS. Portanto, o que ocorre é exatamente o contrário: é o Hospital das Clínicas, com dinheiro público, que ajuda a aumentar o lucro dos convênios, usando, para isso, o absurdo ético da 'segunda porta'." FO- 14/07/99 


\section{DISCURSO 7}

Este discurso 7 é um exemplo do agir comunicativo em busca de consenso. Um editorial da FO mostra como, ao existir dúvida quanto a pretensão de validez da MP 217744 grupos organizados puderam indicar falhas quanto verdade, correção e sinceridade. (Anexo I, p. 198)

"A nova versão da medida provisória que regula os planos de saúde obteve uma rara unanimidade. Ela conseguiu o repúdio veemente e conjunto de Ordem dos Advogados do Brasil, Conselho Federal de Medicina, Associação Médica Brasileira, Fundação Procon, Instituto Brasileiro de Defesa do Consumidor, Fórum de Entidades Nacionais dos Portadores de Patologias e Deficiências e Fórum Nacional de Acompanhamento da Regulamentação de Planos de Saúde, entre outros.

Os motivos para a rejeição são simples e eloquentes. 0 comunicado conjunto das entidades não poderia ser mais direto: "A Agência Nacional de Saúde Suplementar (ANS) engana a população e afronta o Congresso ao fazer editar medidas tão arbitrárias e lesivas aos usuários." FO- 15/08/01

A carta que trata deste editorial faz reflexões sobre a importância da participação do cidadão nesses processos, enquadrando-se no estádio 6, pós-convencional: enquanto pessoas racionais, percebemos a validade dos princípios e comprometemo-nos mutuamente com eles. 


\section{DISCUSSÃO}

A análise das falas consideradas neste trabalho não prescinde de uma observação essencial. Os relatos recolhidos devem ser considerados dentro de um espaço público delimitado - mídia jornalística: jornais Folha de São Paulo e O Estado de São Paulo, e os sujeitos da comunicação - leitores dos jornais: um grupamento alfabetizado da população, com escolaridade de nível médio e superior e predomínio das classes sociais A e B.

Os diálogos apresentados também pressupõem uma universalidade da racionalidade comunicativa dada pelos conceitos de verdade, correção e sinceridade para o reconhecimento de uma pretensão de validade. Observa-se o ato de fala (artigo ou carta) em um primeiro momento quanto a sua pretensão de validez - o leitor que pretendia validade de sua fala enviou uma correspondência para o jornal tencionando estabelecê-la discursivamente.

Concomitantemente, nem todas as cartas estudadas guardaram situações de fala identificadas no processo comunicativo determinado para este trabalho: interlocutores identificados à semelhança do discurso falado. Na coleta dos bancos de dados diversas cartas expressaram algum tipo de argumentação sobre os temas tratados. Suas origens retratam uma pluralidade de meios, seja da mídia ${ }^{64}$ ou das conversas e diálogos públicos e privados, que ao apresentarem uma pretensão de validez, levou o leitor a expor a sua opinião no jornal. Isto impediu o seu aproveitamento na pesquisa por risco de compromisso do controle de pretensão de validade, dada a impossibilidade de avaliação se o que é dito confere com a fala ou fato desencadeante. Conforme ressalta Habermas,

"O importante é saber que podemos ler a estrutura dos pensamentos observando as estruturas de proposições; e as estruturas de proposições são as partes elementares de uma linguagem gramatical, passiveis de verdade. Dependemos, pois, do medium da linguagem quando queremos explicar a diferença entre os pensamentos e as representações" (HABERMAS 1997a, p. 28).

\footnotetext{
${ }^{64}$ o termo mídia envolve rádio, o cinema, a televisão, a escrita impressa em jornais, livros, revistas, boletins e os meios eletrônicos.
} 
Aqui vale lembrar que a interpretação também coloca o observador como um ator envolvido nas negociações sobre o sentido e a validez da análise, ao mesmo tempo que não pode supor que a sua contextualização parta de iguais suposições e práticas.

"Ou seja, ele é obrigado a empreender idealizações, por exemplo, a atribuir significado idêntico a enunciados, a levantar uma pretensão de validade em relação aos proferimentos e a considerar os destinatários imputáveis, isto é, autônomos e verazes consigo mesmos e com os outros" (HABERMAS 1997a, p. 20).

Mas é o quadro de estádios de interação, perspectivas sociais e estádios morais que estabelece uma forma confiável de medida destas comunicações interleitores ou leitores versus jornais.

A leitura horizontal dos diálogos indica comportamentos significativos tanto inter temas quanto por diálogos dentro do período analisado. A diferença associada aos leitores de cada jornal decorre da forma de apresentação dos assuntos por cada um deles. Também, temporalmente, existe uma tendência em variar o número de conversações conforme a qualidade do fator desencadeante.

Da mesma maneira, abordar alguns dos temas como pôde ser observado para drogas, aborto e doação de órgãos à diferença de planos de saúde, eutanásia, clonagem e dupla porta levaram os leitores a se posicionar em forma diversificada. A distinção se dá na situação de discurso criada apresentar uma característica básica: o rompimento de uma tradição por meio de uma proposta de uma nova norma regulamentadora. Isto aponta a forma de compreensão do mundo da vida racionalizado na sua diferenciação estrutural que toma as três dimensões aí envolvidas: a cultura, a sociedade e a personalidade.

"En lo que respecta a la cultura y a la sociedad, la diferenciación estructural se pone de manifesto en un cresciente desacoplamiento entre sistema institucional e imágenes del mundo; en lo que atãne a la personalidad y la sociedad, en la ampliación del espacio de contingência en el establecimento de relaciones interpersonales, y en lo que se refire a la cultura $y$ a la personalidad, esa diferenciación estructural se manifesta en que la renovación de tradiciones depende cada vez en mayor grado de la 
disponibilidad a la crítica y de la capacidad innovadora de los individuos" (HABERMAS 1988b, p. 207). ${ }^{65}$

Outro aspecto diz respeito aos diálogos falhos na pretensão de validez. Situações emotivas, principalmente associadas aos temas com implicações religiosas, induziram a maior erro da pretensão de validade ${ }^{66} \mathrm{O}$ uso de ironias e a decorrente quebra da sinceridade impede o entendimento em algumas situações comunicacionais. Estes exemplos impedem qualquer possibilidade de consenso. Não é por menos que Habermas coloca a sinceridade como uma das condições para viabilizar a reflexão dos agentes. Quando cada um leva o outro a ser reflexivo e crítico força a si mesmo também a manter um comportamento auto-reflexivo e crítico, pois só assim ele poderá reconsiderar e até mudar suas interpretações.

\section{o aborto}

Tomando-se do tema aborto pode-se observar como os sujeitos de ação se mantêm sustentados no contexto de um mundo da vida e dele retiram os seus recursos argumentativos. Existe um momento "forte" de pressão cultural e social que perfaz quase todo o período com respeito a tramitação de projetos que pretendem mudar a legislação referente ao aborto.

No discurso institucional temos, por um lado, argumentos dos representantes da Igreja, do judiciário, do legislativo e do executivo contra as normas que possam vir a viabilizar situações de aborto. Por outro, representantes do legislativo, do executivo e judiciário favoráveis, seja à descriminalização, seja à legalização. Intermediando as conversações institucionalizadas interferem outros leitores que não apresentam identificações especiais. ${ }^{67}$

\footnotetext{
${ }^{65}$ Habermas denomina cultura: o acervo de saber em que os participantes da comunicação se abastecem de interpretações para entender-se sobre algo no mundo; sociedade: as ordenações legitimas através das quais os participantes na interação regulam seus lugares nos grupos sociais, assegurando com isso a solidariedade e personalidade: as competências que convertem os sujeitos capazes de linguagem e de ação, isto é, os capacitam para tomar parte em processos de entendimento e para afirmar neles a sua própria identidade (Cf. HABERMAS 1988b, p. 207)

${ }^{66}$ Isto pode ser conferido nos discursos $1,2,4,8,13$ e 14 na seção "o aborto" e nos 4, 7, 8 da seção a doação de órgãos.

${ }^{67}$ Isto pode ser conferido nos discursos 1, 2, 6, 8, 13 e 14 da seção "o aborto".
} 
As argumentações contrárias pretendem assegurar a validez social das normas positivas vigentes. Utilizam, de uma maneira geral, formulações na primeira pessoa que expressam preferências subjetivas, aqui imperativos, na intenção de levar os agentes a um determinado comportamento, ou seja, eles prescrevem ao ouvinte uma escolha de princípios: o aborto fere o direito à vida e os mandamentos da igreja católica.

Mesmo nas situações em que os sujeitos contrários posicionaram-se como observadores, manteve-se a atitude em descrever as funções cabiveis às proposições e sentimentos do ponto de vista interno dos falantes - eles já exprimem a escolha de princípios que em última análise determina a forma de vida, usam de um agir estratégico para manter um comportamento.

Por outro lado, as proposições originam-se em função de um agir comunicativo um é motivado pelo outro para uma ação em busca do digno reconhecimento da norma. Neste caso, os falantes levantam princípios universais que levam um sujeito a aduzir prós e contras durante uma argumentação.

Enquanto os primeiros se caracterizam em definir qual argumento aceitar, os outros provocam a argumentação necessária à discussão da pretensão de validez levantada e a maneira que, a partir de uma base de validez da comunicação voltada para o entendimento, move o sujeito a aceitar ou não a sua oferta.

Os níveis de desenvolvimento não se mostram como provocadores de interlocução, mas influenciam a qualidade de respostas encontradas. $\dot{A}$ exemplo, as recomendações da Igreja consistentes aos princípios nela inerentes e, pelo tal, são sinceras, geradoras dos comportamentos assimétricos entre falante e destinatário e que levam a reciprocidade e auto-reflexividade. Assim analisemos como se comportam os outros leitores.

Os leitores favoráveis ao aborto mantêm respostas $\mathrm{em}$ perspectiva social egocêntrica no discurso eu-tu. A razão para este comportamento não moveu os leitores para a aceitação da recomendação do princípio e simplesmente refletiu uma exposição de sentimentos por parte deles. Isto porque existe uma conexão interna entre a autoridade de um mandato e a obrigação de um destinatário fazer ou não o que é recomendado e a indignação de quem não se sente obrigado é a resposta afetiva dada porque a pretensão de validez não confere aos representantes da Igreja a dignidade de uma autoridade moral. ${ }^{68}$

\footnotetext{
${ }^{68}$ Isto pode ser conferido no discurso 2 da seção "o aborto".
} 
Ao contrário, os leitores discordantes às falas institucionais favoráveis mostraram um comportamento de resposta diferenciado e transitaram para o nivel convencional de um observador. Eles conferem a autoridade moral da Igreja e pelo tal conseguem ocupar o lugar de um observador e auto justificar a aceitação da norma a partir de argumento que transparece o reconhecimento de seu lugar no grupo, ou seja, mobilizam-se pelo discurso religioso a aceitar esta situação como uma imposição duradoura. Isto não provoca qualquer argumentação de estádio 5 ou 6 pois não existem outros princípios, a não ser os religiosos como força de argumentação. ${ }^{69}$

De todos os discursos de representantes da Igreja somente um difere e provoca um comportamento diferente nesse conjunto. O padre Lodi, pela sua posição radicalizada dentro da Igreja, gera a partir de seu rigorismo moral uma não reflexibilidade e flexibilidade do diálogo. Sua argumentação trabalha em agir estratégico para manter um comportamento desejado e não transparece um agir comunicativo que motive o outro a uma ação de adesão.

A resposta dos leitores frente a esta atitude sectária resultou em comportamentos por um lado agressivos (leitora Bartira) e por outro "desesperados" (leitora favorável a ação do padre). Esta última, na crença de seus princípios religiosos, buscou por qualquer argumento para justificá-lo: inverte a relação meio/fim ao concordar com a estratégia de expor a criança para obter a rejeição da norma pelo Congresso Nacional. Isto pode ser explicado pela interação ter sido dada não em função do outro mas na autoridade - a força do sagrado, ou seja, na objetividade da norma. ${ }^{70}$

"O fascínio despertado por instituições detentoras do poder, que ao mesmo tempo atrai e repele, revela a fusão de dois momentos aparentemente incompativeis. A ameaça de um poder vingador e a força de convicções aglutinadoras não somente coexistem, como também nascem da mesma força mística" (HABERMAS 1997 a, p. 43).

$\mathrm{Na}$ observação dos representantes do judiciário sobressai dois pontos a serem discutidos: o primeiro indica a tendência de "o judiciário falar com o judiciário" e o segundo reflete, por parte dos representantes do judiciário contra o aborto, argumentações

\footnotetext{
${ }^{69}$ Isto pode ser conferido no discurso 2 da seção "o aborto".

${ }^{70}$ Isto pode ser conferido nos discursos 4 e 9 da seção "o aborto".
} 
baseadas exclusivamente no direito positivado. Estas tendências podem ser explicadas tanto pela proximidade da idéia do sagrado para a magistratura. ${ }^{71}$

"Em sociedades organizadas em forma de estado, a ordem normativa natural é reformulada em normas do direito. Entretanto, em sociedades tradicionais, o próprio direito ainda se alimenta da força do sagrado religiosamente sublimado. Na fusão sacral entre facticidade e validade se enraíza por exemplo, a hierarquia das leis, da tradição jurídica européia, segundo a qual o direito estabelecido pelo governante permanece subordinado ao direito natural cristão administrado eclesiasticamente" (HABERMAS 1997a, p. 45).

como pelas relações que a tradição manteve junto ao Poder Judiciário em geral e que Dalmo Dallari bem explica no seu livro "O poder dos juízes"

"Em relação aos juízes esse processo de distanciamento do comum do povo é bem evidente. Ele está presente na linguagem rebuscada e no tratamento cerimonioso, falsamente respeitoso, previsto na própria legislação e que tem efeito real de criar mais temor do que respeito" (DALLARI, 1996, p. 45).

Se compararmos as duas exposições, as explanações desfavoráveis ao aborto argumentam considerando as normas como de reconhecimento intersubjetivo, enquanto que as favoráveis consideram a norma como digna de conhecimento - pode haver boas razões para considerar uma norma vigente socialmente. Ambos conversam no nível convencional mas em estádios diferentes e essa diferença está na forma de agir. Enquanto os primeiros estão orientados para o sucesso e assim os componentes da situação transformam-se em fatos que são valorizados à luz de suas próprias preferências, os seguintes agem orientados pelo entendimento que pode compreender a situação interpretando os fatos relevantes através de pretensões de validade reconhecidas intersubjetivamente.

Destacando o discurso 6, o diálogo desenvolve-se com base no direito positivado onde os juristas, com extremada habilidade hermenêutica, argumentam de formas diferentes sobre os mesmos dispositivos legais. Percebe-se um discurso latente em conflito

\footnotetext{
"Isto pode ser conferido nos discursos 3, 6 e 8 da seção "o aborto".
} 
de poderes. O mais interessante é quando podemos observar a abertura das juristas femininas para uma outra dimensão de experiência moral que trabalha a hermenêutica não exclusivamente em critérios abstratos e gerais positivados na Constituição Federal e Código Penal mas buscam o contexto e o momento da discussão também como força de argumento. Não foram registradas cartas de leitores não-especialistas neste bloco analisado.

Com respeito a este comportamento estamos tratando de um conflito guiado por interesses em agir estratégico, ou seja, parece retratar uma desvalorização de instituições dotadas de uma validez nativa que força uma transformação do equipamento sóciocognitivo do estádio convencional em conceitos imediatamente morais, que resultará na estruturação de novas perspectivas na relação eu-tu (falante-ouvinte) com a introdução de um observador. Desse modo os atores, que a um dado momento se compreendem como participantes na efetuação de uma ação a partir da relação recíproca com um parceiro (estádio convencional), podem sair da ação e observar o objeto como parte integrante de interação (nível pós-convencional).

"As perspectivas tinham que se entrelaçar no quadro interpessoal da interação: a perspectiva do observador foi especificada e vinculada ao papel comunicacional da terceira pessoa, isto é, da pessoa presente mas não envolvida. de maneira análoga, pode-se dizer agora do acordo alcançado discursivamente, que os atores se fiam, no ato de assentimento, na completa reversibilidade de suas relações com todos os outros participantes da argumentação, mas "ao mesmo tempo" atribuem sua tomada de posição, independentemente do consenso factualmente obtido, unicamente à força de convicção de melhor argumento" (HABERMAS 1989, p. 194).

Ainda sobre o judiciário, mesmo quando polemicamente o presidente do Supremo Tribunal Federal Celso de Mello posicionou-se a favor do aborto, as cartas de leitores mantiveram-se na qualidade dos representantes do judiciário citados anteriormente. Somente foram enviadas cartas de pessoas ou representações de advogados.

Já os representantes do legislativo que trataram do assunto no decorrer do período mantiveram discursos favoráveis ao aborto e em nível pós-convencional, quando o interesse da argumentação estava voltado para a questão em si e, portanto, motivados racionalmente pelo outro. A única carta com discurso convencional não focou 
exclusivamente a questão aborto, pois aproveitou a situação para usar de um agir voltado para o sucesso em uma discussão política partidária. Esta tendência para estádio 6, pósconvencional dos integrantes do legislativo e que também será visto, em parte, pelos integrantes do executivo pode ser justificado pela identidade de poder que está mais próxima da diversidade do povo e que, por suas atribuições, dialoga com a população. Este é o ponto diferencial do atribuído ao poder judiciário citado e que se manteve distanciado. $^{72}$

Somente um representante do executivo defendeu o discurso desfavorável ao aborto - o Ministro da Saúde Carlos Albuquerque e isto gerou uma seqüência especial de cartas de leitores. Chama a atenção neste bloco o comportamento dos leitores se comparado aos que conversaram com representantes da Igreja, pois independente da posição favorável ou não ao aborto, os leitores pouco usaram de discursos pré-convencionais sendo na sua maioria discursos convencionais e mesmo pós-convencionais. Desfocados dos princípios religiosos os leitores tendem a argumentar saindo da identidade ${ }^{73}$ natural de distinguir a si mesmo no ambiente sem distinguir entre os objetos físicos e sociais, para uma posição que consegue assimilar os papéis fundamentais de seu ambiente e, portanto, a existência de um sistema de normas. Dessa forma, eles distinguem os papéis diferenciados entre a família, grupos e membros de um sistema organizado. Não dá para inferir que os leitores envolvidos na discussão com os representantes da Igreja também posicionar-se-iam na transição do nível de comportamento pré-convencional e convencional mas a discussão provocada pelo representante do executivo contrário ao aborto demonstrou esta diferença nos comportamentos e que ela se mantém mesmo na presença do máximo representante do Vaticano - o papa João Paulo II. ${ }^{74}$

Destarte, o constatado confirma que afastado de um enunciado de recomendação, formulado na primeira pessoa e que leva a obter um determinado comportamento, os atores transitam entre os três níveis de desenvolvimento e apresentam possibilidades de atingir o nivel pós-convencional. $\dot{E}$ somente neste nível que o agente poderá reconhecer-se em um

\footnotetext{
${ }^{72}$ Isto pode ser conferido nos discursos 3, 7 e 11 da seção "o aborto".

${ }^{73}$ para Habermas o conceito de identidade significa a estrutura simbólica que permite a um sistema de personalidades assegurar continuidade e consistência. Ele distingue três estágios básicos da formação da identidade individual: natural, do papel e do ego. Sobre o assunto ver "Teoría de la acción comunicativa Tomo II Crítica da razão funcionalista" (HABERMAS 1987a, 139-154)

${ }^{74}$ Isto pode ser conferido no discurso 6 da seção "o aborto".
} 
ambiente social e distinguir que algumas formas de vida tradicionalmente estabelecidas podem ser meras convenções.

\section{as drogas}

A seqüência de discursos que envolvem o tema droga define um outro tipo de reação por parte dos leitores. As correspondências apresentaram-se pulverizadas durante o período de investigação tanto quanto a temas abordados tanto como ao número de cartas por assunto. Existe uma tendência maior de cartas assinadas pelos leitores habituais do jornal e por diversas vezes as interpretações afastam-se do próprio tema para tratar de outras questões como violência, o papel da mídia e as condições sociais.

Ao falarem sobre violência, surgem discussões sobre o papel do Estado e da polícia como responsáveis pela solução deste problema. Por um lado os leitores desenvolvem argumentações que tentam coordenar as perspectivas de observador e participante: eles reconhecem uma forma de organização mas o discurso guarda uma certa ingenuidade combinada ainda com uma compreensão intuitiva das regras.

As falas, expressas na primeira pessoa, indicam preferências subjetivas de sentimentos de aversão ou de defesa. Não fica claro a reciprocidade que apresentam entre o mundo objetivo e o subjetivo assim como a passagem de uma interação governada por autoridade para uma interação guiada por normas. Isto pode justificar o comportamento dos leitores em reportar responsabilidades para o Estado, polícia, família e escola como externos a eles. ${ }^{75}$

As duas correspondências identificadas como de representantes da segurança pública $^{76}$ apresentaram comportamentos eqüidistantes. Isto porque enquanto uma trabalha um discurso de autoridade correspondente às expectativas tratadas pelos leitores a outra faz a transição deste discurso de autoridade interiorizado em um arbítrio supra-individual para um de vontade coletiva, portanto usa tanto de um agir estratégico que atua sobre o outro quanto um agir comunicativo motivado racionalmente para uma adesão.

Habermas mostra esta relação quando fala de algumas oposições entre estruturas cognitivas e perspectivas de comportamento.

\footnotetext{
${ }^{75}$ Isto pode ser conferido nos discursos 3: FO-02/02/97,8,13,16,21 FO- 08/06/01 da seção "as drogas".

${ }^{76}$ Isto pode ser conferido nos discursos 8, e 24 da seção "as drogas".
} 
“Analogamente, os conceitos mais complexos da validez normativa $e$ da autonomia surgem dos conceitos mais simples do arbítrio imperativo e da lealdade pessoal ou ainda da orientação em função de prazer/desprazer. $\mathrm{O}$ componente significativo central do conceito elementar em cada caso é descontextualizado e apurado de tal forma que, a partir da perspectiva conceptual do estádio superior, o conceito superado é estilizado em um contraconceito. Assim, por exemplo, o exercício da autoridade da pessoa de referência transforma-se no estádio seguinte, no mero arbítrio, que contrasta com a expressão legítima da vontade; as lealdades pessoais ou orientações em função do prazer/desprazer transformam-se em meras inclinações, que contrastam com deveres" (HABERMAS 1989, p. 203).

Apesar de neste período existirem discussões sobre despenalização e descriminalização do uso de drogas, não foi este o mote para levar os leitores ao discurso. Mesmo a proposta do PL 2684/97 $7^{77}$, que cria um momento de rompimento de normas, não estimulou situações de discurso.

Os artigos sobre a descriminalização das drogas receberam atenção em três discursos. ${ }^{78}$ Dois artigos usaram de exemplos particularizados para argumentar sobre o tema. Marcelo Coelho confessou o uso drogas enquanto Marcos Segre lançou mão de um argumento hipotético pungente na mesma situação particularizada - todas as pessoas passariam a fazer uso de drogas, proposições potencialmente reflexivas aos leitores. $\mathrm{Na}$ primeira situação estes refletiram papéis de falante e ouvinte sem a identificação de uma terceira pessoa e simplesmente chamaram o autor para se colocar nas situações de conflitos provocadas pela droga no meio, ou seja, em situações particularizadas. Já o discurso dos que conversaram com Segre mantiveram-se no nível pré-convencional, argumentando ou em base de estruturas do falante ou no conceito de autoridade. O terceiro artigo justificou sua posição contra a discriminalização chamando a escola para atuar como educadora mas num papel de polícia: usa do agir estratégico para ensejar a continuação desejada de uma interação. As respostas tiveram tanto reflexões para um agir comunicativo como em exigências de um sistema atuando na situação o que sugere decisão em escolha racional motivada em auto-interesse.

\footnotetext{
${ }^{77}$ uma única carta que tratou deste assunto refere ralações entre a folha e o relator de parecer do mesmo.

${ }^{78}$ Isto pode ser conferido nos discursos 15,21 e 25 da seção “as drogas”.
} 
Ainda sobre o espaço da escola, os leitores o identificam como uma zona de tensão e as falas ou coincidem com a do parágrafo anterior ou manifestam-se em tentar coordenar o agir em propostas educacionais que levem as pessoas a se entender sobre as drogas em ações mutuamente compartidas. ${ }^{79}$

A análise das duas correspondências relacionadas ao discurso 20 , comentários sobre o filme "Traffic", mostra como uma proposta ampliada permite reflexões na perspectiva social de princípios e, com a interação das estruturas de perspectivas do falante e do mundo provoca uma resposta de comportamento socialmente generalizado em sistemas de normas na legitimidade de uma vontade coletiva. Observa-se na segunda a distinção entre validez ideal sem observar a validez social; o leitor percebe o dano de um drogado na sociedade mas no sentido utilitarista: o maior bem para o maior número de pessoas sem associar o aspecto mais amplo da discussão concernente ao uso da droga pelo sujeito. ${ }^{80}$

Chama atenção a forma singular de tratar este assunto por alguns leitores, pois atitudes benevolentes e discriminatórias foram bastante freqüentes para tratar de situações de conflito. ${ }^{81}$ Os leitores nesta situação agiram orientados para o sucesso

“ (...) isto é, para as conseqüências do seu agir, eles tentam alcançar objetivos de sua ação influindo externamente, por meio de armas ou bens ou seduções, sobre a definição da situação ou sobre decisões ou motivos do adversário" (HABERMAS 1989, p. 164).

A discussão travada com a mídia a respeito da veiculação de informações e orientações sobre as drogas também sugere um comportamento diferenciado. Esta se dá nos modelos de enfoques sobre o tema e a influência que se pode gerar principalmente quando referenciado à filhos e adolescentes. Os leitores buscam por uma interpretação pública de suas experiências e interesses sociais. Dessa maneira, as abordagens dadas pelo jornal são avaliadas em suas formas e julgadas em termos de resultados sobre convicções e/ou persuasões, ou seja, que tipo de interações estas reportagens ou artigos e mesmo imagens, podem ser realizadas. ${ }^{82}$

\footnotetext{
${ }^{79}$ Isto pode ser conferido nos discursos 4, 5, 9, 11,24 e 25 da seção "as drogas".

${ }^{80}$ este aspecto é referido na reportagem geradora quando discute o uso de cigarro e o stress vivido pelos estudantes da área de biológicas.

${ }^{81}$ Isto pode ser conferido nos discursos 1, 3, 6 e 17 da seção "as drogas".

${ }^{82}$ Isto pode ser conferido nos discursos 2,10,14,22 e 23 da seção "as drogas".
} 
Dentre os artigos a discutir a mídia, destaco o discurso 10 que trata da apologia da droga. É interessante observar o debate sobre a liberdade de expressão, pois na realidade a maioria das cartas referidas tratam do entrelaçamento entre liberdade de expressão e opinião e a apologia da droga, ou ainda, como separar artigos e reportagens orientadoras sobre o assunto e publicidade e ensinamento do uso delas. As reações dos leitores variam em função do conceito de autoridade e interação a semelhança do casos relacionados à polícia. Aqui a discussão pondera inclusive sobre validez ideal e validez social da questão.

Contrariamente, os artigos e comentários feitos por especialistas médicos não se incluem nesta dúvida dos leitores, sugerindo um relativo grau de convicção depositado por eles na medida que são reconhecidos como seus representantes.

As situações envolvendo a discussão dos instrumentos legais mantiveram o mesmo comportamento de linguagem observado na seção "o aborto". Persiste o discurso encetado entre juristas diante da força legal de norma envolvida para solução do caso versus o uso de assentimento motivado racionalmente como argumento para aproximar a validez ideal da social. $^{83}$

\section{a eutanásia}

As questões refletidas pelos leitores para o tema eutanásia apresentaram-se sob duas perspectivas: social e religiosa.

A perspectiva social $^{84}$ é argumentada com base em princípios de igualdade de direitos humanos. O leitor favorável a eutanásia contextualiza a amplitude deste direito e levanta uma nova pretensão de validez: devemos pensar em uma morte digna antes de obtermos uma vida digna?

$\mathrm{O}$ outro discurso, ${ }^{85} \mathrm{em}$ perspectiva religiosa, argumenta sob princípios transcendentais. Assim, contrário a eutanásia, desenvolve suas reflexões sobre o excesso terapêutico e a melhoria da qualidade da morte.

São duas questões diferenciadas, uma com fundamentos de validez na perspectiva de Deus, o sagrado e a outra na perspectiva do homem, o profano.

\footnotetext{
${ }^{83}$ Isto pode ser conferido nos discursos 1 e 10 da seção "as drogas".

${ }^{84}$ Isto pode ser conferido no discurso 2 da seção "a eutanásia".

${ }^{85}$ Isto pode ser conferido no discurso 2 da seção "a eutanásia".
} 
"Decerto a atividade do entendimento gera liberdade subjetiva e reflexão e é forte o suficiente para enterrar a força a tradição religiosa. No passado a religião era em essência uma garantia da integração da ética da vida social e no presente a vida religiosa foi abalada pelo Iluminismo" (HABERMAS 2001, p. 173).

\section{a doação}

O tema doação concentrou maior desentendimento. Em sua maioria, as pessoas se posicionaram contrárias à lei e muitas delas por não compreender o diferencial entre os conceitos: compulsório, obrigatório de presumido. Também falharam em pretensão de validez os argumentos que definiram a lei como autoritária, ou mesmo entenderam ser o instrumento legal uma medida provisória dado que o projeto de lei foi aprovado pelo Congresso Nacional e sancionado pela presidência da República. ${ }^{86}$

Os argumento favoráveis à lei baseiam-se em atitudes benevolentes ou religiosas de amor ao próximo. ${ }^{87} \mathrm{~A}$ maioria dos argumentos desfavoráveis trouxeram reflexões enquadradas no nível convencional. É interessante notar que neste nível a pessoa começa a reconstruir seus conceitos fundamentais, seu entendimento de normas e assume os papeis comunicacionais de falante, destinatário e pessoa presente (papéis que correspondem às perspectivas dos participantes de primeira e segunda pessoa, assim como a de um observador). As convenções anteriores são revistas e necessitam de justificativas e assim, com relação às normas ele começa a distinguir entre aquelas em vigor numa sociedade e as reconhecidas como válidas; aqui ele passa a ter também uma nova perspectiva de mundo.

Isto sugere o descompasso do entendimento da lei para os participantes que se recusam a aceitá-la. Seus argumentos ganham força quando defendem a familia ${ }^{88}$ no

\footnotetext{
${ }^{86}$ Isto pode ser conferido nos discursos 1, 4, 7 e 8 da seção "a doação presumida".

${ }^{87}$ Isto pode ser conferido nos discursos $1,3,7$ da seção "a doação presumida".

${ }^{88}$ Frente à rejeição pela população da obrigatoriedade imposta pela lei, diversas instituiçðes médicas começaram a se pronunciar com respeito ao assunto, orientando a categoria que, ao arrepio da lei, somente tirassem órgãos de "pacientes" após a autorização da familia. Esta atitude demonstra que uma lei que entra em conflito, se analisada na presunção de conceitos éticos universais pode levar as pessoas a agir pelo consenso.
} 
processo de decisão da doação em caso de morte, carregam de responsabilidade o Estado como externos a ele ao mesmo tempo que a autoridade e a lei é dada por ele, ou seja, os discursos identificados transparecem justamente a transição do estádio 3 para o 4 quando as interações passam a serem guiadas por normas e o conceito de autoridade é interiorizado da vontade coletiva, portanto da obediência por lealdade para a obediência pela legitimidade. ${ }^{89}$

Outro aspecto abordado relaciona-se aos grupos médicos de transplante e à fila única. ${ }^{90}$ Os leitores frente às denúncias de grupos interessados em obter um maior número de órgãos também se colocam na posição anterior em delegar ao Estado o dever de solucionar a questão.

O referencial de autoridade confiado aos especialistas médicos - donos de um saber mágico e respeitado, enquadrinha-se em uma nova dimensão ao tratar desta questão. Os atores olham com reserva o pretenso discurso médico ao tratar da distribuição dos órgãos. A verdade não mais aceita como um imperativo ou resultado de uma lealdade de uma pessoa de referência é questionada quanto a sua validez.

\section{a clonagem}

O tema clonagem, pouco discutido no decorrer dos anos pesquisados não centrou, por parte dos leitores, observações quanto ao processo de decisão ética sobre o clonar ou não. O que se destaca são argumentos que transcendem o ato em si para o receio da interferência do homem ou do homem cientista neste processo ${ }^{91}$. Dessa maneira, na sequiência das cartas encontramos duas, já no fim do período, que opinam da necessidade de legislação para cuidar deste assunto. É interessante ver que para este período, a clonagem discutida é a terapêutica e, como ela pode salvar vidas, em especial com o uso de células-tronco de embriões, torna-se necessário criar um instrumento legal para coibir o homem, o homem cientista e o homem empresário.

Mas para este aspecto entra em discussão novamente as questões religiosas ${ }^{92}$ já vistas na seção que trata do aborto, pairando a mesma pergunta: embriões têm vida? A

\footnotetext{
${ }^{89}$ Isto pode ser conferido nos discursos $3,, 5,6,8,10$ e 11 da seção "a doação presumida".

${ }^{90}$ Isto pode ser conferido nos discursos 1,7 e 9 da seção "a doação presumida".

${ }^{91}$ Isto pode ser conferido nos discursos 1, 3 e 4 da seção "a clonagem".

${ }^{92}$ Isto pode ser conferido no discurso 2 da seção "a clonagem".
} 
complexidade em elaborar uma legislação para abortos terapêuticos também envolve os princípios religiosos $\mathrm{e}$ as questões de direito à vida. ${ }^{93}$ Tratando sobre o assunto da normalização, Habermas refere

"O caminho para as inovações é aberto não apenas pelos interesses dos pesquisadores nas suas reputações e tampouco apenas pelos interesses dos fabricantes envolvidos no sucesso econômico. As novas ofertas aparentemente vão ao encontro dos interesses dos compradores. $\mathrm{E}$ esses interesses freqüentemente são tão convincentes que com o passar do tempo a preocupação moral empalidece. A diminuição do sofrimento não seria ela mesma um argumento moral?'(HABERMAS 2001, p. 209).

\section{a dupla porta}

O tema dupla porta foi pouco dialogado entre os leitores. A situação concreta deste discurso reside em um rompimento de um modelo tradicional: hospitais-escola ligados ao sistema de saúde passarem atender e receber de pacientes particulares e/ou conveniados. $\mathrm{O}$ argumento colocado para exame de validade é se com este rompimento do modelo anterior haverá perda de igualdade de atendimento para os pacientes provenientes do SUS.

O debate em questão não envolve os pacientes, ele é discutido por representantes médicos dos hospitais e associações. Isto de certa forma justifica a ausência de discursos pré-convencionais e o exame de pretensão de validez se dá em base de princípios - a igualdade de atendimento. ${ }^{94}$

O debate desenvolve-se na transição entre uma representação de justiça dada em conformidade ao sistema de normas existente orientado em função de princípios de justiça. A representação de justiça transita de um discurso anuído em um sistema de normas para um reportado a princípios éticos, o resultante: um instrumento legal para a sua permissão.

"Además, retrospectivamente me parece claro que "U" [princípio de universalização LMP] há operacionalizado, ante todo, un princípio discursivo más amplio en relación com una cuestión especial, a saber, la moral. El

\footnotetext{
${ }^{93}$ Isto pode ser conferido nos discursos 2 e 4 da seção "a clonagem".

${ }^{94}$ Isto pode ser conferido nos discursos 1 e 2 da seção "a dupla porta".
} 
principio discursivo se puede operacionalizar también para cuestiones de otro tipo, así, por ejemplo, para la deliberación de um legislador o para los discursos juridicos" (HABERMAS 1999, p. 78).

\section{o plano de saúde}

Existem três instantes essenciais nesta discussão: a denúncia de uma dupla cobrança dentro do SUS, a necessidade de regulamentação da legislação relativa aos contratos de serviços de saúde e o resultado de um discurso comunicativo concluído em consenso.

A prática de uma segunda cobrança de um mesmo paciente dentro dos hospitais conveniados ou não do SUS, como também o controle da aplicação de recursos, manifestou-se entre algumas correspondências aqui tratadas. ${ }^{95} \mathrm{Na}$ leitura das cartas é perceptível a encenação que oculta outra realidade, pois este procedimento estabeleceu-se latente na prática cotidiana de alguns hospitais. A justificativa é dada em função dos baixos valores para pagamentos de procedimentos na tabela SUS.

Os processos comunicativos quando sistematicamente distorcidos expressam um potencial conflito que não pode ser resolvido e se estabelece não manifesto nas ações do cotidiano na identidade de pessoas e grupos (no que refere ao estabelecimento dos níveis morais).

"Si trata, pues, de conflitos que ni afloran abiertamente, ni se resuelven consensualmente, sino que, por sí decirlo, siguen humeando bajo una apariencia de acción consensual, con el conseguiente efecto de distorsión de la comunicación" (HABERMAS 1994, p. 215-216).

Isto assim se mantém até que seja reconhecido, nesse momento, ele se transforma em um reconhecimento real através de sua otimização conforme máximas de ação racional com respeito aos fins que é o curso dado para esta questão.

$\mathrm{O}$ segundo instante gira em torno de uma premissa básica: relação público $\mathrm{e}$ privado. Portanto ele está permeado por parâmetros de custo e beneficio e agir estratégico

\footnotetext{
${ }^{95}$ Isto pode ser conferido nos discursos 2 e 6 da seção "o plano de saúde".
} 
para o sucesso que coloca o homem em uma condição restrita distanciado do complexo mundo de interações. Inserido em uma possível crítica ao comportamento utilitarista do homo economicus, o agir comunicativo permite a introdução do conceito de homem dentro do mundo da vida dos atores sociais

"Para além do revisionismo e da interdisciplinaridade, a única alternativa que se coloca é a construção de um novo programa de pesquisa, onde o novo núcleo rígido comporte um conceito de homem que, dentro do possivel, aproxime a ciència do mundo da vida dos atores sociais. Nesse sentido, uma alternativa que se mostra bastante promissora é a linha de pesquisa desenvolvida por Habermas na construção de uma teoria do agir comunicativo.

Essa teoria contrapõe a orientação para o entendimento mútuo com a orientação para o sucesso. Nesta, os atores buscam o sucesso, isto é, almejam objetivos por meios estratégicos que são determinados pelos cálculos de ganho egocêntrico. Já no entendimento mútuo, os atores tratam de harmonizar seus planos de ação tendo em vista um acordo existente sobre a situação e suas conseqüências. Esse acordo depende do assentimento racionalmente motivado ao conteúdo de um proferimento, isto é, seus planos de ação não precisam ser reduzidos ao agir teleológico" (VALENTIN 1994, p. 65).

Dessa forma, os leitores, na sua maioria, tratam a questão discutindo a validez social e ideal reivindicando direitos originários baseados no cálculo racional de utilidade geral. $^{96} \mathrm{O}$ conflito entre as correspondências está permeado de um lado pela "frieza" do referenciar à figura do paciente como um produto ou seja da influência recíproca de atores orientados pelo sucesso e por outro, de sujeitos orientados para o entendimento mútuo.

Como coloca Habermas ao discutir a integração social através do agir comunicativo, este impõe limitações pragmáticas aos sujeitos desejosos de utilizar as forças aglutinantes de uma linguagem, sentem-se obrigados a sair do egocentrismo e a se colocar sob critérios públicos da racionalidade do entendimento propiciando o surgimento de ações estratégicas. Ainda segundo ele, na presença de conflito, os que agem

\footnotetext{
${ }^{96}$ Isto pode ser conferido nos discursos 1, 3, 4, e 5 da seção "plano de saúde".
} 
comunicativamente encontram-se perante a alternativa de suspenderem a comunicação ou de agirem estrategicamente - de protelarem ou tentarem decidir um conflito não solucionado.

"Mesmo assim, o que age estrategicamente mantém o mundo da vida como um pano de fundo; porém neutraliza-o em sua função de coordenação da ação. Ele não fornece mais um adiantamento de consenso, porque o que age estrategicamente vê os dados institucionais e os outros participantes da interação apenas como fatos sociais" (HABERMAS 1997, p. 46).

A suspensão da comunicação pode ser observada em uma correspondência que denúncia uma fala inverídica do argumento custo $\mathrm{x}$ beneficio (falha de pretensão de validez) dita por representante do setor privado ${ }^{97}$. O consenso pode ser visto em outra que relata o resultado de um agir comunicativo na solução de questões relativas aos planos de saúde- a aproximação da validez ideal com a validez social do estádio 6 , nível pósconvencional. ${ }^{98}$ Através da formação da opinião e da vontade é possível conseguir a legitimidade de um direito mesmo em meio ao pluralismo de concepções de mundo e este pode ser analisado a partir de uma teoria do discurso.

“ À luz desse princípio do discurso, os sujeitos examinam quais são os direito que eles deveriam conceder uns aos outros. Enquanto sujeitos do direito, ele têm que ancorar esta prática da autolegislação no medium do próprio direito; eles têm que institucionalizar juridicamente os próprios pressupostos comunicativos e os procedimentos de um processo de formação da opinião e da vontade, no qual é possivel aplicar o princípio do discurso" (HABERMAS 1997a, p. 319).

\footnotetext{
${ }^{97}$ Isto pode ser conferido no discurso 6 da seção "o plano de saúde".

${ }^{98}$ Isto pode ser conferido no discurso 7 da seção "o plano de saúde".
} 


\section{CONSIDERAÇÕES}

O processo de comunicação é o meio de socialização dos seres humanos. $O$ ato de comunicar-se manifesta sentimentos e valores dando existência à emancipação e à concretização do direito das pessoas. Por outro lado, a ética refere-se ao bem do indivíduo e da comunidade. Esta é a dimensão do avizinhamento da ética discursiva e da ética em saúde.

"A ética do discurso vai inserir-se, então, no círculo das ciências reconstrutivas que têm a ver com os fundamentos racionais do conhecer do falar e do agir. Se não aspirarmos mais ao fundamentalismo da filosofia transcendental tradicional, conseguiremos novas possibilidades de controle para a ética do Discurso. Ela poderá, em concorrência com outras éticas, ser mobilizada para a descrição de representações morais e jurídicas empiricamente constatadas, ela poderá ser inserida em teorias do desenvolvimento da consciência moral e jurídica, tanto no plano do desenvolvimento sociocultural quanto no plano da ontogênese, e assim, tornarse acessivel a um controle indireto" (HABERMAS 1989, p. 121).

Segue-se que as questões de justiça - como refere Habermas - já respondidas desde sempre, diante do olhar reflexivo de um participante do Discurso provoca a decomposição do mundo social em convenções carentes de justificação. E ainda, a forma de socialização determinada pela comunicação e acompanhada da polarização da prática social faz com que os modelos dados distanciem-se dos interesses dos diversos grupos.

Este é o contexto histórico que percebemos a inserção das correspondências dos leitores aqui transcritas onde

"o acervo factual de normas tradicionais divide-se em fatos sociais, por um lado, e normas, por outro lado - estas perderam o respaldo das evidências do mundo da vida e precisam ser justificadas à luz de princípios. É assim que a "orientação em função de princípios de justiça" e, em última instância, em função do processo do "Discurso em torno da fundamentação de normas" resulta da inevitável moralização de um mundo social que se tornou questionável" (HABERMAS 1989, p. 199). 
Em consonância com isso, o estudo demonstrou que a população investigada cumpriu o mínimo de condições para a situação da fala, podendo intervir e replicar a qualquer momento, com igual oportunidade de fazer interpretações, afirmações, recomendações, explicações, justificações e de problematizar questões.

As temáticas e criticas encontradas puderam ser cotejadas nos três níveis comunicativos - pré-convencional, convencional e pós-convencional. Assim, o suposto de que qualquer vida sociocultural está pelo menos implicitamente orientada para um agir comunicativo através de meios argumentativos - por mais rudimentar que tenha sido o desenvolvimento das formas de argumentação e por mais pobre que tenha sido a institucionalização dos processos discursivos do entendimento mútuo, ${ }^{99}$ mostrou-se suficiente nesta análise.

Outrossim, identificou-se neste estudo a pluralidade de formas culturais e formas de vida e sua multiplicidade de manifestações encontradas tanto para situações de fala comunicativamente distorcidas e coativas assim como simétricas em oportunidades de eleger e executar seus atos de fala.

Além disso, independente do resultado dos discursos, as reconstruções de situações de fala, que per se produzem o mundo social e as identidades do grupo, permitiram detectar que as interações simples dos níveis pré-convencional e convencional atraíram discursos semelhantes, reproduzidos nas mesmas estruturas e dissolvidos em conversações estereotipadas ou em diálogos em si mesmo.

Por outro lado, os discursos pós-convencionais despertaram interlocutores superando as interações regulares dos estádios anteriores transformando-os em agentes reflexivos inseridos no contexto do mundo da vida

Segue-se que a responsabilidade contida em uma pretensão de validez é indispensável aos participantes e, em particular aos depositários de conhecimento, para

\footnotetext{
99 A presença desta pluralidade contrapõe o que refere a Prof. Dra. Iara Guazelli em seu artigo $A$ especificidade do fato moral Em Habermas: O uso moral da Razão Prática, quando diz: "Segundo o autor (Habermas), os três usos da razão prática, realizam ou são resultado de três estádios de desenvolvimento moral os quais, por sua vez, estão relacionados a três estádios de desenvolvimento psico-genético. O que é plenamente moral encontra-se no final, no último estágio. A consequeência espantosa desta ligação, para a teoria, é que o agir estratégico, que, sem dúvida, segundo o autor, é o predominante em nossa sociedade e a determina, não pode ser dissecado, analisado ou medido pela teoria porque "escapa" por assim dizer, ao estatuto moral. Do ponto de vista psico-genético, ele é característico de um pré-adolescente que a rigor, ainda não percebe a dimensão moral e nem mesmo a dimensão ética de suas ações. Ora, todos aqueles que controlam o sistema social no qual estamos inseridos e nós mesmos enquanto membros participantes deste sistema não podemos nos pensar como pré-adolescentes imaturos, pois que assumimos nossas posições como adultos" Disponível em: www.sedes.org.br/Centros/habermas.htm. Acesso em: 1 de maio de 2002.
} 
permitir que os conteúdos dos sujeitos cognoscentes sejam trazidos à consciência, diferenciados e reconstruídos em estádios imediatamente superior para enfim recolocar em movimento a cooperação paralisada estendo-a à solidariedade.

Disso deriva a convicção que a proposta de inserir a ética do discurso nas atuais discussões da ética em saúde demonstrou-se promissora para a descrição de representações morais e jurídicas nos diversos estágios de desenvolvimento humano e sociocultural, ou seja, nas diferentes formas de vida e, nesses termos, as suas condições de realização.

Ainda a esse respeito comungo com Ruy Fausto quando diz em entrevista dada à Folha de São Paulo:

"Hoje no Brasil aparece por parte de alguns (penso em particular no meu amigo [e professor de filosofia da USP] Paulo Eduardo Arantes) a tentação de tomar um caminho radicalmente crítico, eu diria antifilosófico. Creio que isso é uma ilusão que pode levar a maus resultados - inclusive no plano da política. O caminho de Adorno é, a meu ver, o mais fecundo. Penso entretanto que, para além de Frankfurt, seria preciso repensar a ética. E é o fato de se passar por cima desse problema o que mais me assusta - mas não só - nas tendências antifilosóficas que surgem no Brasil" (FAUSTO 2002). ${ }^{100}$

A filosofia não conhece o próprio conhecimento. Não é uma voz na primeira pessoa que estabelece condições e restrições a serem ouvidas pelos demais participantes de um diálogo como em um discurso fundamentalista. Seu papel é o de intérprete das práticas comunicativas cotidianas.

"Enquanto a filosofia moral se colocar a tarefa de contribuir para o aclaramento das instituições cotidianas adquiridas no curso da socialização, ela terá que partir pelo menos virtualmente da atitude dos participantes da prática comunicativa cotidiana" (HABERMAS 1989, p. 67).

${ }^{100}$ FAUSTO R. Marx Contra Marx. Folha de São Paulo, São Paulo, 09 mai 2002 Disponivel em <URL:http://www.uol.com.br/. Acesso em: [09 mai 2001]. 


\section{REFERÊNCIAS BIBLIOGRÁFICAS}

\section{Fontes primárias}

JORNAL FOLHA DE SÃO PAULO. Arquivo da Folha de São Paulo. São Paulo, 2001. Disponivel em: <URL:http://www.uol.com.br/bibliot/arqfolha.htm.

JORNAL O ESTADO DE SÃO PAULO. Arquivo de O Estado de São Paulo. São Paulo, 2001. Disponível em: <URL:http://www.estadao.com.br/busca

\section{Bibliografia}

Andrade, C.J. A contribuição de Habermas para a hermenêutica juridica Revista de Estudos Jurídicos 1998 6(a.3):109-124.

Anjos MF. Bioética: Abrangência e Dinamismo. O Mundo da Saúde 1997; 21(1):4-12.

Apel K-O. Ética do discurso como ética da responsabilidade. Cadernos de Tradução $19983: 8-37$.

Arendt, A. A condição humana. Rio de Janeiro: Forense Universitária; 2000.

Bertomeu M. J. Implicações filosóficas na reflexão, discurso e ação dos comitês de ética. Bioética 1995; 3(1):21-27.

Boal A. Teatro como arte marcial. Folha de São Paulo, São Paulo, $29 \operatorname{dez} 2000$. Disponivel em: <URL:http://www.uol.com.br/. [2000 dez 30].

Calhoun C. Habermas and the Public Sphere. 3th print Cambridge: MIT Press; 1994.

Clotet J. Bioética como ética aplicada e genética. Bioética 1997; 5(2) 5: 73-183.

Cohen J. L. E Arato A. Esfera pública y sociedad civil. Metapolítica 1999; 3(9):37-55. Disponível em:<URL: http//www.cepcom.commx/metapolitica/. [2003 fev 8].

Costa S. La esfera pública y las mediaciones entre cultura y política: el caso de Brasil. Metapolítica 1999;3(9):95-107. Disponivel em<URL: http//www.copoomoommx/metapolitical. [2003 fev 8].

Cucurella M.B. La opinión pública en Habermas. Anàlisi 2001; 26: 51-70.

Dallari, D.A. O poder dos juízes. São Paulo: Saraiva; 1996.

Datafolha Instituto de Pesquisa Para 73\%, FHC deve aprovar lei que obriga hospitais a realizar cirurgias emt caso de estupro ou de risco para a mãe: paulistano apóia projeto 
do aborto legal. Folha de São Paulo, São Paulo, 28 de dezembro de 2000. Disponivel em: <URL:http://www.uol.com.br/. [1997 dez 28].

Demo P. Pesquisa e construção de conhecimento: metodologia científica no caminho de Habermas. Rio de Janeiro: Tempo Brasileiro; 1994.

Dworkin RM. Life's dominion: an argument about abortion, euthanasia, and individual freedom. New York: Vintage Books; 1994, p. ix-xiii.

Guazelli I. A Especificidade do fato moral em Habermas: o uso da razão prática. Disponivel em: www.sedes.org.br/Centros/habermas.htm. [1 mai 2002].

Geuss R. Teoria critica: Habermas e a Escola de Frankfurt. São Paulo: Papirus; 1988.

Fausto R. Marx Contra Marx. Folha de São Paulo, São Paulo, 09 mai 2002 Disponível em <URL:http://www.uol.com.brl. Acesso em: 09 mai 2002.

Ferraz FC. A questão da autonomia e a bioética. Bioética 2001; 9(1):73-98.

Fortes PAC. Ética e saúde: questões éticas, deontológicas e legais, tomadas de decisões, autonomia e direitos do paciente, estudos de casos. São Paulo: EPU; 1998.

Fortes PAC. A ética do controle social na saúde e os conselhos de saúde. Bioética 1997, 5(1):71-76.

Freitag B., Rouanet S.P. organizadores. Habermas: sociologia. $2^{\mathrm{a}}$ ed. São Paulo: Ática; 1990.

Folha de São Paulo Manual Geral da redação $2^{\mathrm{a}}$ ed. São Paulo; 1987.

Garrafa V. O mercado de estruturas humanas. Bioética 1993; 1(2):115-23).

Garrafa V. Bioética e ciência - até onde avançar sem agredir. In: Costa SIF; Garrafa V; Oselka G. Iniciação à Bioética. Brasília: Conselho Federal de Medicina, 1998, p. 99-110. Garrafa V , Porto D. Bioética, poder e justiça: por uma ética da intervenção $O$ Mundo da Saúde 2002;26(1):6-15.

Geuss R. Teoria crítica: Habermas e a escola de Frankfurt. São Paulo: Papirus; 1988. Habermas J. A Constelação pós-nacional: ensaios políticos. São Paulo: Littera Mundi; 2001.

Habermas J. Aclaraciones a la ética del discurso. Madrid : Trotta; 2000a.

Habermas J. Más allá del Estado nacional. México: Fondo de Cultura Económica; 2000b, p. 149-175.

Habermas J. La inclusión del otro. Barcelona: Paidós; 1999, p. 29-78. 
Habermas J. Direito e Democracia: entre facticidade e validez. Rio de Janeiro: Tempo Brasileiro, 1997. v1.

Habermas J. Direito e Democracia: entre facticidade e validez. Rio de Janeiro: Tempo Brasileiro, 1997. v2.

HABERMAS J. A ineficácia da dialética. Folha de São Paulo, São Paulo, 1997 out. 26; Disponivel em <URL:http://www.uol.com.br/. Acesso em: [20 jun. 2001].

Habermas J. Teoría de la acción comunicativa: complementos y estudios previos. $2^{\mathrm{a}}$ ed. Madrid: Catedra; 1994.

Habermas J. Critical Theory and the Frankfurt University In: Dews P. editor Autonomy \& Solidarity: interviews with Jürgen Habermas $2^{\text {nd }}$ ed. New York: Verso; 1992.

Habermas. J. Escritos sobre moralidad y eticidad. Barcelona: Paidós; 1991.

Habermas J. Teoría y Praxis: estudios de filosofia social. $2^{\mathrm{a}}$ ed. Madrid: Tecnos; 1990 , $\mathrm{p}$. 13-48.

Habermas J. Consciência Moral e agir comunicativo Rio de Janeiro: Tempo Brasileiro; 1989.

Habermas J. Teoría de la acción comunicativa Tomo I Racionalidad de ação e racionalização social. $2^{\mathrm{a}}$ ed. Madrid: Taurus; 1988.

Habermas J. Teoría de la acción comunicativa Tomo II Crítica da razão funcionalista $2^{\mathrm{a}}$ ed. Madrid: Taurus; 1988.

Habermas J. Um perfil filosófico-político: entrevista com Jüergen Habermas. Novos Estudos 1987; 18:77-102.

Habermas J. Conhecimento e interesse, com um novo prefácio. Rio de Janeiro: Guanabara; 1987.

Habermas J. Mudança estrutural da esfera pública: investigação quanto a uma categoria da sociedade burguesa. Rio de Janeiro: Tempo Brasileiro; 1984.

Habermas J. Conhecimento e interesse. In: Textos Escolhidos Walter Benjamin, Max Hokheimer, Theodor W. Adorno, Jürgen Habermas $2^{\mathrm{a}}$ ed. São Paulo: Abril Cultural; 1983. p. $301-312$.

Hughes JJ. O futuro da morte. Folha de São Paulo, São Paulo, 04 nov 2001. Disponível em: <URL: http://www.uol.com.br/. [2001 nov 16].

Kant I. Fundamentação da metafísica dos costumes. Lisboa : Edições 70; 1997. 
Martin LM. Ética em pesquisa: uma perspectiva brasileira. O Mundo da Saúde 2002 26(1):85-100 jan./mar.

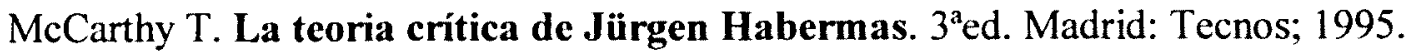

Minayo M.C.S. O desafio do conhecimento. São Paulo-Rio de Janeiro: Hucitec; 1992.

Neves MCP. Fundamentação antropológica da bioética. Bioética 1996; 4(1):07-1.

Nunes FA. Apresentação. IESUS 1996, V(2 supl. 3):3.

O Estado de São Paulo Manual de redação e estilo. São Paulo: Martins Fontes; 1990,

Oselka G, Garrafa V, Diniz D. Saúde pública, bioética e equidade. Bioética 1997; 5(1):27$33)$.

Pessini L. Barchifontaine CP. Bioética: do principialismo à busca de uma perspectiva Latino-americana, In: Costa, S.I.F; Garrafa,V; Oselka, G. Iniciação à Bioética. Brasília: Conselho Federal de Medicina; 1998. p. 81-98.

Rawls J. Uma teoria da justiça, São Paulo: Martins Fontes; 1997. p. 3-200.

Segre M, Silva FL, Schramm FR. O contexto histórico, semântico e filosófico do princípio de autonomia. Bioética 1998, 6(1):15-23.

Siebeneicheler F.B. Jürgen Habermas: razão comunicativa e emancipação. $3^{\mathrm{a}}$ ed. Rio de Janeiro: Tempo Brasileiro; 1994.

Silva FL. Breve panorama histórico da ética. Bioética 1993; 1(1):7-11.

Stieltjes C. Jürgen Habermas: a desconstrução de uma teoria. São Paulo: Germinal; 2001.

Thompson J. B. A. La teoria de la esfera pública. Voces y Culturas 1996; 10 [21 screens] Disponível em:<URL: http:/www.nombrefalso.comar/materias/apuntes/pdftthompson.pdf. [2003 fev 5].

Valentin A. Uma crítica à ciência econômica positiva: considerações a partir do núcleo rígido do programa de pesquisa neoclássico. São Paulo: 1994. [Monografia Bacharelado em Ciências Econômicas - Faculdade de Economia, Administração e Contabilidade da USP].

White S.K. Razão, justiça e modernidade: a obra recente de Jürgen Habermas. São Paulo : Icone; 1995. 


\section{Universidade de São Paulo \\ Faculdade de Saúde Pública \\ COMITÊ DE ÉTICA EM PESQUISA - COEP}

Av. Dr. Arnaldo, 715 - CEP 01246-904 - São Paulo - Brasil

Telefones: (55-11) 3066- 7734 - fone/fax (55-11) 3064 -7314 -

\section{Of.COEP/206/02}

01 de julho de 2002

Pelo presente, informo que o Comitê de Ética em Pesquisa da Faculdade de Saúde Pública da Universidade de São Paulo-COEP, analisou, o Protocolo de Pesquisa n. ${ }^{\circ} 829$, intitulado: "ÉTICA DO DISCURSO: UM OLHAR PARA O OUTRO NAS QUESTÕES DE SAÚDE”, apresentado pela pesquisadora Livia Maria Pedalini, e por não se tratar de pesquisa envolvendo seres humanos, não há necessidade de parecer deste Comitê.

Atenciosamente,

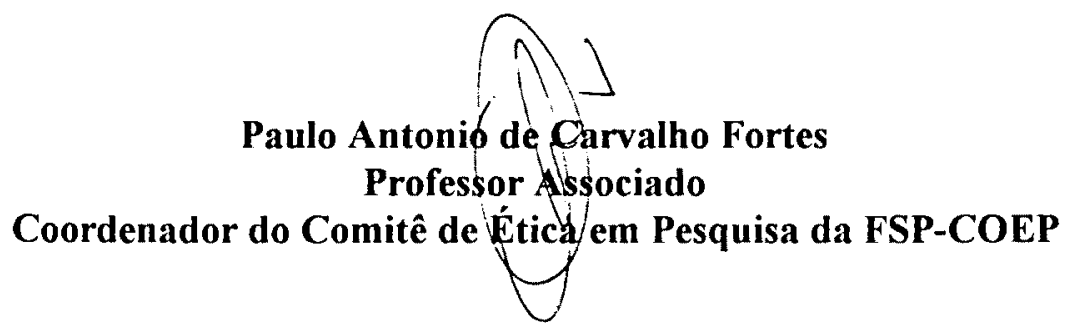

